$$
\text { UNIVESIDADE DE SÃO PAULO }
$$

FACULDADE DE FILOSOFIA, LETRAS E CIÊNCIAS HUMANAS DEPARTAMENTO DE TEORIA LITERÁRIA E LITERATURA COMPARADA PROGRAMA DE PÓS-GRADUAÇÃO EM TEORIA LITERÁRIA E LITERATURA COMPARADA

Nedilson César Rodrigues dos Santos

ADEQUAÇÃO E IMPASSES DE UMA NARRATIVA:

UMA LEITURA DE A HORA DOS RUMINANTES, DE JOSÉ J. VEIGA

SÃO PAULO 
Nedilson César Rodrigues dos Santos

\section{ADEQUAÇÃO E IMPASSES DE UMA NARRATIVA: \\ UMA LEITURA DE A HORA DOS RUMINANTES, DE JOSÉ J. VEIGA}

Dissertação apresentada ao Programa de Pós-Graduação do Departamento de Teoria Literária e Literatura Comparada, da Faculdade de Filosofia, Letras e Ciências Humanas da Universidade de São Paulo, para obtenção do título de Mestre.

Orientador: Prof. Dr. Ariovaldo José Vidal.

SÃO PAULO 
Aqui tudo parece que é ainda construção

e já é ruína.

Fora da ordem, Caetano Veloso. 
Em memória de meus pais. 


\section{AGRADECIMENTOS}

Ao professor Ariovaldo José Vidal, pela orientação precisa.

Ao professores da Faculdade de Letras da Universidade de São Paulo, mestres incentivadores.

À Solange Figueiras, por seu amor e compreensão.

Às minhas irmãs, irmão e sobrinho, pela torcida.

À Angelina da Silva Figueiras, in memorian.

À Luzia dos Santos Silva, pelo amor maternal.

À Vilani de Pádua, pela revisão e sugestões.

À Biblioteca do SESC de Goiânia, pela prontidão e gentileza no atendimento.

Ao Luiz Mattos, pela ajuda prestativa.

A todos colaboradores e incentivadores impossíveis de serem aqui nomeados, mas que de alguma maneira foram importantes para a realização deste trabalho. 


\section{RESUMO}

Este trabalho tem como finalidade a análise e interpretação da narrativa $A$ hora dos ruminantes, de José J. Veiga. O objetivo é identificar no enredo a representação de indícios da chegada de um novo momento histórico no Centro-Oeste brasileiro em meados do século passado, ao mesmo tempo em que se procura atentar para certa inovação formal na configuração dessa matéria local em processo de mudança. Essa inovação se dá pela intromissão de um elemento insólito numa narrativa cujo percurso é de característica realista. O elemento insólito é aqui interpretado não como um recurso ao fantástico e sim como um recurso alegórico, com apoio na concepção benjaminiana de alegoria. Antes da análise da obra é feita uma sucinta retrospectiva de algumas narrativas do autor nas quais se procura indicar precedentes que justifiquem o argumento. Essa retrospectiva é útil também para uma melhor contextualização de $A$ hora dos ruminantes na evolução técnica do escritor.

Palavras-chave: José J. Veiga; A hora dos ruminantes; realismo; insólito. 


\begin{abstract}
This work is focused on a careful examination and interpretation of the narrative written by José J. Veiga - A hora dos ruminantes. The real aim of this essay is to identify in the plot some traces of the new historical moment coming in the Brazilian West-Center in mid past century. Meanwhile, a certain formal innovation in the arrangement of this local subject is in a changing process. The introduction of this new idea is caused by an unusual interference of an element in the narrative, which path takes into account some realistic features. Here the unusual element is seen not as an ability in dealing with the strange and unreal, but as an allegorical resource based in the benjaminian general conception of the allegory. A brief retrospective analysis is useful to understand a better contextualization of Veiga's work - A hora dos ruminantes - in the whole author's technical evolution.
\end{abstract}

Key words: José J. Veiga; A hora dos ruminantes; realism; unreal. 
SUMÁRIO

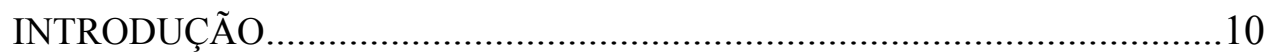

1. BIOGRAFIA COMENTADA

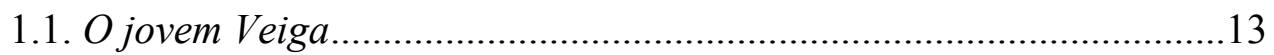

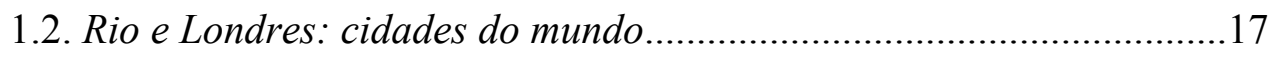

1.3. Jornalismo e Literatura ........................................................................21

2. TEMAS E FORMAS: PRECEDENTES

2.1. O tema infância e narrativas curtas......................................................29

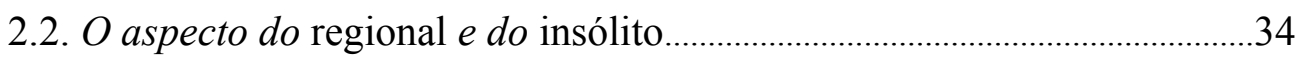

2.3. A usina atrás do morro $e \mathrm{O}$ galo impertinente.....................................42

3. ADEQUAÇÃO E IMPASSES DE UMA NARRATIVA

3.1. Reificação e subserviência: as fissuras do solo....................................52

3.2. Cooptação e resistência: do provável ao possível.................................78

3.3. Perdas e ruínas: a reconfiguração do mundo.......................................110

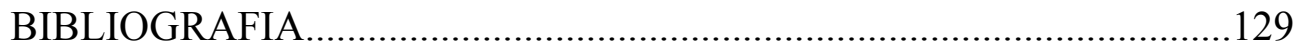




\section{INTRODUÇÃO}

José J. Veiga surgiu com relativo destaque na cena literária brasileira na segunda metade da década de 1960, com o lançamento de seus três primeiros livros. Na década seguinte o escritor optou por seguir as trilhas do romance e paralelamente viu suas narrativas curtas se sedimentarem no gosto do público através de inúmeras reedições. Entre os anos de 74 e 75 foram oito reedições quatro delas somente de Os cavalinhos de Platiplanto. Os anos 80 foram de muita produção do escritor - foi a década de sua aposentadoria da editora da FGV - com traduções e incursões na literatura infantil e na composição de um Almanaque. Na década de 90, mais traduções e o lançamento de seus três derradeiros livros, o último deles, curiosamente, um livro de contos, num simbólico retorno às narrativas curtas.

Em vida o escritor sempre foi discreto e pouco afeito a grandes badalações literárias apesar do fácil trâmite entre os meios jornalísticos e intelectuais. Após seu falecimento, a obra do escritor parece ter sido deixada um pouco de lado sob os rótulos, interessantes para o mercado editorial, de fantástico e literatura infantil. A presente dissertação pretende ser, portanto, uma modesta contribuição na tentativa de manter em aberto o debate sobre a obra de José J. Veiga, escritor de reconhecido talento dentro da boa linha média da literatura brasileira.

O trabalho está dividido em três partes. A primeira delas é uma pequena biografia comentada que visa justamente destacar algumas informações importantes para se entender a formação do homem, do intelectual e do escritor. Julgou-se necessária a biografia porque as informações nela resumidas são encontradas apenas esparsamente, recolhidas em livros, periódicos, revistas, teses, orelhas de livro, etc. Obviamente não se trata de uma biografia minuciosa, pois, como foi dito, a intenção é 
apenas destacar informações que possam ser relevantes para um maior entendimento da obra do escritor e desta leitura proposta.

A segunda parte da dissertação procura identificar nos contos do escritor alguns procedimentos que estarão presentes em $A$ hora dos ruminantes, objeto central deste trabalho. Ao abordar algumas dessas narrativas a intenção é expor certos conceitos e pontos de vista que possam permitir um entendimento mais objetivo das idéias que orientam a leitura.

Essa segunda parte é subdividida em três tópicos. O primeiro deles aborda o tema infância e a forte relação que possuem as narrativas dos três primeiros livros do escritor. A idéia aqui é destacar sucintamente esses livros como um núcleo de obras bastante peculiar na comparação com os demais títulos de Veiga, cuja opção pelo romance nas obras seguintes já parece indicar certa procedência da idéia.

O segundo tópico aborda mais dois temas importantes para a leitura de $A$ hora dos ruminantes, o regional e o insólito. Com relação a este último o que se pretende tão somente sugerir é que ele, o insólito, era apenas uma das várias formas de representação utilizadas por Veiga, fato que por si mesmo já parece indicar a inadequação da classificação de fantástica, genericamente, à obra do escritor.

O terceiro tópico concentra a atenção em duas narrativas cujos sentidos ecoam no livro a ser analisado. O primeiro conto é $A$ usina atrás do morro, basicamente a matriz de $A$ hora dos ruminantes. O que interessa ressaltar, então, é a presença de longa data do tema como uma necessidade e um desafio circulando em volta do processo criativo do escritor. Se esse conto é interessante por anteceder, no nível do significado, a fatura de $A$ hora dos ruminantes, $O$ galo impertinente também o é por efetuar essa antecedência no nível da natureza da imagem construída. Assim, procura-se demonstrar 
que alguns contos podem servir como pistas para um entendimento mais abrangente da leitura do nosso objeto de estudo.

A terceira parte é a análise e interpretação propriamente dita de $A$ hora dos ruminantes. Também ela é subdividida em três tópicos, cada um deles se ocupando de um capítulo do livro. Essa estrutura acaba facilitando uma leitura que segue os passos da voz narrativa e há aí, salvo engano, um aspecto positivo e outro negativo. O negativo é a maior probabilidade de se deixar levar pelas armadilhas do narrador, o que fatalmente deve ter ocorrido num momento ou noutro desse percurso. $\mathrm{O}$ aspecto positivo consiste na possibilidade de se perceber de maneira mais direta a configuração fragmentada das coisas do mundo a partir do olhar do narrador. Julgou-se que o risco valia a pena.

O primeiro tópico enfoca, então, a chegada dos forasteiros e o movimento de cooptação que se opera sobre dois personagens mediante um processo de esvaziamento da personalidade através do trabalho e um processo de subserviência voluntária e interesseira. O segundo tópico enfoca a ocupação da cidade pelos cachorros e a reação dos manarairenses, além das relações estabelecidas pelos estranhos com mais dois personagens, uma relação de cooptação que se dá através da lógica do favor e um movimento de resistência que surge em meio à apatia geral. O terceiro tópico, por fim, centra-se na questão da imagem final do livro, a da invasão dos ruminantes e a imagem de morte que a acompanha. Ciente das características realistas do livro, a sugestão apresentada é a leitura dessa figura como um recurso alegórico, o que leva a algumas considerações necessárias e, espera-se, minimamente interessantes. 


\section{BIOGRAFIA COMENTADA ${ }^{1}$}

\subsection{O jovem Veiga}

José J. Veiga nasceu a dois de fevereiro de 1915, no Estado de Goiás, numa fazenda entre os municípios de Pirenópolis e Corumbá, cidades de origem, respectivamente, de seu pai e sua mãe, Luiz Pereira da Veiga e Maria Marciana Jacinto Veiga. O casal, vivendo nessa última cidade, teve cinco filhos, dos quais José foi o segundo. O pai era pedreiro e a mãe dona-de-casa, responsável pelo aprendizado de leitura dos filhos mais velhos, José e Juvenal, que na escola terão um contato inicial com a literatura através da coleção $O$ tesouro do menino e, especialmente, da obra de Júlio Verne. A infância do garoto, até os dez anos, foi como tantas outras do lugar, à beira dos rios, visita às chácaras de parentes e à fazenda do avô materno, sempre entre as duas cidades que serão algumas das referências mais fortes na literatura do escritor.

O primeiro automóvel circula no Estado de Goiás em 1918 e o primeiro colégio de padres aparece na cidade de Bonfim apenas na década de vinte, assim como também as primeiras usinas hidrelétricas e as estações de trem da estrada de ferro (1922). Para se ter uma idéia aproximada da baixa densidade demográfica desses lugares no início do século vinte, basta dizer que o censo populacional da cidade de Corumbá, já em 1940, indicará um número de, aproximadamente, mil habitantes.

José e os irmãos sofrem um duro golpe quando, em 1925, tornam-se órfãos de mãe. Alguns tios, pequenos fazendeiros, adotam os meninos separando-os, dada a

\footnotetext{
${ }^{1}$ Para a composição dessa biografia foram utilizadas basicamente três obras; são elas:

CAMPEDELli, Samira Y. José J. Veiga. Biografia por Moacir Amâncio, São Paulo, Abril, 1982

PRADO, Antonio Arnoni. Atrás do mágico relance: uma conversa com José J. Veiga. Campinas, Editora da Unicamp, 1989;

SOUZA, Agostinho Potenciano de. Um olhar crítico sobre o nosso tempo: uma leitura da obra de José J. Veiga. Campinas, Editora da Unicamp, 1990.
} 
dificuldade de uma adoção de todas as crianças pela mesma família. O garoto deixa, então, a pequena cidade em que morava e vai para um sítio. Lá, segundo depoimento, encontra alguns poucos livros de poesia, que junto com os almanaques de fim de ano, distribuídos pelos laboratórios, e algumas revistas emprestadas, eram as poucas leituras disponíveis.

Na obra do escritor José J. Veiga o tema da perda da mãe será tratado em pelo menos três contos, dos quais $A$ viagem de dez léguas é o mais eloqüente sobre esse aspecto biográfico pouco abordado pelo autor em suas entrevistas. Podemos dizer ainda que este fato se faz presente em sua literatura mesmo pela ausência de figuras maternas, ou mesmo, de maneira mais geral, pela ausência de figuras femininas em muitas de suas histórias.

Passados dois anos no ambiente campestre do sítio, após uma visita em que os tios da capital descobrem a inclinação do pequeno José para a leitura, o menino é levado para a casa destes parentes, a família Costa Campos, moradores de uma chácara na cidade de Goiás Velho, então capital do Estado.

Nessa cidade, José faz o liceu, estuda francês e inglês e freqüenta os dois centros de leitura de que dispunha o município, o Gabinete Goiano de Leitura (Biblioteca Pública) e a Biblioteca do Convento dos Frades Dominicanos. Segundo as próprias palavras do escritor, foram anos de leitura intensa, dos clássicos brasileiros e portugueses, passando pelos românticos e realistas franceses, até a coleção de livros para moças Madame Delly. Um colega de classe, escocês, ajuda-o no aprendizado da língua inglesa e José consegue boas notas na disciplina.

Em 1933 o jovem Veiga termina o liceu e, acabados os estudos, o objetivo passa a ser o de arranjar um trabalho, objetivo difícil num lugar pequeno e de escassas oportunidades. Consegue um emprego no comércio, como caixeiro das Lojas 
Pernambucanas e o trabalho ganha mais importância pela ocorrência do falecimento do patriarca da família Costa Campos: à falta do tio, é necessária a ajuda de todos para a manutenção da casa.

Durante a década de trinta será iniciado o processo de modernização do CentroOeste brasileiro, processo que se estendeu pelas décadas de 1940 e 1950, com a expansão da linha férrea até Anápolis, interligando o Centro-Oeste ao Sudeste, fato que permitiu o crescimento populacional ao sul do Estado de Goiás que recebia migrantes mineiros, paulistas e nordestinos. Além da expansão da estrada de ferro, outros acontecimentos marcam, na década de 30, o processo de desenvolvimento do Estado, como a mudança de capital para a cidade de Goiânia, que ocorrerá somente em 1937, mas cuja pedra fundamental fora lançada em 1933, ano da maioridade de Veiga.

Ainda como parte de todo este processo, o governo federal irá também criar a Colônia Agrícola Nacional de Goiás, em 1941, com a intenção de expandir a produção de alimentos na região; além disso, por determinação da constituição de 1946, o planalto central será escolhido para sede da nova capital do Brasil, concretizada com a construção e inauguração de Brasília. Esses são alguns dos condicionamentos relevantes do processo de modernização do Estado de Goiás que tiveram como testemunha, pelo menos no seu início, o jovem José Veiga.

Como decorrência natural de seu trabalho no comércio, o rapaz amplia seu círculo de amizades e conhece algumas pessoas que serão importantes para o seu futuro próximo, entre os quais, Glauco Baiocchi, Mário Natal e Silva e certo Oscar Breitbarst, homem culto, judeu polonês que vendia refrescos para os jovens no centro da cidade de

Goiás Velho. É este experiente amigo que aconselhará José Veiga a procurar um futuro mais promissor numa cidade maior. Oscar Breitbarst era formado em Agricultura na Polônia e sonhava comprar alguma terra para desenvolver culturas agrícolas diferentes 
em Goiás. Além do conselho, Veiga ganhou de seu fraterno amigo 400 mil réis como uma ajuda para a passagem e para os primeiros momentos, sempre difíceis, da vida numa nova e grande cidade. 


\subsection{Rio e Londres: cidades do mundo}

O ano era 1935 e o destino escolhido foi a cidade do Rio de Janeiro, então capital do país, para a qual já haviam ido os amigos Mário e Glauco, este na intenção de prestar Exame para a Escola Militar. Veiga hospeda-se na casa do irmão de Glauco, na famosa Lapa dos anos 30, e imita o amigo na preparação para os exames, valendo-se das apostilas do curso preparatório que este freqüentava. O Ministério da Guerra, no entanto, comunicou aos inscritos para a Escola Militar que não haveria exame naquele ano devido à insuficiência de vagas. Glauco retorna a Goiás e o jovem Veiga permanece na capital tentando arranjar trabalho, tarefa na qual é auxiliado pelo outro amigo, Mário, que o encaminha a um emprego no Laboratório Científico São Jorge, para ser propagandista de produtos.

O emprego era cansativo e algum tempo depois, enquanto comia um sanduíche num bar do subúrbio, ouviu o anúncio da rádio Guanabara requisitando pessoas para testes com vistas a preencher cargos de locutores. Veiga decidiu tentar o emprego e marcou uma prova, conseguindo um bom desempenho e uma vaga como locutor da emissora. Ao final da década de trinta, porém, a concorrência entre as rádios se intensificava e o surgimento de emissoras mais ricas e modernas fez com que a Guanabara, em poucos anos, entrasse em decadência, inclusive com costumeiros atrasos de pagamentos.

Em 1939 dois acontecimentos marcam a vida do jovem goiano: primeiro, inscreve-se num concurso público para escriturário, conseguindo a vaga que lhe dará alguma tranqüilidade profissional; depois, a Faculdade de Direito abre o curso noturno e, após mais um bom desempenho nas avaliações, Veiga consegue sua matrícula. Como 
jovem aplicado que demonstrara ser até então, conclui seus estudos em cinco anos e a formatura ocorre em 1943, embora não conste que ele tenha exercido, depois dessa data, qualquer trabalho ligado ao Direito.

Veiga, no entanto, suporta a vida burocrática na repartição até 1945, ano de um acontecimento de imensa importância para suas futuras atividades de escritor e jornalista: novamente uma rádio anunciava concurso para um cargo de locutor e a rádio em questão era tão somente a BBC de Londres. Mais confiante pela experiência anterior, além das experiências positivas em concursos diversos, o futuro escritor consegue um bom desempenho e é contratado para trabalhar na capital inglesa.

Em fevereiro de 1945, com trinta anos recém completados, inicia uma permanência riquíssima na Inglaterra: até 1949, Veiga trabalhará na rádio britânica como comentarista e tradutor de programas para o Brasil, além de freqüentar a vida cultural da cidade: produção jornalística, crítica cinematográfica, leituras constantes, tradução de escritores franceses para a UNESCO, exposições, peças teatrais. Faz várias amizades, principalmente com brasileiros residentes ou em atividades profissionais na capital inglesa, como por exemplo, Antônio Callado, e também não deixa de acompanhar o que ocorre de novo nas letras nacionais, como o lançamento de Sagarana, de João Guimarães Rosa, em 1946, que Veiga leu no mesmo ano.

Segundo depoimento, foi neste período em Londres que entrou em contato pela primeira vez com a literatura de Franz Kafka, através do livro $O$ processo, num momento em que o escritor tcheco já constava como leitura obrigatória no meio intelectual europeu. A notação é importante na medida em que é este o único autor que realmente será assumido como influência na produção literária do futuro escritor, embora nomes como os de Aldous Huxley, George Orwell e Ray Bradbury sempre figurem, não precisamente como influências, mas como autores que serviram como 
sugestão para a construção de um ambiente de futuro em ruínas cujas ressonâncias serão, mais tarde, constatáveis na literatura do autor de $A$ máquina extraviada.

Encerrado o contrato de trabalho com a BBC, as opções eram a naturalização inglesa ou o retorno ao Brasil. Segundo o autor, o fato de que "não havia mais ditadura" no país (a ditadura de Vargas) foi um dado importante para sua decisão de voltar a solo brasileiro. Já no Rio de Janeiro tratou de restabelecer contatos, rever amigos e procurar trabalho.

Num primeiro momento pôde recusar ofertas profissionais não muito satisfatórias, por ter conseguido um pequeno prêmio de loteria, até aceitar, então, o cargo de redator no jornal $O$ Globo, empresa na qual trabalhará pouco tempo, já que a então recém-fundada Tribuna da Imprensa o convidará para ser seu redator-chefe.

Veiga permanece nessa instituição por mais de um ano até ser convidado pelo amigo Antônio Callado para substituí-lo como redator-chefe das Seleções do Reader's Digest. O cargo exigia um exercício diário com a escrita através do material vindo dos Estados Unidos, livros e artigos muitas vezes já condensados, que eram traduzidos e adaptados por Veiga.

Serão nesses anos iniciais do seu retorno ao Brasil $(1951,1952)$ que o jornalista José Veiga começa a percorrer os caminhos da literatura. A primeira leva de sua produção chegou mesmo a ensaiar uma possível publicação quando em, mais ou menos, 1953, Veiga apresentou, para ser avaliada, uma coletânea de contos no Ministério da Educação, que publicava, à época, os Cadernos de Cultura, nos quais havia espaço reservado aos contos. No dia seguinte, arrependido da ousadia ("Eram contos regionais, não tinham maior conteúdo") o escritor recolhe os originais alegando uma necessária correção e joga-os fora. Em toda essa experiência algumas características do autor já 
parecem se destacar, como a manifesta predileção por narrativas curtas e a opção em não querer ser apenas um epígono do regionalismo.

Desta maneira Veiga recolheu-se por mais cinco anos, tempo em que abandonou as noites de tranqüilos passeios com a mulher ou os encontros para uma cerveja com os amigos, pela constante lida com a literatura, sempre à noite, em terceiro expediente, após a jornada diária de trabalho.

É nesse período também, porém num contexto totalmente extra literário, que Veiga conhece Guimarães Rosa, através de um contato que se deve inicialmente às preocupações que as esposas de ambos possuíam sobre gatos. Desse prosaico contato nasce um relacionamento amigável que se estendeu por periódicas visitas regadas a leituras de trechos literários (sempre produção de Guimarães Rosa, segundo Veiga). O grau dessa amizade, por parte do escritor mineiro, pode ser constatado através das dedicatórias de seus livros a José J. Veiga: na de Corpo de Baile o autor indica que Veiga e D. Clérida foram os primeiros leitores daquelas novelas, enquanto que na de Primeiras Estórias o genial escritor assina simplesmente como Joãozinho. 


\subsection{Jornalismo e Literatura}

Foi assim que, em 1958, nesse ambiente de trabalho na redação, atividade literária em casa e poucas, mas valiosas relações sociais, que o jornalista inscreveu-se para concorrer ao prêmio Monteiro Lobato, promovido pela Editora Nacional e pela Academia Brasileiras de Escritores, seção São Paulo. O primeiro lugar foi para Vento de mar aberto, de Geraldo Santos, e o segundo para Os cavalinhos de Platiplanto, de José Veiga, que a partir de sugestão numerológica do amigo Guimarães Rosa, passará a ser chamado José J. Veiga.

Havia no regulamento do concurso uma previsão de que os primeiros colocados ganhariam o direito de publicação dos livros pela Editora Nacional, o que não ocorreu devido à crise do mercado editorial naquele momento. Apesar disso, em 1958 ocorre a primeira publicação de um conto do autor. Trata-se da narrativa O largo do Mestrevinte, publicada no Suplemento do Jornal do Brasil. O conto, curiosamente, não faz parte d'Os cavalinhos de Platiplanto; ele será incluído, daí a dez anos, no livro intitulado inicialmente $A$ máquina extraviada, de 1968. Esse fato, inclusive, reforça a idéia já explicitada pela crítica de que os primeiros livros de Veiga, especificamente os três primeiros, trazem uma marca muito peculiar que os distinguem do restante da obra do escritor.

Após receber de volta os originais, segundo o escritor, apareceu um senhor interessado em publicar o livro. No entanto, o novato editor possuía mais vontade que 
estrutura e com exceção de alguns exemplares distribuídos para poucas livrarias e para a imprensa, o resto da edição, a maior parte na verdade, não pôde ser retirado da gráfica por falta de pagamento. Essa edição também guardava um detalhe do qual só se ficou ciente depois de consulta ao espólio do escritor e o contato com um desses raríssimos exemplares: é que o desenho da capa dessa primeira edição é de autoria de D. Clérida Veiga, fato pouco comentado justamente pela falta de acesso dos estudiosos do escritor a essa primeira edição. Não deixa de ser curioso, portanto, o fato de que o livro acaba sendo a estréia do casal nos meios editoriais.

Apesar de todo o problema de distribuição e da falência da Editora Nítida, a obra ganha o prêmio Fábio Prado de 1959 e é elogiada pela crítica. Estes mesmos motivos serão, também, a raiz do mistério que envolverá o nome do escritor e do livro: falava-se sobre Os cavalinhos de Platiplanto, mas pouquíssimas pessoas haviam lido os contos.

O acolhimento positivo pela crítica especializada, além de ter dado uma óbvia satisfação pessoal, parece ter, ao mesmo tempo assustado o escritor, como várias vezes teve a oportunidade de sugerir em entrevistas. Era muito claro para ele que o elogio da crítica significava ao mesmo tempo uma maior cobrança, ou pelo menos, uma maior expectativa, sobre outras histórias que pudesse vir a publicar. Essa clara idéia de que seria cobrado para, no mínimo, manter o nível de sua produção literária parece que serviu como um freio e um bloqueio na sua euforia de escritor estreante.

Aos poucos o autor foi retornando ao seu ritmo normal, tanto na redação das Seleções quanto na sua produção literária, publicando esporadicamente alguns contos, sempre no Suplemento do Jornal do Brasil. Estas narrativas, e outras inéditas, terão o mesmo destino que aquele primeiro conto publicado no jornal, ou seja, farão parte de sua segunda coletânea de contos. 
Antes, porém, em 1961, como afirmam alguns dos principais estudiosos de Veiga, o escritor iniciou a redação do seu segundo livro, que teve, ao longo de quase três anos, pelo menos cinco versões. O livro ficou pronto em fins de 1963, mas só no ano seguinte foi apresentado à Civilização Brasileira pelas mãos de Carlos Heitor Cony. No entanto, "o ano seguinte" não foi dos mais calmos na história recente do Brasil. A deposição de João Goulart e o Golpe Militar deixam muitos setores da sociedade e muitos cidadãos ressabiados, embora num primeiro momento não tenha havido evidentes limitações de direitos ou perseguições políticas.

A editora, no entanto, prefere aguardar um pouco mais para evitar qualquer possibilidade de ressalvas, ou talvez mesmo porque acreditasse numa rápida solução para o estado de exceção do momento. Por um motivo ou outro o livro só foi lançado em 1966 e, enfim, um público maior passa a conhecer a obra de José J. Veiga. Talvez seja pertinente essa curiosa notação sobre a recepção da obra veigueana: o primeiro livro do escritor, como foi dito, sofreu muitos problemas editoriais e só terá uma segunda edição em 1970. Até esta data, no entanto, A hora dos ruminantes já estará em sua $2^{\mathrm{a}}$ edição, além da inclusão de um terceiro título na bibliografia do escritor.

É possível, portanto, perceber que $A$ hora dos ruminantes acaba sendo uma "segunda estréia" do autor, pelo menos do ponto de vista do público, agora, porém com toda uma expectativa dos meios literários em torno de seu nome. Apesar disso, o contexto em que o livro aparece - 1966, segundo para terceiro ano da ditadura militar é um contexto bastante distinto daquele em que a obra foi composta e apresentada à editora, todo este período de intensas transformações sociais, políticas e econômicas.

Mesmo assim não houve nenhum problema com veículos de censura ou qualquer outro tipo de restrição ao livro pelos órgãos do governo autoritário. Mas se a interpretação temida pela Civilização Brasileira não ocorrera com os órgãos de censura, 
ela ocorre sim por parte dos leitores que num primeiro momento parecem relacionar o estado de exceção que o Brasil vive, com a invasão de uma nova ordem narrada no livro (num momento em que esta característica talvez fosse julgada como positiva). De qualquer maneira o livro teve uma boa recepção entre público e crítica, sendo para alguns, a obra com que Veiga impõe-se como escritor significativo na literatura brasileira.

Após dois anos de A hora dos ruminantes, portanto em 1968, surge o terceiro livro do escritor, e segundo de contos, A máquina extraviada, publicada pela editora Prelo do Rio de Janeiro. A partir da $4^{\text {a }}$ edição, de 1981, pela Civilização Brasileira, o livro passará a se chamar $A$ estranha máquina extraviada. Embora contenha alguns contos primorosos, o livro não teve maior repercussão entre público e crítica, talvez pela falta de ineditismo de algumas narrativas.

Em 1970, tanto $A$ hora dos ruminantes quanto $A$ máquina extraviada ganham tradução inglesa de Pamela G. Bird para publicação nos Estados Unidos por Alfred A. Knopf, de Nova Iorque. O primeiro livro recebe o título de The three trials of Manirema, e o segundo, The misplaced machine and other stories. A crítica norteamericana interessada na produção literária da América Latina elogia os livros, mas isso não se traduz em boas vendas, talvez porque o público pensasse num tipo de exotismo tropical do qual o livro não é pródigo.

Ainda em 1970 ocorre algo que alterará a vida profissional de Veiga: a redação de Seleções transfere-se para Portugal e o escritor perde seu emprego. Aproveita a indenização que recebe e tira um ano de férias, ocasião em que aproveita para visitar o local que deixara há trinta e oito anos e para o qual não havia retornado desde então. Corumbá, Pirenópolis, Goiás Velho, o autor sente grande emoção de novamente estar nas cidadezinhas que sempre estiveram presentes nele e em suas narrativas. Essa visita, 
em 1971, parece ter tido um profundo efeito no escritor e a partir daí suas visitas à terra natal serão bem mais freqüentes.

Nesse mesmo ano, de volta ao Rio de Janeiro, Veiga começa a redação do seu primeiro romance, que, após três versões, é lançado pela Civilização Brasileira no ano seguinte, 1972. A obra, Sombras de reis barbudos, é premiada pelo Instituto Nacional do Livro, e a crítica aponta a presença de um Ciclo Sombrio na obra do autor, com narrativas que desde o primeiro livro denotam uma atmosfera cada vez mais tensa e opressiva. Também em 1972 sai pela Editorial Novaro S.A, do México, Los caballitos de Platiplanto, com tradução de Agustín Contin.

O ano de 1972 também é marcado pela volta do escritor às redações, desta vez a do Departamento de Documentação da Faculdade Getúlio Vargas, onde se torna um dos colaboradores da edição em português de O Correio da UNESCO. Os três anos posteriores a 1972 serão de constantes reedições dos livros de Veiga, com especial destaque aos anos de 1974 e 1975 em que são publicadas oito edições de suas obras, quatro dessas edições somente do primeiro livro e todas pela Civilização Brasileira.

Em 1976, o escritor publica o quinto livro, Os pecados da tribo, que recebeu o prêmio do Pen Clube do Brasil no mesmo ano. O livro, no entanto, não alcança o sucesso dos anteriores e tem modesta penetração entre os leitores. A opressão é ainda a nota dominante nas histórias, mas parece haver uma crise na própria possibilidade de representação dessa opressão, que anteriormente era só sugerida na ambigüidade dos estranhos e que agora chega à concretude do animalesco.

Em 1980 ocorre um retorno do escritor às narrativas mais curtas. O livro é De jogos e festas e compõe-se de duas novelas e um conto. A obra ganhou, no mesmo ano, o Jabuti da Câmara Brasileira do Livro, na categoria Contos, Crônicas e Novelas, e também o Prêmio Literário São Paulo, do Centro Cultural Francisco Matarazzo 
Sobrinho, pela melhor obra de ficção entre 1980-81. Este será também o último título inédito lançado pela Civilização Brasileira, e é, de certa maneira, uma tentativa do escritor de abandonar aquela temática opressiva do ciclo sombrio, embora reconheça posteriormente que não chega a ser algo muito distinto dos demais.

Diferente mesmo é outra obra lançada no mesmo ano, 1980. Trata-se da primeira criação infanto-juvenil do escritor, O professor Burrim e as quatro calamidades, título publicado pela Editora Comunicação de Belo Horizonte. A década de 80 será de muitos outros lançamentos de José J. Veiga, pois é esse o decênio em que, quantitativamente, o autor mais publicou. Em 1982, pela Difusão Editorial, a DIFEL, lança Aquele mundo de Vasabarros, título que finaliza o já famoso ciclo sombrio iniciado com o conto $A$ Usina atrás do morro, do primeiro livro. O livro ganha o prêmio Jabuti de 1983 na categoria Romance.

O escritor, aos setenta anos, chega à aposentadoria em 1985, no cargo de chefe da Editora da FGV e agora dispõe de mais tempo para sua produção literária. Torvelinho dia e noite, lançado no mesmo ano de 1985, já traz uma história isenta do clima opressivo dos anteriores e a literatura de Veiga vai se tornando mais permeável a um otimismo poucas vezes visto em seus enredos. Talvez essa característica seja reflexo do ambiente político da abertura, no início da década de oitenta, com o movimento das eleições diretas e as manifestações para democratização do país.

O fato é que na mesma linha de otimismo e de uma temática de convívio fraterno entre as pessoas, como em Torvelinho dia e noite, surge em 1986 o segundo livro infanto-juvenil de Veiga, Tajá e sua gente, publicado pela Editora Salamandra. Segundo Agostinho de Souza, "Nesses dois livros J. Veiga extravasa um sonho de convivência harmoniosa, positiva, que ficou retraído nos livros anteriores”. 
Em 1988, Veiga lança um livro no gênero dos antigos almanaques tão lidos pelo escritor em sua juventude. Na verdade, trata-se, segundo o escritor, da restauração de um almanaque que já existira com apenas o primeiro número lançado, em 1827. Portanto, o lançamento de Veiga, em 1988, propõe-se a ser o segundo número do antigo, verdadeiro e único Almanach de Piumhy, 161 anos após o lançamento do primeiro número. O livro é lançado pela editora Record que no ano seguinte, 1989, publicará o número três do Almanach, sempre com textos curtos bem-humorados e irônicos.

Ainda em 1989, agora com os direitos autorais definitivamente adquiridos pela editora Bertrand Brasil, o escritor lança o romance histórico A casca da serpente, que se propõe a fazer uma "retificação" do massacre, pelos militares republicanos, da população de Canudos e de seu líder Antonio Conselheiro. O livro é de certa forma surpreendente dado o perfil da literatura de Veiga até então, mas é compreensível a tentativa do escritor num momento em que o romance histórico parecia ganhar um novo fôlego através de diversas publicações.

Em 1991, a editora Marco Zero publica, com tradução de Veiga, uma obra de um escritor norte-americano que se tornou famoso nas décadas de 60 e 70. Trata-se do romance Pescar truta na América, de Richard Brautigan, que, quando publicado em 1967, vendeu quase dois milhões de exemplares. O escritor americano teve seu nome ligado à geração beat mais pelas relações pessoais que mantinha com alguns desses escritores do que propriamente pelo seu estilo literário, para alguns, um estilo surreal. Segundo Veiga, Brautigan "foi um inventor. Ele conseguiu escrever seus textos como se estivesse inventando a literatura".

Quatro anos depois, em 1993, virá a público o livro O risonho cavalo do príncipe, com o qual o escritor ganhará mais uma vez o prêmio Jabuti na categoria 
Romance, desta vez dividindo o prêmio com Rachel de Queiroz, João Silvério Trevisan, Moacyr Scliar e Silviano Santiago.

Em 1994 mais uma tradução. Desta vez dos Contos cortantes, de Breece DJ Pancake, pela editora Bertrand Brasil. O livro é obra única desse outro escritor norteamericano que morreu jovem e pouco conhecido (assim como Richard Brautigan, também cometeu suicídio).

O relógio Belisário, de 1995, é o penúltimo livro do escritor, livro de um entretenimento leve que narra algumas histórias entrecruzadas e que têm a participação de Sherlock Holmes e até mesmo do escritor Lima Barreto como personagens da história.

O último livro do escritor publicado em vida, Objetos turbulentos, de 1997, curiosamente é uma coletânea de contos, após quase trinta anos de seu último livro dedicado exclusivamente às narrativas curtas. Esse retorno acaba por demonstrar que a produção literária de Veiga realmente dá um salto de qualidade às vezes em que o escritor opta pelas formas breves de narração. É certo que os contos do último livro não têm o lirismo original das histórias de Os cavalinhos de Platiplanto nem a contundência serena dos enredos de $A$ estranha máquina extraviada, mas ainda assim, Objetos turbulentos mostra-se como o melhor livro de Veiga depois de Sombras de reis barbudos. Nesse mesmo ano de 1997, a Academia Brasileira de Letras contempla o escritor com o prêmio Machado de Assis pelo conjunto da obra.

Dois anos depois, na cidade do Rio de Janeiro, em 19 de setembro de 1999, aos 84 anos, o escritor faleceu vitimado por um câncer no pâncreas. 


\section{TEMAS E FORMAS: PRECEDENTES}

\subsection{O tema da infância e narrativas curtas}

O conto "O largo do Mestrevinte", publicado em 1958, no suplemento literário do Jornal do Brasil marca a estréia literária de José J. Veiga. No mesmo ano o escritor ganhou o prêmio Fábio Prado com o livro de contos Os cavalinhos de Platiplanto, mas provavelmente devido a alguma cláusula de ineditismo das obras no concurso, o conto não fez parte desse primeiro livro. Em forma de hipótese talvez seja possível a seguinte conjectura: mesmo que lhe fosse permitido o escritor hesitaria em inserir " $\mathrm{O}$ largo do Mestrevinte" em sua primeira coletânea de contos. Essa impressão se baseia nas características tanto da narrativa quanto do livro, pois o conto traz uma configuração da infância distinta daquela que ocorre na maioria das narrativas da coletânea: é que em "O largo do Mestrevinte" os personagens infantis adquirem contornos terríveis e ferozes, agindo em bando com suas bicicletas velozes e intenções violentas: 
Lembrei-me que os meninos daquela zona eram conhecidos pela ferocidade, não fazia muito tempo eles tinham enforcado um afiador de facas só porque ele não quis tocar Escravos de Jó com uma lâmina de esmeril; o homem ficou pendurado em um poste dias seguidos, os moradores da rua proibidos de tocar nele, até que numa noite de tempestade o corpo caiu e foi levado pela enxurrada. ${ }^{2}$

Assim se recorda o narrador-personagem ao perceber o perigo que corria. Essas crianças do conto, portanto, já parecem ter perdido algo da infância descobridora do mundo, ingênua e curiosa, que vibra de maneira intensa em quase todas as narrativas de Os cavalinhos de Platiplanto.

O livro possui uma unidade que decorre em grande parte da posição do foco narrativo nas estórias: em primeira pessoa, um jovem narrador - criança, adolescente ou mesmo o jovem adulto debruçado sobre determinado evento entre sua infância e a recente adolescência - vai conhecendo as faces do mundo através da dor, da falta de comunicação, da incompreensão e violência, às vezes como personagem principal, às vezes como testemunha ocular.

A maioria das narrativas tem como tema, portanto, a aquisição da experiência de vida e do estar no mundo por essas crianças e adolescentes, o conhecimento progressivo das relações humanas, as relações familiares e as dificuldades do diálogo, as relações sociais e as dificuldades do convívio. O escritor descreve carências e luminosidades de jovens e crianças de pequenas cidades e povoados dos interiores do Brasil, as rupturas dolorosas na experiência da morte ou da separação, o alargamento da visão do mundo, as descobertas e aspirações, tudo isso inserido num processo de mudança social que desponta aqui e ali de maneira sutil.

\footnotetext{
${ }^{2}$ VEIGA, José J. "O largo do Mestrevinte”. In A máquina extraviada. $3^{\mathrm{a}}$ ed., Rio de janeiro, Civilização Brasileira, 1976, p. 59. A partir da $4^{a}$ edição o livro passou a se intitular A estranha máquina extraviada, mas a alteração não afetou o título do conto da antologia, anteriormente homônimo. Da terceira para a quarta edição também não houve alteração na numeração das páginas.
} 
No entanto, nos primeiros vinte anos de sua produção literária, Veiga nunca produziu nenhum tipo de literatura exclusiva para crianças ou adolescentes. Aliás, muito pelo contrário: a densidade de suas narrativas que trazem à tona os problemas da convivência e comunicação humanas, os elementos insólitos beirando o grotesco, a profundidade das reflexões sobre a existência, são aspectos de sua literatura que de certa forma desautorizam-nos a pensá-la como uma literatura voltada ao público infantojuvenil.

A comparação de "O largo do Mestrevinte" com a coletânea de contos não é gratuita. A intenção é fazer perceber que, ao estrear na literatura, o escritor já possuía alguma produção que seria utilizada em seu posterior livro de contos, fato interessante por indicar com quase absoluta certeza que a composição de A hora dos ruminantes, objeto principal desse trabalho, se deu simultaneamente à feitura de parte das narrativas que constituirão $A$ máquina extraviada. Esse fato parece apontar de maneira concreta para algo já observado anteriormente pela crítica, ou seja, que os três primeiros livros de Veiga possuem peculiaridades que os diferenciam em relação às suas demais obras.

Mas essa ligação quase umbilical entre as peças narrativas não se encerra aí, pois desde cedo a crítica percebeu também o reaproveitamento explícito, em $A$ hora dos ruminantes, de um conto do livro de estréia, o conto "A Usina atrás do morro". Além disso, o tema das duas estórias, a invasão de um lugar por um elemento estranho/estrangeiro, será retomado, de maneira significativa e exemplar, no livro $A$ máquina extraviada, com o conto-título e com o importante "O galo impertinente".

Para coroar essa forte afinidade entre as três primeiras obras de Veiga pode-se ressaltar a opção do escritor pelas formas curtas de narrar. Isso é evidente nos livros de contos, nos quais a opção pelo gênero se dá sem grande alarde formal, mas mesmo em A hora dos ruminantes é possível sentir fortemente essa tendência, na medida em que os 
capítulos do livro parecem estar estruturados em pontos centrais em volta dos quais se desenvolvem as ações da trama, inclusive, nomeando-os. Essa estrutura acaba dando certa impressão de autonomia dos capítulos e talvez não fosse descabido dizer que é possível mesmo fazer uma leitura, por exemplo, da primeira parte da estória como uma narrativa independente, cujo significado acabaria não sendo muito distinto do significado que possui na sua leitura linear dentro da estória.

A impressão que se tem, então, é que essa forma utilizada por Veiga se aproxima bastante da definição lukácsiana de novela utilizada por Carlos Nelson Coutinho em seu estudo sobre literatura e sociedade no século XX:

"Goethe distingue a novela do simples conto ao defini-la como 'a ocorrência de um evento inesperado'. (...) [Ludwig] Tieck desenvolve ulteriormente a definição goethiana: 'A novela deve ter um momento culminante, um ponto focal no qual um momento determinado é posto sob uma luz mais clara e mais forte'. (...) a novela deveria assim compendiar a vida em sociedade através de um evento singular extraordinário, tomado como ponto focal. (...) Nasce uma situação novelística sintomática quando a exasperação do caso singular, acima da média, faz aparecerem sob forma concretamente concentrada e clara os dados ético-sociais típicos de todo um conjunto de problemas. A novela não é obrigada a representar todo o conjunto de dados da vida social, como faz o romance." ${ }^{3}$

A adequação da narrativa a esse conceito de novela não altera profundamente qualquer leitura que se faça da estória, mas é interessante para se perceber a gradativa apropriação de formas efetuada pelo escritor para tratar de temas já presentes em sua obra nuclear que são seus contos. Isso porque no livro posterior ao $A$ máquina extraviada, o escritor retomará novamente o tema da invasão que já fora abordado em "A Usina atrás do morro" e $A$ hora dos ruminantes, no entanto agora em forma

${ }^{3}$ LUKÁCS, Georg apud COUTINHO, Carlos Nelson Lukács, Proust e Kafka: literatura e sociedade no século XX. Rio de Janeiro, Civilização Brasileira, 2005, p. 153. 
inequívoca de romance: Sombras de reis barbudos. A partir de então o escritor dará preferência absoluta a esse gênero, pois dos nove livros posteriores ${ }^{4}$, sete serão romances.

Há dois fatos na vida pessoal do escritor que parecem se refletir nessa sua opção de se dedicar a um gênero literário que até então não havia percorrido. $\mathrm{O}$ primeiro desses fatos é seu desligamento das Seleções do Reader's Digest, devido à mudança da redação da empresa para Portugal. O escritor ganhou uma indenização que lhe permitiu um período de descanso, do qual se aproveitou para rever sua cidade natal, e este é o segundo fato importante na vida e na carreira literária de Veiga. Após trinta e cinco de ausência o escritor revê a paisagem que tantas vezes evocou imaginariamente. De retorno ao Rio, Veiga se dedicará ao romance que será intitulado Sombras de reis barbudos e não é difícil perceber uma mudança sensível na configuração das cidades nas suas estórias a partir de então.

${ }^{4}$ Dessa conta excetuam-se $O$ almanach de Piumhy e os infantis Tajá e sua gente e Professor Burrim e as quatro calamidades. 


\subsection{O aspecto do regional $e$ do insólito}

Outro dado observado pela crítica sobre os primeiros livros diz respeito ao sabor regionalista das narrativas, com seus rasgos de cenas rurais, o falar espontâneo dos personagens com características típicas da vida no campo, a oralidade sem artificialismos e a relação direta do homem com o meio natural, tudo construído mediante uma forte noção estética que cria um clima de "nostalgia de um mundo perdido - na história do indivíduo e na história da comunidade." 5, como diz Tieko Miyazaki.

No entanto, há que se ressaltar o caráter desse aspecto regional, pois a literatura de Veiga não é dada a grandes descrições de ambiente, centrando sua atenção muito mais nas ações e nos acontecimentos da trama. O cenário surge, então, na maioria das

\footnotetext{
${ }^{5}$ MIYAZAKI, Tieko Y. Lendo José J. Veiga. São Paulo, Atual, 1988, p.118.
} 
vezes, a partir das ocorrências do enredo e de atitudes dos personagens. Ou seja, o cenário e a própria descrição física dos atores só ocorrem na medida em que são chamados a "atuar" na trama, no momento em que veiculam um significado objetivo e imediato para a trama. Esse traço do aspecto regional em Veiga é argutamente observado por José Aderaldo Castello:

Para as diferentes abordagens da realidade que nos transmite, o autor não se deixa preocupar com as especificidades da paisagem, de maneira a identificá-la "regionalmente". Na verdade, o que se impõe na concepção da paisagem é a configuração do espaço que comporte o clima de envolvimento de situações, conjunturas ou episódios singulares ou da condição humana. A paisagem, portanto, é ambientação concebida reciprocamente com a ação. Reduz-se ao essencial necessário ao dimensionamento do universo representado, em que freqüentemente se passa do equacionamento com o real para as libertações oníricas ou fantásticas. Contudo, quase todos os contos se apresentam equacionados com o universo rural em que se destacam pequenas propriedades e excepcionalmente pequenos vilarejos, reais ou imaginários. Sente-se sempre a presença desse universo sertanejo, interiorano, com seus valores e sua rotina de vida. ${ }^{6}$ (itálico meu)

É este senso formal aguçado que permite o tratamento dessa matéria, já presente em nossa tradição literária, através de um elemento estético que, se não é de todo inovador, tem, pelo menos, pouco presença entre nossos escritores, o insólito, que acaba por impedir a simples reprodução, por parte do escritor, das representações regionalistas mais tradicionais ou mais clássicas.

É fato que a literatura produzida no Brasil nas últimas cinco décadas tem se dedicado, de maneira mais sistemática e numerosa, a tratar do convívio humano nos centros urbanos, como decorrência natural do desenvolvimento industrial mais acentuado no país a partir de meados dos anos 50 e o conseqüente crescimento

${ }^{6}$ CASTELLO, José Aderaldo. "Do real ao mundo do menino possível". In Os melhores contos de J. J. Veiga. $4^{\mathrm{a}}$ edição, São Paulo, Global, 2000, pp. 5-6. 
demográfico das cidades. Portanto, já naquele momento de estréia de Os Cavalinhos de Platiplanto, mais de vinte anos após os principais romances sociais de 30, a produção de uma literatura de características regionalistas, principalmente após o evento Guimarães Rosa, era sempre um grande risco a se correr; risco de uma representação que ficasse apenas no pitoresco e no estereótipo, com pouquíssima, ou nenhuma, validade estética.

Veiga, ciente desse perigo, chegou mesmo a desistir de publicar contos propriamente regionalistas em meados da década de 50, e embora as narrativas de seu primeiro livro possam dar a idéia de uma matéria local, específica e particularizada, ficou claro, para boa parte da crítica, que essas narrativas não poderiam ser chamadas simplesmente de literatura regionalista.

A informação dessa desistência de publicar contos regionalistas tradicionais é interessante para se perceber a sempre presente intenção do escritor em tratar de uma matéria que nos remete à sua experiência vivendo no interior do país, antes da mudança para a cidade grande, ao mesmo tempo em que sente certa necessidade de uma forma mais adequada que seja capaz de dar conta de maneira consistente do momento específico que o material a ser narrado requer.

Uma simples comparação entre Veiga e Bernardo Élis, por exemplo, que é um dos nomes que compõem segundo Antonio Candido, a boa linha média da literatura brasileira na década de 50, evidencia o fato. Aliás, dentre todos os escritores que estrearam em 40 ou 50 e que são citados no ensaio A nova narrativa, somente Bernardo Élis é estabelecido como um regionalista autêntico; os outros, e não são poucos os citados, "os outros circulam no universo dos valores urbanos, relativamente desligados de um interesse mais vivo pelo lugar, o momento, os costumes". ${ }^{7}$

\footnotetext{
${ }^{7}$ CANDIDO, Antonio. "A nova narrativa". In A educação pela noite e outros ensaios. São Paulo, Ática, 1987, p. 206.
} 
A citação à literatura de Bernardo Élis não é gratuita na medida em que tanto ele como José J. Veiga são oriundos da mesma região e da mesma época, mas com formações distintas. Curiosamente os dois escritores nasceram em 1915 e faleceram em datas próximas, Élis em 1997 e Veiga em 1999, além de terem vivido durante a infância na mesma cidade, distantes um do outro apenas alguns quilômetros.

No entanto, os pontos de contato parecem acabar por aí, pois as relações familiares, os percursos profissionais, as influências literárias e as opções estéticas distinguem profundamente os dois escritores; se Bernardo Élis está mais próximo da representação estética realista tradicional, José J. Veiga é filiado aos exploradores do insólito, enfrentando o trabalho da forma literária, segundo Alfredo Bosi, de maneira mais "neutra e opaca", encravando "situações de estranheza em um contexto familiar, que evoca discretamente costumes e cenas regionais". ${ }^{8}$

Na concisa definição de Bosi, estão dadas as duas características essenciais da produção de Veiga principalmente nas suas primeiras e mais importantes obras: (A) a criação de situações estranhas que desnorteiam e invalidam a experiência de vida de comunidades que ocupam (B) um ambiente intimamente conhecido, o qual nos remete a um tipo de vida específico do interior do país.

Assim, com os contos do primeiro livro, simultaneamente ao fato de que a matéria abordada é retirada de nossa tradição - o desejo de cantar as cores locais -, o tratamento que o escritor dá a essa matéria é um tratamento de certa maneira inovador na medida em que introduz um elemento até então ausente na representação literária do ambiente rural, o insólito, que parece decorrer não de um irracionalismo ou de uma fantasia abstrata, mas sim de problemas concretos específicos: a violência doméstica sobre as crianças, a experiência infantil com a morte (da mãe, do avô, do animal

\footnotetext{
${ }^{8}$ BOSI, Alfredo. "Situações e Formas do conto brasileiro contemporâneo". In O conto brasileiro contemporâneo. $3^{\mathrm{a}}$ ed., São Paulo, Cultrix, 1978, p.20.
} 
preferido), a exclusão do grupo social gerando o isolamento e a loucura, a incomunicabilidade entre as pessoas, o choque do contato entre um modo de vida antigo e um novo causando, ao primeiro, a sensação de estranheza e até mesmo de algo que surge como extraordinário ou fantástico.

Realmente, um dos traços mais marcantes na literatura de Veiga desde sua estréia é o uso de elementos insólitos, característica que o vinculou desde o início ao chamado realismo fantástico num momento de descoberta do público brasileiro desse tipo de literatura. Veiga também teve sua produção literária associada ao nome de Murilo Rubião, precursor da moderna literatura fantástica no Brasil, pois quando Veiga estreou em 1959, Rubião já havia publicado dois títulos importantes - O ex-mágico, em 1947, e A estrela vermelha, em 1953 -, embora só viesse a ser amplamente conhecido posteriormente.

Apesar dessa aproximação entre Veiga e Murilo, o leitor percebe sem muita dificuldade que há diferenças importantes entre os dois escritores, sendo a primeira delas a que diz respeito à ambientação urbana das histórias do escritor mineiro em contraste com os espaços rurais dos enredos veiguianos. Além disso, o elemento fantástico na obra de Murilo parece se instaurar sem que isso cause maior espanto aos personagens envolvidos na trama, todos eles encarando uma situação transfigurada, assimilada à normalidade. Esse aspecto do fantástico em Murilo é sempre ressaltado por Davi Arrigucci Jr. nos textos que abordam a obra do escritor. Arrigucci afirma:

Desde sua estréia literária, Murilo Rubião pode ser visto como o criador de um mundo à parte. Sua marca de fábrica sempre foi o insólito. Para maior desconcerto nosso, um insólito que se incorpora, sem surpresa, à banalidade da rotina. $\mathrm{O}$ mundo à parte é também o nosso mundo. (...) Desde o princípio, o que mais espanta em Murilo é a perfeita naturalidade da 
convivência como espantoso. Apenas um detalhe fantástico se intromete, mas o mundo inteiro vira fantástico, sem perder os sestros de sempre. ${ }^{9}$

Em Veiga, ao contrário, o elemento insólito, ou mesmo propriamente fantástico, surge como algo que traz e imprime um estranhamento insidioso nas relações humanas e na relação do homem com a natureza, causando um espanto que não é somente o do leitor, é também compartilhado pelos personagens da trama; portanto, o acontecimento insólito nas estórias de Veiga é tido como insólito tanto pelos personagens como para o leitor. Mas mesmo aqui, como se verá, a natureza desse insólito é bastante peculiar.

Uma terceira distinção entre os dois diz respeito menos a uma característica inerente desse estranhamento do que a um fator externo de seu uso. É que o elemento fantástico é algo constante na literatura de Murilo, não havendo produção sua isenta dessa característica ${ }^{10}$, enquanto que em Veiga esse elemento é apenas um entre outros experimentos formais possíveis, ocorrendo, inclusive, menos vezes do que se imagina. Como diz Fábio Lucas:

Em J. J. Veiga (...) interferem traços realistas mais abundantemente do que em Murilo Rubião (...) Veiga escapa à ficção meramente fantástica ou à de inspiração mitológica. ${ }^{11}$

O que predomina na maioria das narrativas é uma recorrência ao insólito através do onírico, portanto, um procedimento narrativo até certo ponto tradicional no recurso à fantasia. Esse procedimento não exclui, necessariamente, o real representado, pois este segue paralelamente à fantasia, configurado como os limites concretos que a produziram. José Aderaldo Castello também destaca essa característica, acrescentando que ela é propícia à escolha dos temas e ambientes das primeiras narrativas do escritor:

${ }^{9}$ ARRIGUCCI JR., Davi. "Minas, assombros e anedotas (Os contos fantásticos de Murilo Rubião)". In Enigma e comentário, ensaios sobre literatura e experiência. São Paulo, Companhia das Letras, 1987, p. 141.

${ }^{10}$ Cf.: CANDIDO, Antonio. Op. cit., p. 208.

${ }^{11}$ LUCAS, Fábio. Razão e emoção literária. São Paulo, Duas Cidades, 1982, p. 43. 
(...) sem dúvida a riqueza maior do narrador reside exatamente na representação do universo da criança/adolescente naquele condicionamento rural. Oscila entre a relação com o universo adulto e a fantasia - devaneio ou mesmo sonho - peculiares da primeira idade. Talvez porque o espaço condicionador seja o rural, ele é propício aos sentimentos despojados, ingênuos ou puros. E com as possibilidades perceptivas e intuitivas da própria criança, além do seu poder de imaginação ou fantasia, se reconhece o universo circundante, seja do homem adulto, seja mesmo dos irracionais. ${ }^{12}$

Por outro lado, entre os contos dos dois livros de Veiga há um número razoável deles isentos de qualquer viés fantástico ou insólito, calcados num realismo sóbrio e num tratamento mais tradicional à matéria. Três desses contos, "Roupa no coradouro", "Entre irmãos" e "A viagem de dez léguas", abordam direta ou tangencialmente a morte da mãe como uma experiência infantil, inclusive podendo ser lidos de maneira complementar, e nessas narrativas é possível perceber ecos da vida pessoal do escritor mediante intenso trabalho de elaboração

Aqui, porém, cabe uma notação. Geralmente, as personagens femininas não possuem muito destaque nas narrativas de Veiga e mesmo nesses contos que envolvem a figura materna ela é referida sem a tonalidade afetiva costumeira do foco narrativo ao abordar as outras experiências infantis. Essa tonalidade até existe em "A viagem de dez léguas", mas referida muito mais ao problema da desagregação do núcleo familiar causada pela morte da mãe do que propriamente configurando a personagem materna, sintomaticamente ausente da trama. Essa ausência também se verifica no conto "Entre irmãos", em que o leitor é insciente do motivo de encontro dos irmãos até as últimas linhas da estória, quando, então, revela-se a causa. Todo propriamente dito se desenrola em volta dos sentimentos e das impressões do personagem-narrador ao conhecer, e nele reconhecer-se, um irmão que até então nunca vira.

\footnotetext{
${ }^{12}$ CASTELlO, J. A. Op. cit., p. 7.
} 
Dos três contos somente "Roupa no coradouro" possui uma configuração empírica da mãe, mas ainda aqui o que mais se destaca é a incapacidade da criança de compreensão da situação que a envolve, tornando-se ela mesma causadora indireta do agravamento do estado enfermo da mãe, do qual somente aos poucos vai se dando conta, com uma suave carga de dramaticidade se inserindo na estória. A figura da mulher nesse conto será a reprodução de sua posição naquela sociedade rural e a impressão que se tem após a leitura é que o conto acaba refletindo sobre essa figura e o seu trabalho doméstico o mesmo olhar que essa sociedade patriarcal lança sobre ele, indiferente e sem complacência.

Por questões pessoais ou contingentes, as figuras femininas quando aparecem nas narrativas de Veiga reproduzem, então, em larga medida, o papel que a sociedade rural e patriarcal, matéria do escritor, estabelece para a mulher: dona de casa, mantenedora da ordem doméstica, mãe zelosa, esposa compreensiva, etc. Talvez num único conto ("Uma pedrinha na ponte") essa configuração não ocorra; um conto, aliás, também de características realistas e com um sabor machadiano inconfundível, mas essa exceção não desfaz inteiramente a regra. 


\subsection{A usina atrás do morro $e$ O galo impertinente}

Um conto que não se pode deixar de comentar é o já citado $A$ usina atrás do morro. O texto, aliás, é importante para toda a obra de Veiga na medida em que é reconhecidamente a matriz de dois dos livros posteriores, a novela $A$ hora dos ruminantes e o romance Sombras de reis barbudos. Além disso, o conto inaugura uma temática que se fará constante ao longo das obras do escritor, o tema da invasão, que ganhará outras e inovadoras configurações, seja como a máquina que é entregue por engano numa pequena cidade ou como a auto-estrada que é construída mediante a destruição da natureza ocasionando o desequilíbrio do ambiente.

Em A usina atrás do morro um garoto narra a chegada de um casal de estrangeiros à sua pequena cidade. $\mathrm{O}$ casal é reservado e avesso a qualquer tipo de 
contato com os moradores e a presença deles dá início a uma estória onde o insólito se infiltra sutilmente até se concretizar de maneira violenta, levando os moradores a uma situação limite de opressão, terror e morte.

Esse casal de estrangeiros, como já foi apontado pela crítica, é o representante de um novo modo de vida, representante do moderno, com suas máquinas e linguagens incompreensíveis, cercado de mistério e que lança olhares a tudo a sua volta com novas e outras intenções. Mesmo demonstrando pouca atenção às pessoas do lugar, os estrangeiros conseguem impor seus interesses oferecendo para alguns moradores, emprego, salário e motocicletas que se transformarão em máquinas assassinas, atropelando gente e animais indiscriminadamente.

Em pouco tempo quem impõe as regras na cidade é a Usina, a Companhia, que altera drasticamente a natureza, a vida e os valores dessas pessoas que em sua maioria se resignam e lamentam a perda de um tipo de vida, um tipo de mundo, que já não existe mais. Ao final do conto, esfacelado o núcleo familiar e a resistência possível, o narrador e sua mãe partem sorrateiramente "sem dizer adeus a ninguém, levando só a roupa do corpo e um saquinho de matula, como dois mendigos." 13

Uma sucinta comparação entre o núcleo do enredo desse conto e o das narrativas que retomam o tema pode ilustrar, além da similaridade já apontada, alguns traços que os distinguem, para que se possa, inclusive, procurar entender a necessidade histórica e/ ou estética da repetição do tema.

Em A hora dos ruminantes, a cidade a ser invadida tem nome, Manarairema, que, segundo Agostinho de Souza, seria algo como pequeno lugar sob espreita. ${ }^{14}$ Apesar de possuir nome o espaço se configura carente de outros atributos: o meio de transporte mais comum é a carroça ou o cavalo, diferente do que ocorre na cidade do

\footnotetext{
${ }^{13}$ VEIGA, José J. Os cavalinhos de Platiplanto. 15 a ed. São Paulo, DIFEL, 1985, p. 26.

${ }^{14}$ SOUZA, Agostinho Potenciano de. Um olhar crítico sobre o nosso tempo: uma leitura da obra de José J. Veiga. Campinas, Editora da Unicamp, 1990, p. 78.
} 
conto em que mesmo um dos moradores da cidade já possui um caminhão. Além disso, se percebe nessa última cidade elementos que a configuram como um espaço já de uma organização social básica com seus representantes oficiais (o delegado) e com uma estrutura de serviços mínima (a pensão em que se hospedam os estrangeiros, a agência dos correios). Em Manarairema se ressalta o caráter familiar da coletividade, aparentemente regida por um forte laço comunitário ainda isento de qualquer administração burocrática que se sobreponha.

Outra distinção entre as duas narrativas diz respeito à posição do narrador e a configuração do elemento estranho. Em $A$ hora dos ruminantes o foco narrativo é em terceira pessoa e embora se caracterize pela onisciência, sofre a mesma limitação de visão sobre as ações dos estranhos que se constata no conto. Isso ocorre porque esse narrador limita sua onisciência aos espaços da comunidade manarairense, posicionandose estrategicamente a partir do ponto de vista do coletivo, passível às limitações que se apresentam para essa coletividade. Uma dessas limitações é a justamente a configuração dos invasores, que se mostram esquivos e hostis sem incentivar nenhum tipo de contato e sem esclarecer sua natureza que apenas se deixa perceber ao final da trama. Como esse narrador não abdica de sua posição, nem mesmo acompanhando os poucos personagens que estabelecem contato com os estranhos, o leitor acaba compartilhando durante toda a narrativa o mesmo ponto de vista limitado e desfocado devido à distância escolhida pelo narrador.

Em A usina atrás do morro como se viu, o elemento estranho é identificado desde o primeiro momento como estrangeiro e suas intenções, embora escusas, se mostram perceptíveis para o leitor e dedutíveis para os personagens no correr da trama. Nesse sentido, as mudanças que os estrangeiros trazem já vêm representadas com a marca do fator econômico desenvolvimentista, explicitada na caracterização dos 
estrangeiros como técnicos, detentores de um saber científico e de maquinário de exploração do solo que serão responsáveis diretos pelos fenômenos de incêndio das casas. Assim, o conto é uma daquelas narrativas em que o elemento fantástico/insólito inexiste; o tratamento dispensado baseia-se numa representação de características realistas na qual o elemento insólito pode ser visto como produto direto de um conflito de culturas, como informa Fábio Lucas:

(...) seu texto explora mais comumente o conflito de culturas, quando os elementos da civilização, representados por avanços técnicos, são recebidos como estranho e misterioso. ${ }^{15}$

No conto, mesmo que o narrador seja em primeira pessoa e mesmo se tratando de um garoto, o grau de mediação para com o objeto narrado é maior comparativamente a $A$ hora dos ruminantes. Neste último, a descentralização da posição do narrador faz com que se diminua essa distância entre a voz narrativa e o objeto. Porém, ao efetuar esse movimento o narrado traz para si uma limitação de visão que o impede de se aproximar e enfocar objetivamente os estranhos invasores. Aqui ocorre o que afirma Anatol Rosenfeld:

Ao desaparecer o intermediário (...) desaparece também a ordem lógica da oração e a coerência da estrutura que o narrador clássico imprimia à seqüencia dos acontecimentos. Com isso esgarça-se, além das formas de tempo e espaço, mais uma categoria fundamental da realidade empírica e do senso comum: a da causalidade (lei de causa e efeito), base do enredo tradicional, com seu encadeamento lógico de motivos e situações, com seu início, seu meio e seu fim. Tais modificações (...) implicam uma retificação do enfoque: o narrador no afã de apresentar a "realidade como tal" e não aquela realidade lógica e bem comportada do narrador tradicional, procura superar a perspectiva tradicional, submergindo na própria psíquica da

\footnotetext{
${ }^{15}$ LUCAS, Fábio. Razão e emoção literária. São Paulo, Duas Cidades, 1982, p. 43.
} 
personagem ou tomando qualquer posição que lhe parece menos fictícia que as tradicionais e "ilusionistas". ${ }^{16}$

É nesse sentido que $A$ hora dos ruminantes parece dar um passo adiante na evolução formal do escritor. Para representar de maneira realista uma específica e recorrente matéria, o narrador se vê na necessidade de abdicar da sua posição de pretensa objetividade para colocar-se juntos dos personagens com uma visão nublada pelas contingências sócio-culturais, geográficas e econômicas, evitando, com isso, uma reprodução cuja função seria a de reforçar visões pré-concebidas sobre o objeto. Como diz Adorno:

Se o romance quiser permanecer fiel à sua herança realista e dizer como realmente as coisas são, então ele precisa renunciar a um realismo que, na medida em que reproduz a fachada, apenas a auxilia na produção do engodo. ${ }^{17}$

Em A usina atrás do morro, a técnica do realismo tradicional utilizada pelo narrador toma conhecimento das transformações da nossa época apenas na sua temática, pois sua forma ainda está atrelada de certa maneira à reprodução da fachada.

Outro conto que merece ser mencionado aqui é "O galo impertinente", de A máquina extraviada. O texto é evidentemente uma narração alegórica, uma fábula: um narrador em terceira pessoa conta sobre a construção de uma auto-estrada que consome gerações de engenheiros e trabalhadores, de modo similar ao que ocorre em "O Edifício", de Murilo Rubião. Após a inauguração algo estranho começa a acontecer: os

${ }^{16}$ ROSENFELD, Anatol. "Reflexões sobre o romance moderno". In Texto/Contexto I. $5^{\mathrm{a}}$ ed., São Paulo, Perspectiva, 1996, p. 84.

17 ADORNO, Theodor. W. "Posição do narrador no romance contemporâneo". In Notas de Literatura I. Tradução e apresentação de Jorge de Almeida. São Paulo, Duas Cidades; Ed. 34, 2003, p. 57. 
usuários da rodovia são atacados por um galo de grande porte, embora de tamanho não definido, que salta sobre os carros chegando a perfurá-los com o bico. Apesar de todas as providências e incursões do governo, inclusive com armamento de guerra, nada consegue dar fim ao animal, o que acaba por inutilizar para sempre a auto-estrada. $\mathrm{O}$ final do conto é saborosamente irônico:

Ninguém quis mais usar a estrada, ela foi ficando esquecida e hoje é como se nunca tivesse existido. Se um dia uma raça de homens novos derrubar a mata que lá existir, certamente notará aquela trilha larga coberta de capim e plantas rasteiras; e investigando mais abaixo descobrirá a capa de asfalto, os túneis, as pontes, os trevos e tudo o mais, e não deixará de admirar a perfeição com que se construíam estradas em nosso tempo. (...)

Quanto ao galo impertinente, se ainda existir, seria interessante saber que explicações os descobridores encontrarão para ele e que fim the destinarão - mas isso, reconheço, é uma indagação que está muito além do alcance atual da nossa imaginação. ${ }^{18}$

A maioria dos estudos sobre o texto se utiliza do conceito de alegoria desenvolvido por Walter Benjamin, obviamente pelo caráter valorativo que o filósofo imprime a esse conceito. Em seu livro Origem do drama barroco alemão, Benjamin expõe o que lhe parece ser um abuso ou um mal entendido 'injustificável' entre símbolo e alegoria:

(...) O que chama a atenção no uso vulgar do termo [símbolo] é que esse conceito, que aponta imperiosamente para a indissociabilidade de forma e conteúdo, passa a funcionar como uma legitimação filosófica da impotência crítica, que por falta de rigor dialético, perde de vista o conteúdo, na análise formal, e a forma, na estética do conteúdo. Esse abuso ocorre sempre que numa obra de arte a "manifestação" de uma "idéia" é caracterizada como "símbolo". (...) ${ }^{19}$

${ }^{18}$ VEIGA, J. J. A máquina extraviada. $3^{\text {a }}$ ed., Rio de Janeiro, Civilização Brasileira, 1976, p. 69.

19 BENJAMIN, Walter. Origem do drama barroco alemão. Tradução, apresentação e notas de Sérgio Paulo Rouanet. São Paulo, Brasiliense, 1984, p. 182. 
Esse percurso de valores e opiniões contraditórias sobre alegoria é bem ilustrado no capítulo inicial do livro de João Adolfo Hansen:

[No Romantismo] o símbolo passa a ser violentamente oposto à alegoria. Confundida numa só - $a$ alegoria - é então conceituada como particular para o universal (Schelling, Goethe), como invólucro ou revestimento exterior de uma abstração. Segundo os românticos, o símbolo que a tradição antiga, greco-latina, medieval e renascentista não distinguia da alegoria - é uma espécie de paradigma ou classe da qual ele é o único elemento. Por isso, sua significação é sempre imediata: em sua particularidade, ele contém ou expressa o geral. (...) Oposta a ele, a alegoria é teorizada como forma racionalista, mecânica, árida e fria. Retoricamente, a alegoria diz $b$ para significar $a$, (...) observando-se que os dois níveis são mantidos em correlação virtualmente aberta. ${ }^{20}$

Hansen identifica nesse movimento de desvalorização da alegoria pelos românticos, certas características peculiares do movimento:

Assim, os românticos postularam que a alegoria é exterior ao pensamento pretendido (...) Dado o intuitivismo e expressivismo da poética romântica, a alegoria só poderia ser considerada forma inferior do conceito, pois temporalmente sucessiva. (...) As noções românticas da arte como expressão incondicionada do artista-gênio em contato fulminante com potências cósmicas levavam a descartar a alegoria pelo seu caráter evidente de convenção retórica.

Com origens no Romantismo, essa distinção foi reforçada no século XX pelo pensamento marcante de Georg Lukács, vigorando como tema fecundo de discussões até os nossos dias. Mas para Hansen, a concepção lukácsiana ainda mantém a distinção equivocada entre alegoria e símbolo estabelecida no romantismo. Lukács observa:

Enquanto categoria estética - ela própria muito problemática - a alegoria dá, com efeito, uma expressão estética a certas concepções do

${ }^{20}$ HANSEN, João Adolfo. Alegoria: construção e interpretação da metáfora. São Paulo, Atual, 1986, pp. 5-6. 
mundo, cujo caráter é justamente o de dissociar o mundo, fundamentando-o numa transcendência essencial, cavando um abismo entre o homem e o real. Se a alegoria, enquanto orientação de estilo, é esteticamente tão problemática, é porque implica, no artista, uma concepção de mundo que recusa, por princípio, o mundo terreno (...) ${ }^{21}$

Para Hansen, a concepção de Lukács generaliza para toda alegoria as características de um determinado e peculiar tipo de alegoria, cujo uso foi limitado a uma época e a um pensamento específico:

Lukács julga a alegoria um modo inferior e superado de formar - ela é própria das artes da Transcendência, isto é, das artes cujo sentido está dado fora delas, na Eternidade, segundo ele. Tal concepção significa que o artista contemporâneo é formalista, quando alegorizante, pois opera com uma forma vazia a que não mais corresponde nenhuma transcendência num mundo de fragmentos e mercadorias ou, ainda, porque propõe reacionariamente a transcendência num mundo em que ela é ideologia. (...) falando em nome de um dever-ser da arte engajada na representação orgânica, isto é, realista, segundo seus parâmetros, Lukács generaliza para toda alegoria o que historicamente se aplicaria apenas à alegoria medieval. ${ }^{22}$

Para Walter Benjamin, a alegoria é "expressão, como a linguagem, e como a escrita" ${ }^{23}$. Nesse sentido "O galo impertinente" surge como uma escrita alegórica de singular valor na medida em que flagra com felicidade mais um instante do contato, configurado como conflito, entre culturas. Nele o povo uma vez mais é deixado à margem no processo de desenvolvimento de um lugar, vigiado pelos homens fardados e proibido de chegar perto da estrada no dia da inauguração. Novamente a oposição geográfica reflete a limitação do acesso ao novo imposta às massas pelas autoridades.

\footnotetext{
${ }^{21}$ LUKÁCS, Georg. Realismo crítico Hoje. Brasília, Coordenada-Ed. de Brasília, 1969, p. 66.

${ }^{22}$ HANSEN, J. A. Op. cit., p. 8.

${ }^{23}$ BENJAMIN, W. Op. cit., p. 184.
} 
Neste caso, um avanço técnico, o que reforça a analogia com o fetiche que os bens tecnológicos de consumo causam à população em geral nos nossos dias.

Outro elemento suscetível aos desmandos das autoridades no conto é o meio natural, a natureza. Ela é tratada da mesma maneira que é tratado o povo, como coisa a ser usada sem merecer nenhuma atenção responsável e minimamente respeitosa. A estrada, por causa do galo, se torna uma ruína, um grande monumento tecnológico sem serventia, seja para população local, seja para qualquer outra pessoa. É possível relacionar a construção dessa auto-estrada aos tantos e novos caminhos de acesso às grandes cidades que se projetavam no Centro-Oeste, como Goiânia e Brasília. Aliás, por uma simples questão de datas, é até mesmo provável que a referência mais correta seja essa mesma. Porém uma das lembranças mais recorrentes à leitura do conto é a construção da malfadada BR-230 ou Rodovia Transamazônica, com tudo o que ela representou e continua representando de desperdício do dinheiro público e de vidas humanas, de desrespeito ao cidadão, de desequilíbrio ambiental e de inutilidade para o população.

A ironia quase sarcástica no final do conto reflete em certo sentido a desconstrução da mensagem ideológica de país do futuro sugerida pelas excelências das técnicas e equipamentos apresentados para a construção da estrada, mensagem difundida por tantos governos, autoritários ou não, que mantiveram e mantêm o povo afastado dos bens e avanços tecnológicos que já são ruínas antes de existirem.

Ao utilizar a alegoria do galo que ataca os usuários da rodovia, Veiga consegue dar expressão aos excluídos do processo histórico, a natureza e o povo, configurando mesmo o absurdo de uma mentalidade desenvolvimentista que pretensamente exclui o meio natural desse processo, ou o inclui como fonte inesgotável de recursos, sem reciprocidade de benefícios, que, diga-se de passagem, produziu o estado de 
desequilíbrio social e ecológico em que hoje vivemos. Daí a forte ironia no final; através dela, o narrador demonstra possuir o que Antonio Candido chamou de "consciência dilacerada do subdesenvolvimento." 24

A narrativa, nesse sentido, ao invés de ser lida como um conto de características fantásticas, talvez ganhe maior significado e maior importância quando interpretada como uma mensagem alegórica: o galo como indício das forças da natureza que se volta, ou se revolta, contra o homem. Porém, devido à atual situação do planeta e o que se projeta para o futuro, é possível que a contundência da representação possa ir perdendo a força com o passar do tempo, na medida em que vamos cada vez mais conhecendo empiricamente, e não somente através da literatura, a profundidade da alteração da natureza causada pelo homem e conhecendo as respostas dela em forma de catástrofe.

Por último uma informação que soa irônica: em 1998, o Estado de Goiás, em homenagem ao escritor, deu a rodovia estadual GO-225, que liga Corumbá de Goiás a Goiânia, o nome de Rodovia José J. Veiga.

${ }^{24}$ CANDIDO, Antonio. "Literatura e subdesenvolvimento". In: A educação pela noite \& outros ensaios. São Paulo, Ática, 1987, p. 161. 


\section{ADEQUAÇÃO E IMPASSES DE UMA NARRATIVA}

\subsection{Reificação e subserviência: as fissuras do solo}

Nas primeiras obras de José J. Veiga um dos temas constantes é o da invasão, cujo desenvolvimento se pode acompanhar, por exemplo, em narrativas como $A$ usina atrás do morro, A hora dos ruminantes, Sombras de reis barbudos, A máquina extraviada e $O$ galo impertinente. Mesmo em obras posteriores esse tema parece retornar, embora estilizado em enredos singulares dentro da produção veiguiana, como no romance histórico $A$ casca da serpente em que os invasores são as forças legalistas republicanas na iminência de tomarem de assalto o arraial de Canudos, ou em Torvelinho dia e noite, com a invasão, desta vez positiva, de um casal de fantasmas que vem trazer bons fluidos e serenidade a uma pequena cidade do país. 
As três primeiras narrativas citadas, A Usina atrás do morro, A hora dos ruminantes e Sombras de reis barbudos, além da correlação temática, possuem mesmo um enredo muito semelhante embora sejam narradas em gêneros distintos, figurando explicitamente em alguns momentos os invasores como representantes de uma nova ordem baseada no capital industrial que parece trazer o desenvolvimento tecnológico às pequenas e distantes cidades, ao mesmo tempo em que dilacera abruptamente as relações sociais do lugar e implanta um clima de terror. Em outro momento essa representação sugere uma intromissão difusa e ambígua que embora aja de maneira concreta, não se mostra, ou não é contada, objetivamente, num estranhamento ainda mais intenso dada a opacidade da visão.

A hora dos ruminantes conta a história da chegada de um grupo de homens na distante e pequena cidade de Manarairema, em um interior brasileiro não especificado. Essa chegada e a relação que os homens visam estabelecer com os moradores da cidade são envoltas numa atmosfera de estranheza, desconfiança e arrogância que se avolumam para a opressão e o horror na forma de invasões de animais: a primeira, a invasão de cachorros, subjuga a população através da humilhação da qual os habitantes só têm consciência após o sumiço dos bichos. A segunda invasão, a dos bovinos, submete a população a uma situação esmagadora de terror numa inversão dos papéis de animais e homens no mundo.

A narrativa se divide em três capítulos, "A chegada", "Os cachorros", "Os bois", cujos nomes já indicam a seqüência dos aparecimentos estranhos. Os capítulos possuem certa identidade estrutural apesar da assimetria na extensão. De qualquer maneira, em todos os três capítulos ocorre um fato fora do comum que atrai para si os olhares e as atenções, e a partir do qual se desenrolam as ações. Portanto, os capítulos se estruturam 
em torno de cada um desses acontecimentos que funcionam como pontos focais dentro da narrativa e que são responsáveis, de certo modo, pelo desenvolvimento dela.

A história é contada por um narrador em terceira pessoa cuja onisciência é limitada aos espaços da comunidade não utilizados pelos estranhos. Dentro do espaço coletivo esse narrador se move com segurança servindo-se de um discurso indireto livre que aplicado aos personagens configura a visão da coletividade. A sintaxe simples, a frase concisa, o uso comedido e específico de um léxico mais local, constroem uma oralidade sem artificialismos que é auxiliada, em certa medida, pelo fato do narrador partilhar, ou fingir partilhar, não só do ponto de vista, mas dos mesmos sentimentos, opiniões e referentes da coletividade de Manarairema para pensar o mundo e as relações humanas.

Em $A$ hora dos ruminantes a estória das invasões começa num fim de tarde quando parte da população identifica ao longe uma trupe de cavalos e burros de carga descendo a estrada e se aproximando da cidade, lugar de passagem obrigatória para quem fazia aquele percurso. Passados alguns instantes com conversas de temas variados, da carestia e falta de alimentos à discussão sobre a possibilidade do fim do mundo, constata-se que os cargueiros não apareceram. $\mathrm{O}$ fato dessa chegada não se concretizar no tempo esperado deixa alguns habitantes confusos e frustrados, pois além da expectativa do contato com gente de fora, havia também a esperança de que os viajantes trouxessem produtos escassos momentaneamente na região, como o sal e o toucinho de porco.

O sentimento de incerteza quanto à existência dos cargueiros faz, inclusive, alguns moradores reconsiderarem a impressão de tê-los vistos anteriormente, e embora aceitem explicação pouco plausível, todos se recolhem às suas casas, ressabiados com o episódio pouco compreensível. Esse espanto irá aumentar quando, no dia seguinte, se 
constata a surpresa: "um grande acampamento fumegando e pulsando do outro lado do rio, coisa repentina, de se esfregar os olhos" ${ }^{25}$. A novidade do acampamento silenciosamente instalado de madrugada, depois do negaceio dos estranhos em estabelecerem um primeiro contato, faz com que a população se mantenha precavida, como quem pressente que há algo diferente no ar, ou como quem repara que os fatos parecem acontecer sem seguir a ordem costumeira. Desde o momento, pois, em que aparecem para os manarairenses, ainda descendo a serra, entre a vegetação, num final de tarde, já no terceiro parágrafo inicial da história, os viajantes se mostram premeditadamente esquivos, frustrando a expectativa de um contato cordial aguardado pelos moradores, sensação intensificada pela montagem do acampamento às escondidas.

Duas notações são importantes nesses primeiros momentos da narrativa: a primeira delas diz respeito à falta de alimentos básicos para a população de Manarairema, o que já nos serve como indicativo dos problemas nesse lugar que começa a ser configurado pelo narrador. A segunda notação se refere à própria expectativa, por parte da população, do contato cordial com os visitantes, expectativa que parece dizer de experiências similares ocorridas anteriormente, sugerindo que o aparecimento de forasteiros e viajantes não fosse incomum naquelas paragens.

O que é incomum e desconcertante para a população, isso sim, é essa chegada envolvida num clima de incomunicabilidade arredia que se expressa na maneira subreptícia da armação do acampamento. A população de Manarairema fica num misto de curiosa e ofendida nos seus brios de anfitriã dispensada e enquanto parte dela decide retribuir idêntica postura muda e indiferente, uma maior quantidade de moradores permanece atenta aos movimentos do acampamento, a vigiar os estranhos na intenção de se obter alguma informação que explicasse aquela presença repentina.

\footnotetext{
${ }^{25}$ VEIGA, José J. A hora dos ruminantes. $28^{\text {a }}$ edição, Rio de Janeiro, Bertrand Brasil, 1993, p. 4.
} 
E assim inicia-se a história das invasões em Manarairema, estabelecendo já desde o início um clima de mistério e tensão entre os dois agrupamentos humanos. A atitude dos forasteiros, de negacear uma aproximação diplomática e mais condizente aos costumes locais, irá gerar um desconforto crescente na população, alterando gradativamente a disposição amigável de boas vindas para um sentimento de profunda aversão. A mudança de receptividade tem como motivo dois instantes bastante significativos nessa parte inicial da história.

O primeiro desses momentos, o encontro do padre com os estranhos, estabelece como característica fundamental deles, uma ausência absoluta de sociabilidade no trato pessoal e uma evidente indiferença para com os usos e costumes ligados à religiosidade daquele povoado, indiciando com isso além da falta no trato pessoal também a falta de convivência com esses símbolos religiosos, assim como a ausência de funcionalidade dessas representações simbólicas no cotidiano desses forasteiros.

O atrito, ou melhor, a exasperação da situação se dá justamente pelo desdém dos estranhos e a ausência de reverência frente a uma figura tradicionalmente tratada com respeito e formalidade dentro dos costumes e tradições locais. É evidente que essa indiferença é uma grosseria mesmo com o ajudante do padre que o acompanha, por serem os estranhos meros forasteiros que estão invadindo o espaço dos moradores do lugar; mas esse desprezo relacionado ao vigário ganha dimensões de ofensa na medida em que ele detém certo grau de autoridade local como representante religioso.

Outro momento determinante para a mudança de recepção possui também a questão do trato pessoal como motivo central. É o instante do encontro entre um dos forasteiros e o carroceiro Geminiano Dias, personagem dos mais importantes da história e, sem dúvida, aquele que mais diretamente sofre os efeitos da estranha visita. É através dele que ocorre o primeiro contato verbal com os forasteiros. O estranho interpela 
Geminiano com certa autoridade no tom da voz, de maneira pouco simpática ou amigável, o que resulta em diálogo áspero e desafiador, numa cena que concretiza o que era até então apenas prenúncio de um embate de forças.

O ritmo da narrativa é ágil na medida em que o narrador mantém sempre em primeiro plano os acontecimentos do enredo e as ações de cada personagem, detendo-se muito pouco e apenas à maneira de pinceladas em descrições periféricas dos cenários ou na descrição física dos protagonistas. Econômico, o narrador pretende, nesse início da narrativa, caracterizá-los, cenários e personagens, no exato instante em que são chamados ao enredo, deflagrando situações de significação. Na cena do carroceiro e do forasteiro a proposta deste último é comprar a carroça, instrumento de trabalho e sobrevivência de Geminiano, proposta prontamente rechaçada. Devido à insistência do estranho através de falas impositivas e já agora autoritárias, Geminiano se exalta e encerra a conversa de maneira abrupta "deixando o homem apatetado na beira da estrada." 26

A notícia deste acontecimento rapidamente se espalha pela cidade, e o carroceiro recebe elogios dos conterrâneos pelo justo tratamento dado ao sujeito: "Então aquilo era maneira de tratar negócio, falando de cima, e metendo a mão, e dando ordem, como se eles fossem donos de tudo?" ${ }^{27}$ Do mesmo modo como ocorrera na chegada à cidade e no encontro com o padre, os forasteiros se mostram pouco afeitos a uma relação de mais civilidade ou uma relação mais paritária nas formas de tratar o outro; as relações de alteridade, então, aparecem como motivo condutor inicial na trama ao mesmo tempo em que ganham importância para uma caracterização mais precisa, se não dos dois, pelo menos de um dos agrupamentos que agora se espreitam.

\footnotetext{
${ }^{26}$ Op. cit., p. 8 .

${ }^{27}$ Op. cit., p. 7.
} 
Assim, as formas de tratamento se destacam aqui porque servem para caracterizar Manarairema como uma dessas cidades do extenso interior do país que serão matéria persistente na obra do escritor. Como já indicara o pioneiro estudo de Samira Campedelli,

O mundo que J. J. Veiga traz para as páginas de seus livros retrata bem esse povo das "cidades miúdas", como ele fala. Povo que ainda não foi atingido em cheio pela dita civilização moderna e sequer ouviu falar em capitalismo. E, paradoxalmente, trabalha para ele: é esse povo que toca os latifúndios, planta a terra, tange o gado. ${ }^{28}$

Característica destacada desde o início pela crítica, boa parte dos contos e dos romances de Veiga tem como cenário esses espaços interioranos, vilas, lugarejos, cidadelas, cujo aspecto íntimo e familiar ainda parece regular de maneira determinante a vida da população. No entanto, na maioria das vezes, esses lugares aparecem já configurados num movimento de transição, de mudança, representado pelo surgimento de um evento novo que é visto, da perspectiva dos habitantes desses locais, sempre como algo envolto num halo de incompreensão e estranhamento.

É assim, por exemplo, que Alfredo Bosi caracteriza a literatura de Veiga:

O autor dos Cavalinhos de Platiplanto encrava situações de estranheza em um contexto familiar, que evoca discretamente costumes e cenas regionais. ${ }^{29}$

Sinteticamente Bosi revela os aspectos de maior importância nas principais histórias de Veiga, além de indicar a face do fantástico que irrompe delas; "como o intruso no ritmo do cotidiano":

\footnotetext{
${ }^{28}$ CAMPEDELLI, Samira Y. José J. Veiga. Col. Literatura Comentada, São Paulo, Abril, 1982, p. 95 .

${ }^{29}$ BOSI, Alfredo. "Situação e formas do conto brasileiro contemporâneo". In: O conto brasileiro contemporâneo. $3^{\mathrm{a}}$ ed., São Paulo, Cultrix, 1978, p. 20.
} 
(...) o evento novo, que poderia soar apenas imprevisto e aleatório, passa a exercer, na estrutura profunda da trama, a função de revelador de um processo inexorável na vida de um grupo. ${ }^{30}$

Apesar de escassas e intensamente elaboradas pela invenção, enquanto ato estético, as indicações de tempo e lugar são consistentes na caracterização e contextualização de Manarairema; como identifica Agostinhos de Souza,

Situadas em um interior brasileiro pouco antes dos anos 50, estas cidades passam a representar, a parcializar uma face do Brasil que sofre os golpes do mito do progresso do século XX, progresso que esfarela alguns aspectos tradicionais da cultura brasileira. ${ }^{31}$

Aspectos positivos e negativos, é bom que se diga. Assim é que Manarairema toma a aparência daqueles lugares longínquos, dos quais ressaltam as figuras que vão compondo a feição da comunidade: o latoeiro, o padre e seu ajudante, o carroceiro, o comerciante, o caçador, o moço do cartório, o marceneiro, o ferreiro, o coronel da região etc. Um lugarejo ainda sem a presença efetiva do estado, uma localidade pautada ainda nos relacionamentos pessoais, sem uma liderança institucionalizada. Percebe-se, no entanto, que essa representação não é ingênua a ponto de insistir numa simples polarização entre um local ameno e um invasor estrangeiro do mal.

Desde o início, como já foi dito, a voz narrativa deixa evidente os indícios de que o espaço da cidade se trata de um espaço problemático com carências e atritos conjunturais, impossível de ser pensado meramente como positivo numa relação polarizada com os estranhos. E é assim que Manarairema, mesmo se configurando como aquele que sofre a ação obscura e difusa de um grupo de forasteiros 'invasores'

\footnotetext{
${ }^{30}$ Op. cit. p., 20.

${ }^{31}$ SOUZA, A. P. de. Op. cit. p., 71.
} 
com finalidades e comportamentos questionáveis, também vai se configurando como um cenário trincado, com suas contradições peculiares e profundas.

O tamanho das fissuras no solo de Manarairema começa a ficar mais visível para o leitor logo após os elogios da maioria dos habitantes ao carroceiro pelo seu comportamento com o estranho que tentara comprar a carroça à força. Isso porque em meio às vozes de apoio há uma de discordância que se faz mostrar virulenta e agressivamente. É a voz de Amâncio Mendes, comerciante, dono de uma mercearia que é um dos pontos de encontro dos moradores da cidade e ambiente recorrente em todo o enredo. A estratégia do narrador é a mesma já apontada, o personagem se apresenta por si, com suas palavras e atitudes:

- Esse tição é muito besta. Só porque arranjou uma carroça pensa que virou gente. Havera de ser comigo. ${ }^{32}$

Somente a partir da ofensa gratuita e constrangedora de Amâncio é que o leitor fica sabendo que Geminiano é negro e a relevância deste fato aparece mesmo no procedimento narrativo de estabelecer a informação na fala do personagem, em discurso direto, e não no discurso indireto do narrador. A força da frase elimina as dúvidas sobre uma das ideologias presentes na comunidade manarairense, além de intimidar de maneira autoritária os espantados interlocutores do comerciante que tentavam timidamente defender o carroceiro.

Desde o momento em que aparece na trama, o comerciante Amâncio Mendes opta por tomar partido dos estranhos, mesmo que isto represente se postar de maneira contrária à maioria de seus conterrâneos. É certo que o próprio Amâncio não atina totalmente com as conseqüências de sua adesão na medida em que também não tem muito claro para si o sentido dessa obscura presença, mas como homem do comércio,

\footnotetext{
${ }^{32}$ VEIGA, José J. Op. cit., p. 8.
} 
do capital, sempre aberto a idéias novas, sua atitude é de imediatamente ser contrário ao carroceiro e apoiar o estranho.

Percebe-se com isso que o atrito entre carroceiro e vendeiro não é uma oposição criada externamente, ela antecede a presença dos estranhos; e ao descrever de maneira mais detalhada as figuras de Geminiano e Amâncio, o narrador amplia a percepção da distância e das diferenças entre os dois na medida em que evidencia não só as distinções pessoais, mas também a origem e as características de inserção social de cada um: enquanto Amâncio é oriundo de família de uma certa classe mediana, de pouca ou nenhuma posse, mas com um passado de pessoas livres, Geminiano tem na sua ascendência familiar a marca da escravidão.

Conhecidos por todos nós, as figuras peculiares do trabalhador braçal, vivendo de expedientes, de origem humilde, herdeiro de uma herança escravista recente no contexto do enredo e profundamente marcante na sociedade brasileira, e do pequeno negociante, ligado à atividade e ao comércio livre, práticas de uma ideologia que traz em seu lema a palavra igualdade como centro, essas figuras se apresentam aqui numa oposição tensa e iminentemente violenta.

Neste momento de tensão surge uma vez mais a figura de padre Prudente, cuja intervenção é fundamental não só para desarmar o espírito de Geminiano, mas também para a construção de um discurso valorizando o comportamento reto e a importância, por todos comprovada, da atividade do carroceiro e de sua pessoa dentro do universo social de Manarairema, discurso que surge como contraponto à fala discriminatória e preconceituosa do comerciante Amâncio Mendes.

A existência dos dois discursos é importante também porque vai confirmando de maneira mais evidente o caráter ambíguo das idéias presentes no solo manarairense, ambigüidade possível de se constatar até mesmo na unilateralidade da intervenção de 
padre Prudente. Isso porque na tentativa de solucionar diplomaticamente as rusgas entre os dois personagens, o religioso exerce sua influência apenas sobre o lado mais fraco dessa polaridade, ou seja, sobre Geminiano Dias, conotando certa distância, falta de diálogo ou até mesmo certa impotência no trato com Amâncio Mendes.

Num primeiro momento após a leitura há uma tendência, talvez natural, de enxergar a personagem do padre como uma figura de certa autoridade em Manarairema, na medida em que é ele o representante do poder divino na terra e símbolo de uma visão, ainda de cunho mítico, sobre a realidade. Pelo fato de que Manarairema se apresenta como um lugarejo de características arcaicas, de certo aspecto familiar, sem a presença de autoridades formais, é possível que o leitor veja na figura do padre aquela autoridade típica desses lugares longíquos, que além da preocupação com a vida espiritual de seu rebanho era capaz também de interferir concretamente no comportamento individual de cada um.

Porém, nos três momentos em que possui algum destaque na narrativa, padre Prudente parece desmentir a idéia de autoridade que o leitor poderia ter a seu respeito: na primeira vez, no encontro com os estranhos, o padre sequer recebe um cumprimento dos homens, sendo até mesmo motivo de riso e algum deboche, como fica sugerido; na última vez, em meio à invasão asfixiante dos bois, o religioso se mostra de tal maneira impotente frente ao estado de coisas, que chega ao ponto de recusar o uso dos paramentos e os rituais de sua crença para exorcizar os animais, terminando por se trancar no quarto com sua coleção de selos, numa configuração explícita da impossibilidade de compreender e agir em meio ao desgoverno das coisas.

No caso do atrito entre Amâncio e Geminiano, a intervenção do padre só encontra eco neste último porque dos dois personagens é Geminiano quem se esforça para cumprir de maneira adequada o seu papel dentro da sociedade manarairense, 
conotando com isso o esforço de se fazer cidadão respeitável e ordeiro, cumpridor de seus deveres e merecedor dos direitos que aquele quadro social lhe oferece. Permeável à influência da palavra do padre, o carroceiro acredita e age baseado nos princípios, nas idéias que julga serem os parâmetros aceitos por todos para a convivência coletiva e a dignidade pessoal, os códigos sociais.

Como se vê, o personagem do padre é também ela caracterizada pela marca da ambigüidade que parece envolver aos poucos ambientes, personagens e atitudes. A última participação do religioso, impotente frente à invasão dos ruminantes, é cabal na figuração desse esvaziamento de autoridade do representante católico de Deus em Manarairema. Se essa autoridade ainda é capaz de se fazer ouvir por personagens como o de Geminiano, é tão somente porque apenas estes se mostram ainda imersos em um pensamento idealista, mítico e redentor, crentes integralmente em abstrações que nem sempre ganham a forma por eles idealizada e que muitas vezes conciliam elementos contraditórios sob uma camada opaca de normalidade ou naturalidade. Isso ficará evidente a partir do momento em que os forasteiros se apropriam de maneira monopolizadora do trabalho de Geminiano Dias sob o manto da aceitação, por parte deles, das regras estabelecidas pelo carroceiro para atendimento de seus clientes.

Mas a representação estética dessa alteração de significados de tipos que em outros contextos eram revestidos de autoridade não se dá apenas no nível da liderança religiosa. Ela ocorre também, embora de maneira mais sutil, quando enfoca as lideranças políticas, econômicas do local. A sutileza aqui sendo forma de um conteúdo que age em sentido contrário, dada sua importância. É que a autoridade de maior destaque no lugar é representada por uma ausência, através de um personagem, seu Júlio Barbosa, nomeado e qualificado como proprietário de terras, mas relacionado ao longo da narrativa como mais um dos tantos rostos a compor o quadro social do lugar. 
O leitor ficará ciente desse personagem não através do narrador, a quem já se olha com alguma desconfiança, mas sim pela fala do ajudante do padre na sua inocência servil:

(...) Pessoa correta estava ali, mas com ele ninguém brincava. Seu Júlio era desses que quando saem à rua limpam a cara de qualquer sorriso para desanimar brincadeiras, e quando dão bom-dia a alguém é como quem manda, e a pessoa passa o resto do dia preocupada, com medo de desobedecer. ${ }^{33}$

A maneira como o fazendeiro é descrito no início da narrativa dá a idéia exata de que tipo de pessoa é e a qual estrato social está relacionado. Com a autoridade de proprietário seu Júlio poderia intimar os estranhos a deixarem as terras sem ao menos dar direito de resposta aos invasores. A formulação dessa idéia supõe o fazendeiro como autoridade e liderança da população para agir em momentos como aquele, de apatia ou confusão coletiva.

Além disso, o que justifica a fala de Balduíno é o fato de que os estranhos montaram seu acampamento justamente dentro dos limites das terras do fazendeiro, ou pelo menos, que se julgava ainda pertencerem a Júlio Barbosa. Trata-se, portanto, de um latifundiário, homem acostumado ao mando cuja ligação com o solo, distintamente do que ocorre com os demais moradores da cidade, se dá no plano do acúmulo de bens e não da relação íntima e diária com o lugar; é um coronel ausente de suas terras, talvez próximo nesse instante dos centros urbanos do poder, numa fase de transição das esferas de liderança política e econômica. Sobre esse aspecto já observara Samira Campedelli:

No cerrado é possível vislumbrar manadas e manadas de gado pertencentes a grandes latifundiários, que raramente moram nas fazendas: estão sediados nos grandes centros e visitam o campo de quando em quando, na época da marcação do gado, na época da venda ou do abate. Contato com

\footnotetext{
${ }^{33}$ VEIGA, J. J. Op. cit., p. 9.
} 
a terra mesmo é com os peões, que trabalham de "ameia", cultivam a roça dos outros e depois repartem com o dono. ${ }^{34}$

A referência histórica, apesar da sutileza da representação, parece concreta aqui na medida em que sugere um momento muito significativo dos caminhos tortuosos da evolução sócio-econômica brasileira: a mudança das elites agrárias para o universo urbano e a conseqüente mudança de lideranças nos ambientes rurais com a posse da terra e alteração das relações sociais causada pela penetração de um capital mais forte que imprime sua marca indelével.

O personagem de Júlio Barbosa acaba representando não só por sua ausência na trama, mas principalmente pela ocupação de suas terras pelos estranhos forasteiros que chegam com a autoridade e o autoritarismo de novos mandatários, um momento significativo de um processo que no Brasil se iniciou em meados dos anos 40 e que foi chamado por alguns de "redemocratização", mas que na verdade foi outro momento em que as classes brasileiras mais ricas se utilizaram novamente do expediente da revolução "pelo alto", ou seja, uma mudança superficial para manter estruturalmente o mesmo estado de coisas, mais uma vez deixando as massas populares à margem dos processos dessa mudança. Talvez seja inadequado dizer outro momento, pois se trata do mesmo movimento que atingira antes o eixo economicamente mais adiantado do país e que se configura com atraso no lugar de mais atraso. Como afirma Carlos Nelson Coutinho:

(...) Aqui [no Brasil], a burguesia se ligou às classes dominantes, operou no interior de uma economia retrógrada e fragmentada. Quando as transformações políticas se tornavam necessárias, elas eram feitas "pelo alto", através de conciliações e concessões mútuas, sem que o povo participasse das decisões e impusesse organicamente a sua vontade coletiva. Em suma, o capitalismo brasileiro, ao invés de promover uma transformação social revolucionária (...) contribuiu, em muitos casos, para acentuar o

\footnotetext{
${ }^{34}$ CAMPEDELLI, S. Y. Op. cit., pp. 94-95.
} 
isolamento e a solidão, a restrição dos homens ao pequeno mundo de uma mesquinha vida privada. ${ }^{35}$

No conto A usina atrás do morro, que como já dissemos possui a base do enredo de $A$ hora dos ruminantes, esses dados históricos são explicitados não só na empresa do título, mas também na referência ao capital internacional representado pelo casal de estrangeiros como técnicos responsáveis pela verificação do lugar a ser explorado. Mesmo no livro de 1972, Sombras de reis barbudos, essa situação parece se repetir, desta vez já com todo aparato burocrático-administrativo de uma empresa, a Companhia Melhoramentos de Taitara, nome carregado de uma ironia que se verá cruel. Em $A$ hora dos ruminantes essas referências se apresentam de maneira mais sutil e mais embaralhada, numa atenta e densa correspondência entre conteúdo e forma literária, na medida em que a voz narrativa se posiciona a partir do ponto de vista da população, segundo uma ótica limitada e deformadora na sua impotência de vislumbrar os movimentos gerais que espreitam Manarairema.

É significativo, então, que os estranhos invasores se instalem justamente num espaço anteriormente ocupado por forças que agiam de modo a manter certa ascendência sobre os da terra. Mudando-se os dominadores, os dominados permanecem os mesmos, inconscientes das alternâncias no poder e dos rumos que serão tomados pelas novas lideranças, agora desconhecidas, distantes e misteriosas. Alienada dessa mudança pelo alto das esferas do poder local, a população de Manarairema se move neste terreno difuso e contraditório onde palavras e atos possuem significados muito peculiares e nem sempre perceptíveis à primeira vista. A ambigüidade se imiscuindo em todos os cantos, a cada passo, atingindo todos os personagens, todas as coisas.

\footnotetext{
${ }^{35}$ COUTINHO, Carlos N. "Graciliano Ramos”. In BRAYNER, Sônia (org.). Graciliano Ramos. Col. Fortuna Crítica, $2^{a}$ ed., Rio de Janeiro, Civilização Brasileira, 1978, p. 76.
} 
Assim quando mais à frente na história nos deparamos com Geminiano Dias trabalhando para os estranhos da tapera, o espanto é menos dos manarairense que do leitor. Para eles não é incongruente a atitude do carroceiro em servir, em trabalhar para os forasteiros na medida em que é justamente essa a atividade de Geminiano. Além disso, segundo a ótica tanto da população quanto do carroceiro, o fato de que os homens tenham se adequado ao procedimento do dono da carroça seria, por si, um indicativo da conformidade deles aos costumes locais e, portanto, tinham o direito de serem atendidos.

O que verdadeiramente começa a incomodar os manarairenses é o fato de não mais poderem contar com o serviço do carroceiro na medida em que o trabalho estabelecido pelos estranhos toma por completo o esforço operário de Geminiano já durante um mês inteiro sem que ele soubesse quando iria parar. O trabalho era simples: retirar areia da praia do rio e levá-la ao acampamento, pois os homens estavam fazendo grandes obras.

O leitor constata pouco a pouco que lhe fora sonegado um momento de grande interesse e tensão na história: o reencontro de Geminiano com os homens da tapera, reencontro agora, ao que tudo indica diplomático e pacífico, embora não haja nenhuma observação objetiva sobre este momento. O narrador, ao contrário do que ocorrera anteriormente, na cena do atrito, não se mostra como testemunha neste instante de acordo entre os estranhos e Geminiano, e ao leitor não é dada qualquer informação sobre este contato, nem de quem foi a iniciativa, nem em que termos se trataram.

Além da perda dos serviços do carroceiro a cidade agora tem outro problema em forma de dúvida e curiosidade: saber das atividades e intenções dos forasteiros. Para isso a reação dos moradores é interpelar Geminiano em todas as ocasiões em que ele passa indo ou retornando do acampamento na sua atividade contínua. Mas as respostas 
que o carriceiro pode fornecer são poucas, nada mais que pequenas observações sobre aspectos genéricos e superficiais da presença e das ações dos homens na fazenda, ou na ex-fazenda, de Júlio Barbosa.

Geminiano não tem tempo para essas observações e muito menos para contar o que sucede na tapera; ou seja, sendo o único personagem da história que, até o momento, tem acesso constante ao local onde estão instalados os estranhos, ele não esclarece nenhuma dúvida sobre o que se faz na chácara, que obras estão sendo construídas, quem eram os forasteiros, quais suas origens e intenções, etc, indicando a falta de contato e diálogo. Vítima de um trabalho extenuante, ele só consegue repetir os mesmos gestos mecânicos sem reparar na mudança da paisagem ao redor. O trabalho sem perspectiva final o toma por completo e a sua vida agora é aquela rotina diária de várias viagens entre o acampamento e o rio transportando areia, incapaz de sopesar as contradições de sua atitude e de perceber as ambigüidades geradas nas relações profissionais que estabeleceu com os forasteiros.

O manarairense Geminiano Dias, de trato fácil e ameno, carroceiro de profissão, bem quisto por quase todos da cidade, vai aos poucos se afastando dos círculos de suas relações pessoais substituindo-os, todos, por um outro, o da incessante e estéril labuta. Se, anteriormente, Geminiano se mostrou capacitado de relatar aos amigos o primeiro contato com um dos estranhos, e depois ainda fora capaz de argumentar com o padre o seu ponto de vista em relação à ofensa de Amâncio, neste momento, quando o ritmo natural da vida, assimilando e pautando os acontecimentos, deixa de vigorar e as coisas passam a ser feitas com a premência da contagem do tempo, a experiência comunicável se esvazia. Refém da sua própria conduta no atendimento aos clientes (os estranhos esperaram a vez para serem atendidos!), Geminiano não consegue mais se livrar do trabalho que os homens da tapera lhe impingem sem descanso, num monopólio semi- 
escravo em que não se vê o pagamento a que tem direito o carroceiro. Ou seja, a sua atividade, que era prestada a toda uma comunidade, e que ganhava características, locações e destinos diversificados a cada tipo de serviço, cumprindo uma função de valor social, torna-se um fazer exclusivista e monopolizado que desumaniza e tira do sujeito a capacidade de se incluir comunitariamente através do trabalho, tornando-os, homem e trabalho, meras peças do todo organizado de atividades autômatas.

Ao tratar do conceito de jornada de trabalho do ponto de vista do capitalismo, Marx afirma:

Entende-se por si, desde logo, que o trabalhador, durante toda a sua existência, nada mais é que força de trabalho e que, por isso, todo seu tempo disponível é por natureza e por direito tempo de trabalho, portanto pertencente à autovalorização do capital. Tempo para a educação humana, para o preenchimento das funções sociais, para o convívio social (...) pura futilidade! ${ }^{36}$

Portanto o contato de Geminiano com os estranhos traduz-se numa paulatina degradação da sua individualidade, personificando de maneira exemplar o processo de reificação que ainda mais contundente se torna dadas as condições prévias do arcabouço social do carroceiro. Esgotado pelo serviço monopolista e semi-escravo, esvaziado da sua humanidade, alheio ao produto e à finalidade da própria atividade, Geminiano tem a força de seu trabalho convertida em mercadoria, numa formulação clássica do processo capitalista que transforma o homem numa coisa.

Se inicialmente as características de Geminiano são todas positivas, um caráter íntegro, amigo de todos, cumpridor dos seus deveres, boa índole, etc., ao longo da narrativa, exigido pela premência do trabalho e vítima da sua própria conduta em relação aos que se propõem a alugar sua mão-de-obra, Geminiano vai se afastando das

${ }^{36}$ MARX, Karl. “A jornada de trabalho”. In O Capital. $2^{\mathrm{a}}$ ed., São Paulo, Nova Cultural, 1985, cap. VIII, p. 211. 
relações sociais que regem a vida comunitária, se afastando da própria capacidade de estabelecer comunicação com os seus pares, e não percebe a decomposição da sua personalidade à vista de toda a comunidade, decomposição dos laços que embora contraditórios vigoravam de maneira a fazê-lo sentir-se inserido comunitariamente.

Essa decomposição ficará evidente na cena em que o carroceiro, surpreendido por um problema de pequenas dimensões, se desequilibra emocionalmente e fora de si cai em prantos, causando a impressão nos que o assistem de que aquele Geminiano não era mais o mesmo, "O Geminiano antigo estava muito longe, muito sumido no fundo daquele que agora passava com a carroça, todos concordaram e lamentaram a falta dele." 37

Ciente agora de que os homens operavam grandes obras nos domínios de sua ocupação e impossibilitada de obter informações através de Geminiano Dias, a população fica a mercê da iniciativa do comerciante Amâncio Mendes que numa atitude peculiar decide visitar, enfim, o acampamento dos estranhos. A figura do vendeiro surge então com mais detalhes, se destacando entre os manarairenses como a representação mais forte da ambigüidade que rege toda a narrativa.

Desde o primeiro momento em que aparece no enredo esse personagem tem como marca registrada a arbitrariedade das ações, deflagrada quase sempre por um comportamento passional e impulsivo que o impede de avaliar criticamente suas palavras, causando, às vezes, momentos irreparáveis de comprometimento. Segundo um personagem menor da estória, Amâncio Mendes "era um cruz que Manarairema tinha de carregar com paciência" ${ }^{38}$. Sempre disposto a passar-se por valente, o vendeiro tinha a mania de "querer levar tudo em ponta de faca, de se ofender com qualquer reparo",

\footnotetext{
${ }^{37}$ VEIGA, J. J. Op. cit. p., 31.

${ }^{38}$ Op. cit., p. 11.
} 
um tipo que falava gritando, arrumava confusões "para sustentar fama de valente" e quando entrava "numa briga para apaziguar, acabava brigando com os brigões" ${ }^{39}$.

No entanto, na medida em que o próprio personagem já possui consciência de suas atitudes despropositadas, acaba desenvolvendo mecanismos compensatórios para contornar as situações embaraçosas e ofensivas criadas por ele mesmo. Nesse sentido, como diz o narrador, o que "salvava Amâncio era o bom coração, mas mesmo esse só se mostrava depois de um vexame grande: aí ele passava de demo a dama, não sabia o que fazer para agradar, dava presentes a torto e a direito, forçava as pessoas a comprarem fiado, perdoava dívidas, zangava-se com quem não aceitasse o perdão, tanto agrado até enjoava." ${ }^{40}$ Arbitrariedade, como se vê, até nos instantes em que tenta fazer-se agradável.

É este personagem, então, que se apresenta para fazer o contato com os estranhos, causando certo receio em seus conterrâneos, pois Amâncio, "Não tendo prática no manejo de palavras se embaraçava nas menores dificuldades e só achava saída no recurso à valentia" ${ }^{41}$. Apesar disso, os amigos nada podiam fazer na medida em que "quanto mais tentassem demovê-lo, mais encasquetado ele ficava" ${ }^{42}$. Sendo assim, apesar da preocupação de todos, Amâncio Mendes parte ao encontro dos forasteiros, não sem antes alguém observar discretamente se carregava algo na cintura.

É importante aqui a notação da dificuldade com o manejo de palavras em oposição ao recurso à valentia, além da presença, ou possível presença, de armas de fogo. O leitor da estória há de lembrar que no momento em que se torna ciente da ofensa de Amâncio, Geminiano se apodera de uma garrucha, prevenindo-se para qualquer afronta do comerciante, daí advindo, inclusive, a interferência do padre. Após

\footnotetext{
${ }^{39}$ Op. cit., p. 16.

${ }^{40}$ Op. cit., pp. 10-11.

${ }^{41}$ Op. cit., p. 16.

${ }^{42}$ Op. cit., p. 17.
} 
as palavras conciliadoras do religioso, ou o bom manejo das palavras, “(...) Geminiano sentiu a garrucha debaixo da camisa - grande e pesada como um machado, inútil, incomodando" ${ }^{43}$.

Percebem-se aí dois fatos: o primeiro deles diz respeito ao porte de armas que indica uma terra de homens bravos, afeitos a resolver as questões a bala, numa representação bastante veraz de um lugar cujo recurso à força, à violência, é um ingrediente comum, embora se perceba que esse traço ganha dimensões maiores em Amâncio Mendes graças à sua personalidade irascível. O outro fator, a falta do domínio da palavra, demonstra também mais uma característica do ambiente, a dificuldade de se obter um maior entendimento das coisas através do discurso, o que só é possível a partir da aproximação entre as partes envolvidas, aspecto que parece afetar a voz narrativa que se posiciona, como já foi dito, do ponto de vista da população, assimilando de certa maneira as limitações de comunicação que são próprias a esta.

Limitação que será evidente mais uma vez no momento em que Amâncio se prepara para a visita ao acampamento: o narrador acompanha o personagem descrevendo sua vestimenta especial, a passagem e o diálogo na casa do amigo Manuel Florêncio a fim de pedir que abrisse a mercearia em sua ausência, o dobrar de uma esquina já se distanciando e, de repente, “O chapéu branco de Amâncio desapareceu atrás do capim alto da beira da cerca, reapareceu mais adiante, tornou a sumir." 44

$\mathrm{Na}$ medida em que nenhum outro personagem circula próximo à cerca e o olhar do narrador não acompanha os passos de Amâncio, o grau de estranheza provocado pela distância permanece, agora agravado por uma expectativa crescente partilhada por todos que, enchendo a mercearia, aguardam o retorno do comerciante.

\footnotetext{
${ }^{43}$ Op. cit., p. 10.

${ }^{44}$ Op. cit., p. 18.
} 
No entanto, durante a visita, as informações que chegam são desconexas e inconsistentes: um garoto que passara próximo ao acampamento afirmara ter visto um grupo de homens entre os quais um todo de branco - Amâncio em sua melhor roupa jogando peteca. A notícia traz incômodo às conjecturas e opiniões da população que se aglomera em alguns lugares a espera de esclarecimentos.

Aliás, os aglomerados de gente em certos momentos da trama são um traço peculiar da narrativa. Sempre representados de uma maneira cômica, ansiosos por novidades para serem rapidamente transmitidas, se movendo em bloco do qual só são percebidas, na maioria das vezes, apenas exclamações aleatórias, perguntas, bravatas, xingamentos, esses personagens não têm rosto e se mostram incapazes de qualquer movimento de aproximação com os estranhos, ficando a mercê daqueles que conseguem esse contato.

Esse tipo de representação parece querer dizer de um certo caráter excludente do povo de Manarairema, na medida em que além de não poder ver nem chegar perto do acampamento, esse povo não é chamado a compartilhar as explicações sobre os estranhos. Configuração similar dessa distância do povo frente a algo tido como novo ocorre em outra narrativa do escritor, como bem salienta Iza Quelhas:

No conto $O$ galo impertinente, o povo de uma cidade do interior é apresentado como uma personagem colocada à margem da construção de uma estrada moderna, com técnicas e métodos inovadores e desconhecidos dos habitantes da localidade. O povo é personagem excluído, não pode ver nem chegar perto da obra que, apenas aparentemente, a ele se destina; ${ }^{45}$

Após seu retorno e para grande surpresa dos manarairenses, o vendeiro simplesmente cala sobre sua visita e foge de explicações a cada indagação mais objetiva

\footnotetext{
${ }^{45}$ QUELHAS, I. T. G. "No país do faz de contas: uma leitura da obra de José J. Veiga". In: Recorte - Revista de Linguagem, Cultura e Discurso, UNINCOR, Três Corações - MG, no 3, p. 5, 2005. O texto é uma condensação da dissertação de mestrado Hera, muros \& ruínas: a alegoria na obra de José J. Veiga. UFRJ, 1990.
} 
de seus conterrâneos. No silêncio ou na dissimulação fica, porém, certa sugestão de ações futuras e indeterminadas por parte dos estranhos sempre de caráter positivamente inovador e a cidade não tarda em perceber o efeito sedutor que a visita aos forasteiros causara em Amâncio.

Mesmo para o amigo Manuel Florêncio, que fizera o favor de cuidar da mercearia na sua ausência, Amâncio procura ocultar as ocorrências do seu encontro na tapera, embora somente a Manuel o comerciante forneça informações importantes para o enredo que parecem reforçar a contextualização histórica que se pretende como pano de fundo para a narrativa. O primeiro desses indícios ocorre quando Amâncio fica sabendo que fora visto brincando no acampamento dos forasteiros, ao que reage com certo deboche e desconversa:

- Quem sabe, sabe; quem não sabe indague, dizia meu tio Lindolfo. Ele foi padre, já contei? Padre assentado, cumpridor. Irmão de minha mãe. Um dia ele largou batina, largou rosário e foi ser revoltoso. Minha mãe quase morreu de paixão. Dizem que ele estanhou muita gente em combate. Foi anistiado. Creio que ainda vive, é professor de latim não sei onde. Eu tive um retrato dele que saiu num jornal. Fardado de oficial, com dois revólveres na cintura. Pelo tamanho das capas deviam ser parabelos. (...) Meu tio Lindolfo. Pe. Lindolfo, de parabelo na cintura. ${ }^{46}$ (Itálico meu)

Revoltoso era um qualificativo dado àqueles que aderiam à famosa Coluna Prestes/Miguel Costa, movimento que percorreu, em grande marcha, extenso território do interior brasileiro em meados dos anos 20 como uma manifestação oriunda do movimento tenentista de oposição ao governo federal. ${ }^{47} \mathrm{~A}$ fala do vendeiro auxilia para uma caracterização um pouco maior de sua ascendência familiar, da qual se destaca mais uma vez o pendor à valentia.

${ }^{46}$ VEIGA, J. J. Op. cit., p. 24.

${ }^{47}$ Cf.: SODRÉ, Nelson Werneck. A Coluna Prestes - análise e depoimentos. Rio de Janeiro, Civilização Brasileira, 1978, p. 11; SILVA, Hélio. 1926: A Grande Marcha (O Ciclo Vargas) Vol. II. Rio de Janeiro, Civilização Brasileira, 1965, p. 31; MEIRELLES, Domingos. As noites das grandes fogueiras. $2^{\mathrm{a}}$ edição, Rio de Janeiro, Record, 1995, p.72. 
Também é curioso reparar no que parece ser um aproveitamento estético de um dado empírico da passagem da Coluna Prestes por Goiás: além de se beneficiar, em algumas paradas, da simpatia de religiosos pelo movimento, a Coluna contou também na região com o alistamento factual em suas fileiras de uma figura religiosa, o padre Maneco Macedo, irmão de um futuro senador do estado, como esclarece o historiador goiano José Asmar:

Outro goiano na Coluna foi o padre Manoel Macedo, Maneco Macedo, que deixou a batina e moveu-se por ojeriza aos Caiado. Afastou-se da Marcha, viu-se preso e recambiado ao Rio. Prestes a ele dedica menosprezo. Tacha-o de tocador de violão e bêbado, que se embriagava, em Porto Nacional, com elixir de nogueira ao invés de cachaça. Padre Maneco era irmão do senador Nero Macedo, que deu nome ao município de Nerópolis, e que foi pai de Oyama Macedo, marido da acadêmica Rachel de Queiroz. ${ }^{48}$

O dado, embora não traga grandes significados à narrativa, parece indicar certa coerência na linha de raciocínio que se está tentando construir nessa presente leitura na medida em que parece bastante evidente o conhecimento histórico do escritor envolvendo personagens e lugares de sua terra e o seu aproveitamento para a composição desse momento da narrativa e para a caracterização mais abrangente do período histórico a que ele remete.

Outra fala de Amâncio que traz novo dado significativo para a configuração dos ambíguos forasteiros é a afirmação de que os homens não eram nada daquilo de ruim que os manarairenses pensavam, muito pelo contrário; segundo o comerciante, os estranhos eram um modelo a ser seguido pelo povo de Manarairema, principalmente porque não se tratava de um modelo local, acanhado e já conhecido por todos, mas sim de um modelo importado:

${ }^{48}$ Entrevista concedida ao Jornal Opção, Seção Especial, edição 1564, jun./jul., 2005, na qual o historiador revela alguns dados de seu livro Sangue nas águas verdes, que trata especificamente da passagem da Coluna Prestes por Goiás. O livro aguarda edição. 
- Se todo mundo aqui fosse como eles, Manarairema seria um pedaço de céu, ou uma nação estrangeira. ${ }^{49}$ (Grifo meu)

O significado dessa referência parece ser o mesmo da presença do casal de estrangeiros em A Usina atrás do morro ou da presença constante de gente desconhecida na cidade de Taitara (Sombra de reis barbudos) avaliando os riscos do empreendimento da Companhia e reunindo investidores dispostos a esses riscos. O que se vê em qualquer um desses dois casos é a presença de uma nova ordem, de pendor econômico, que vem alterar as relações interpessoais e a própria relação do homem com o seu meio. Em $A$ Usina atrás do morro, os moradores sentem a terra tremer durante a noite por causa do trabalho intenso das máquinas; em A hora dos ruminantes, Geminiano abre um buraco nas margens do rio de tanto carregar areia no seu trabalho semi-escravo, desfigurando a paisagem local; em $O$ galo impertinente, a natureza se revolta contra a derrubada de uma mata para a abertura de uma auto-estrada e cria um animal gigante, ironicamente metalizado que destrói a bicadas os carros que se arriscam a utilizar a rodovia, tornando-a uma estrada fantasma, destroço de um mundo futuro.

A diferença entre essas histórias parece se dar na configuração do ambiente a ser invadido, pois à exceção de Manarairema, todos os cenários das outras narrativas possuem caracteres essencialmente positivos na relação de antagonismo que estabelece com os elementos invasores, estes por sua vez carregados de aspectos negativos e intenções destruidoras em representações evidentes das oposições rural/urbano, campo/ cidade, locus amenus/locus horrendus. Nessas narrativas a dicotomia maniqueísta entre esses dois pólos parece bastante perceptível justamente pela ausência dos impasses, das contradições, dos conflitos internos inerentes aos locais invadidos, ainda pairando sobre eles certo ar idílico que, por sua vez, se não imprime exotismo no nível da configuração

\footnotetext{
${ }^{49}$ VEIGA, J. J. Op. cit., p. 25.
} 
do espaço local, graças à economia das descrições e o tom sóbrio do narrador, dá às relações pessoais e sociais dessas comunidades um aspecto exótico, por ser idealista, de uma fraternidade e harmonia totais.

Diferentemente desses lugares, o solo de Manarairema, como já dissemos, possui fissuras profundas por onde a água da chuva constrói caminhos peculiares e tortuosos aproveitando-se das brechas e dos leitos pré-existentes. Sem reparar no que está em seu caminho ela inunda todos os espaços e nivela uma confusão de coisas sob uma superfície de aparente calma. Da mesma maneira, as idéias, os costumes, os procedimentos dos forasteiros em Manarairema vão permeando as relações sociais da comunidade manarairense aproveitando-se das fraturas prévias dessa estrutura social. Nesse sentido talvez se possa dizer que $A$ hora dos ruminantes é a única narrativa, entre aquelas de Veiga que desenvolvem essa temática do conflito de culturas, que apresenta um ambiente problematizado e permeado de ambigüidades no nível dos relacionamentos pessoais e sociais, o que garante a ela lugar de destaque dentre as obras do escritor.

O comportamento obscuro e ambíguo dos forasteiros será reforçado a partir da visita de Amâncio na medida em que o comerciante sonegará aos manarairenses as informações que supostamente obtivera. Esse contato parece repetir também, agora figurativamente e em menores proporções, aquele mecanismo de cooptação de lideranças sugerido no caso da figura ausente do latifundiário Júlio Barbosa, o contato "pelo alto". Isso porque é evidente certa preeminência do personagem de Amâncio na comunidade manarairense, fato constatável não só na caracterização minuciosa que é feita de sua personalidade, mas também no papel de destaque que possui o ambiente da mercearia no enredo, ambiente que será também o centro de irradiação da influência dos 
estranhos na medida em que, estabelecido o primeiro contato por parte do vendeiro, a mercearia será uma área livre para os estranhos em Manarairema.

A cidade não tarda a perceber que Amâncio se tornara uma espécie de "advogados dos homens", embora em nenhum momento ele evidencie o motivo concreto dessa empatia. Ou seja, o comerciante ostenta um conhecimento que em nenhum momento se materializa, parecendo querer manipular certo tráfico de influência através de um jogo de aparências que lhe permite a manutenção de sua posição social de destaque à custa de uma clara posição de subserviência e sujeição aos estranhos.

Ao final do capítulo verifica-se o seguinte estado de coisas: apesar de perceberem a influência malévola dos estranhos sobre a cidade, a população parece se adequar rapidamente à situação geral, repetindo um certo esquema de ESPANTO $\rightarrow$ CURIOSIDADE $\rightarrow$ CONFORMISMO. Primeiro, acostumara-se com a presença muda e incômoda do acampamento no outro lado do rio, depois aceitara quase passivamente a perda do serviço de Geminiano, e por fim não exigira um esclarecimento de Amâncio sobre sua postura controversa, postura, aliás, que acaba viabilizando a interferência cada vez mais direta dos estranhos na cidade, pois a mercearia se torna local livre para eles exercerem sua autoridade arbitrária, até mesmo exigindo a saída do povo nos momentos de visita ao comerciante.

Das intenções dos homens, de sua ocupação verdadeira a cidade continuava na mesma ignorância do primeiro dia. Se Amâncio sabia alguma coisa, guardava bem o segredo (...) desconversava troçando ou saía com o perguntador na testa. Amâncio estava ficando tão antipático como os seus amigos da tapera. ${ }^{50}$

\footnotetext{
${ }^{50}$ Op. cit., p. 31.
} 


\subsection{Cooptação e resistência: do provável ao possível}

O segundo capítulo da narrativa inicia diretamente com a invasão dos cães, ou como diz o narrador com mais propriedade, "o derrame dos cachorros". O fato é que esses animais já eram percebidos pela população há algum tempo graças ao grande alarido que faziam no acampamento, uma intensa latomia que parecia, aos mais atentos, aumentar gradativamente a cada dia, já incomodando não poucas pessoas. Indagado sobre a presença dos bichos, Geminiano uma vez mais não consegue ser objetivo nas suas explicações que sugerem uma quantidade enorme de animais, talvez centenas, o que é interpretado como mais um efeito da confusão mental pela qual passa o carroceiro.

No entanto, a informação de Geminiano se mostra verdadeira e a ocupação se dá de repente: os cães invadem galinheiros, ocupam quintais e jardins, ruas e praças, enquanto os habitantes se fecham nas casas sem compreender aquela inversão da ordem. Alguns cachorros encontram brechas pelas quais invadem desafortunadas residências, maculando quartos, defecando nas salas, arrancando e arrastando lençóis e toalhas, deixando os moradores paralisados de susto.

Munindo-se de armas de fogo e outras tantas improvisadas, alguns manarairenses procuram se precaver contra possíveis ataques dos bichos, o que não ocorre devido à surpreendente ausência de ferocidade dos animais. Com o passar do dia se constata que os bichos estão mais interessados em "dar vazão à energia represada na disciplina da tapera", o que fez com que as pessoas criassem coragem para sair desarmadas de casa, "uns até já achavam graça nos desatinos e bodejos dos bichos." 51

\footnotetext{
${ }^{51}$ Op. cit., p. 37.
} 
Aos poucos a população parece aceitar esse contexto de exceção não como algo normal, talvez, mas pelo menos como algo assimilável, tal a carestia e as privações da vida, ao qual se tenta imprimir a naturalidade cotidiana da vida no lugar, por mais inconvenientes e esdrúxulas que fossem as situações criadas pelos cães. Mais ainda: os manarairenses não só parecem se acostumar com os cachorros, como também começam a praticar atitudes de servilismo aos animais:

(...) De repente ficou parecendo que todo mundo adorava cachorro, quanto mais melhor, e só tinha na vida a preocupação de fazê-los felizes (...).

Muita almôndega macia, fritada em boa gordura, lhes foi servida em prato de louça, como se faz com hóspedes de categoria. Toda a cidade estava praticamente a serviço dos cachorros, tudo o mais parou, ficou adiado, relegado, esquecido. Qualquer cachorro pelado, sujo, sarnento, contanto que fosse estranho, encontrava quem o elogiasse por qualidades que ninguém via mas que todos confirmavam. Era uma grande vantagem ser cachorro estranho em Manarairema naqueles dias. (...) Foi um tempo difícil aquele para os puros, os ingênuos, os de boa memória. ${ }^{52}$

A ironia que surge do tom e da forma solenes da última frase, tratando de uma situação ridícula porque degradante, expõe a consciência crítica do narrador no que concerne à aceitação pelos manarairenses da nova ordem que se impõe. Para demonstrar essa mudança de mentalidade da população a voz narrativa recorre ao exemplo: o filho que é castigado pelo pai por ameaçar um dos cachorros com o chicote que o próprio pai havia, anteriormente, preparado para esse mesmo fim (tempo dificil aquele para os puros). Ou pela diversão de alguns moradores em assistir e até ajudar os cachorros na perseguição às galinhas: quando uma delas consegue se refugiar, acaba sendo retirada do esconderijo pelo próprio dono e oferecida aos cachorros visitantes que recusam a coisa ofertada. Ou ainda no comportamento servil dos moradores para com as

\footnotetext{
${ }^{52}$ Op. cit., pp. 36-37.
} 
necessidades básicas dos cães que são tratados com todas as regalias possíveis (muita almôndega macia).

São escassas as indicações de quanto tempo os cachorros conviveram com a população; no entanto, foi tempo suficiente para que os moradores se acostumassem, na maioria das vezes aderindo, a esse novo estado de submissão. Mas essa presença canina não dura muito tempo e ao fim de certa tarde os cachorros "dispararam no rumo da tapera". Da mesma maneira que chegaram, eles se foram: atabalhoadamente, derrubando ou sendo derrubados pelos outros cães ou por qualquer coisa que estivesse no caminho, saindo de todos os lugares como obedecendo a um comando inaudível para humanos. As pessoas em Manarairema não atinam com o ocorrido, a perplexidade parece mais uma vez estampada no rosto de cada morador, "As pessoas ficaram sem saber o que fazer, com medo de se descontraírem antes da hora e terem de repor a máscara às pressas." 53

Mesmo depois de constatar a partida dos cães os manarairenses não demonstram nenhum tipo de satisfação ou alegria pela ausência dos bichos, mas sim a vergonha de ter tão prontamente aceitado o que se tinha imposto de maneira abrupta, estranha e constrangedora. Aliás, constrangimento é a nota dominante entre os habitantes da cidade, tanto entre os que aderiram àquele estado de exceção quanto entre os que o desaprovaram em silêncio que "é pouco menos do que aprovar".

Apesar da marcas deixadas pelos cachorros, a cidade retoma sua rotina se esforçando para esquecer a situação vexatória que vivenciara, e mais uma vez a mercearia de Amâncio será o palco para as tensões que vão aos poucos se avolumando na narrativa. Como vimos, o primeiro capítulo do livro encerrara-se com o início das visitas que se tornariam contínuas por parte dos estranhos à mercearia (perceber que a recíproca não é verdadeira, ou seja, Amâncio só teve acesso à tapera um única vez 
enquanto os estranhos se farão constantes no espaço da venda), interrompidas com a chegada dos cães. Agora, provavelmente influenciado por essas visitas, a intenção declarada do vendeiro é fazer algumas reformas no estabelecimento com vistas a ampliar o comércio, evitando nas suas elucubrações qualquer referência ao derrame de animais. Porém, como não poderia deixar de ser, após o sentimento de humilhação experimentado por quase toda a gente manarairense, surgem as primeiras vozes de protesto quanto à atitude dos homens de soltarem os bichos sobre os moradores. Para os reclamantes tal comportamento hostil, desrespeitoso e ilógico pressagiava as intenções daqueles forasteiros. Dentre as personagens que questionarão o propagandeado benefício dos estranhos encontra-se Manuel Florêncio, o marceneiro da cidade, cuja presença já se fizera notar no primeiro capítulo de maneira tímida e coadjuvante e que a partir de agora vai ganhar importância e significado capitais no desenvolvimento do enredo.

Manuel tem papel de destaque porque é o único personagem cujas opiniões e intervenções denotam uma constante preocupação com o aspecto propriamente comunitário da coletividade manarairense, além de ser homem comedido e de bom trato, amigo de todos, sempre pronto para eliminar aparas de qualquer diálogo ou situação mais áspera. As diferenças entre Manuel e Amâncio, que já ficam evidentes na caracterização sumária que o narrador faz de cada personagem, ganham maior consistência quando são estabelecidas na prática, nas ações de cada um deles defronte os problemas individuais dos moradores e os impasses da comunidade para com a hostilidade dos forasteiros.

A disposição em ajudar os outros e o desprendimento de Manuel em deixar seus afazeres para esses auxílios é uma constante no caráter desse personagem que parece ter sempre uma preocupação primeira com a ordem coletiva. As atitudes de Manuel, 
portanto, são sempre fraternas, amigáveis, altruístas, como reforçam as cenas com a anciã e com a criança na mercearia. Ao mesmo tempo Manuel é pessoa que mostra seu desagrado na hora, sem cultivar ofensas, mas dizendo, quando necessário, verdades pouco apreciáveis aos seus ouvintes. Esse comportamento reto numa sociedade com as fissuras existentes em Manarairema, é também motivo de comentários maldosos “Quem ele pensava que era? Secretário de Deus? Fiscal do mundo?" 54

Mas, em contraponto às vozes que o criticam existem aquelas que afirmam proverbialmente que Manuel era "amigo, sempre, em qualquer repuxo", e que se "pisava em algum rabo de vez em quando era porque havia muito rabo espalhado, [e] a culpa era mais dos rabudos" ${ }^{55}$. Essa característica do marceneiro Manuel já ganhara seus contornos no primeiro capítulo quando o narrador, ao compor a personalidade individualista e arbitrária de Amâncio Mendes, estabelecera paralelamente a fraternidade amiga e inabalável de Manuel Florêncio, num movimento de aproximação e distância devido à acentuada diferença entre eles ao mesmo tempo em que estão envolvidos por laços de amizade.

O narrador afirmara ainda que ao comerciante incomodava aquela postura comedida e conciliadora de Manuel, "aquela mania de ser palmatória do mundo, de dizer coisas que ninguém gosta de ouvir". No entanto, ao fim das contas, "Amâncio tinha de reconhecer que ele [Manuel] sabia pensar e agir certo." 56 O próprio comerciante, ao voltar da visita, irrita-se com o amigo que não aceita um agrado pelo trabalho de ter cuidado da venda, e mesmo quando Manuel parece aceitar, simplesmente para não provocar o temperamento irascível de Amâncio, acaba por esquecer o embrulho, causando uma ação violenta, embora solitária, por parte do comerciante.

\footnotetext{
${ }^{54}$ Op. cit., p. 25.

${ }^{55}$ Op. cit., p. 26.

${ }^{56}$ Op. cit., p. 25.
} 
Idêntico sentimento de amizade e solidariedade transparece nas palavras, postura e reflexões de Manuel no diálogo com o ferreiro Apolinário a quem procura a fim de encomendar determinado serviço: sabendo do momento de pressão pelo qual passa o ferreiro, Manuel é sensível na escolha das palavras e do tom do diálogo, cuidando em evitar subentendidos ou pressupostos embaraçosos. Até na difícil conversação que estabelece com Geminiano, num momento tenso e de fundamental importância na narrativa, Manuel se mantém cordial e compreensivo, embora firme na sua decisão contrária à do seu interlocutor.

Todas essas atitudes do carpinteiro vão gradativamente garantido a constituição de uma personalidade de elevada moral a quem o narrador se refere numa tonalidade afetiva de aproximação. Talvez se possa dizer que Manuel Florêncio atinge o ponto mais elevado dentre todos os personagens de $A$ hora dos ruminantes, encarnando uma figura que Walter Benjamin destacara em seu famoso estudo sobre narração, a figura do Justo, aquele que materializa "a sabedoria, a bondade, o consolo do mundo": "O Justo é o defensor da criatura e, simultaneamente, sua encarnação mais alta" ${ }^{57}$. Neste carpinteiro do interior do país, o aspecto fraterno, filantrópico, paternal, "Aquela mania de ser honesto, de ser a palmatória do mundo" ${ }^{58}$, se intensifica até o limite, como no exemplo de seu comportamento abnegado de resgatar o embriagado Amâncio, "caído em alguma grota, machucado e enlameado depois de uma noite de cachaçada e desatino" ou de se condoer com a fragilidade física e econômica da idosa que entra na mercearia para comprar fumo, "Uma velhinha pretinha, encolhidinha, trêmula no falar e no estar" 59 .

\footnotetext{
${ }^{57}$ BENJAMIN, Walter e outros. "O narrador: observações sobre a obra de Nikolai Leskow”. In Textos escolhidos. Trad. Modesto Carone. $2^{\mathrm{a}}$ ed., São Paulo, Abril Cultural, 1983, p. 71.

${ }^{58}$ VEIGA, José J. Op. cit., p. 25

${ }^{59}$ Op. cit., p. 19.
} 
Manuel era mestre em muitas coisas que uma pessoa deve saber para poder viver neste mundo difícil. Manuel Osório de Almeida Florêncio. Manuel bobo. Manuel ladino. Manuel amigo. ${ }^{60}$

É esta figura íntegra que levanta a voz para questionar os benefícios hipotéticos que os estranhos estão para trazer a Manarairema: pontual, lógico e transparente, Manuel se propõe a escutar, na frente de vários moradores reunidos na venda, as explicações de Amâncio que justifiquem e que conciliem as proclamadas boas intenções futuras dos estranhos defendidas pelo comerciante, com a atitude despropositada e ultrajante da soltura dos cachorros sobre a cidade.

Como a relação de amizade estabelece um nivelamento na posição e na importância dos dois personagens, o arbítrio de Amâncio, parcialmente responsável pelo seu lugar na estrutura social de Manarairema, encontra agora um oponente à altura, ou seja, a reflexão cartesiana de Manuel Florêncio, também este detentor de alguma autoridade entre os manarairenses, que parece não aceitar facilmente os subterfúgios do amigo comerciante.

Questionado de maneira incisiva e direta, o vendeiro não consegue dizer nem explicar objetivamente ao compadre e aos outros moradores, quais melhorias seriam feitas pelos estranhos na cidade. Vexado pela impossibilidade de justificar suas palavras o comerciante se esforçará por embaralhar cada vez mais a conversa a fim de se vê livre de minudências comprometedoras daquilo que sabe ou que demonstra saber. Na medida em que não consegue argumentar uma explicação que harmonize as intenções e as ações dos estranhos, Amâncio logo perde a compostura durante o diálogo (a dificuldade com a palavra) e de maneira gratuita culpa Geminiano Dias (!) pela confusão de juízos explicitados ali na conversa, ativando mais uma vez seu enraizado preconceito através

\footnotetext{
${ }^{60}$ Op. cit., p. 41.
} 
de palavras e imagens virulentas, "O culpado é Geminiano. Ele vai ver comigo. Pretete fedido." 61

Demonstrando novamente seu caráter voluntarioso e arbitrário, Amâncio suspende a conversação com os conterrâneos reforçando sua adesão parcial, sem questionamento, aos estranhos. A crescente animosidade de Amâncio também faz Manuel recolher suas indagações para evitar maiores atritos entre os dois, reiterando comportamento peculiar, "mestre em evitar briga sem correr" ${ }^{62}$, se mantendo numa atitude de espera e ressalvando ainda uma vez mais sua crença no amigo Amâncio, embora este continue inalteravelmente enigmático e arisco.

De qualquer maneira o voto de confiança anima o vendeiro que demonstra seu otimismo e sua alegria através da oferta de uma rodada de bebida aos presentes. Porém, furtando-se ao brinde, Manuel pretende deixar claro sua discordância quanto àquele clima de euforia que Amâncio quer denotar. Desconfiado, prefere retornar à oficina, ao seu trabalho e aguardar um pouco mais os acontecimentos, sem saber que não seria necessário esperar muito tempo.

Isso porque ao chegar a sua casa, Manuel encontra Geminiano Dias à espera para aquela que será a primeira cena entre os dois personagens. A razão dessa presença é simples e prosaica: a roda da carroça quebrara devido ao desgaste natural provocado pelo utilização incessante, sem tempo para reparos de manutenção. Interessante perceber aqui que até a coisa (a carroça) possui um momento para recuperação do uso contínuo, enquanto que o ser já envolvido física e mentalmente no processo de coisificação rechaça a possibilidade desse momento de revigoramento, como ocorre literalmente na cena do primeiro capítulo em que Geminiano sofre um abalo emocional

\footnotetext{
${ }^{61}$ Op. cit., p. 40.

${ }^{62}$ Op. cit., p. 41.
} 
e psíquico no instante em que a carroça já desconjuntada pelo volume carregado derrama areia no chão.

O contato e a fala do marceneiro são naturalmente cordiais, porém, o comportamento de Geminiano, alterado pelo alheamento próprio do seu servir aos estranhos e pela ascendência deles sobre si, já não entra em sintonia com essa cordialidade de Manuel. Movendo-se de um extremo ao outro, ou seja, de uma atitude de explícito servilismo ("pediu licença para cumprimentá-lo de perto" ${ }^{63}$ ) a uma tonalidade autoritária na fala ("Está vendo essas tábuas velhas? O senhor vai me mudar todas elas." ${ }^{64}$ ) Geminiano já demonstra sua inadequação aos preceitos e costumes de convivência da cidade, dedução a que rapidamente chega Manuel identificando nesse comportamento a influência do convívio do carroceiro com os forasteiros da tapera.

O marceneiro incomodado com o tom autoritário da última fala de seu interlocutor e ciente, ao longo do diálogo, de que a carroça não mais pertence a Geminiano e sim aos forasteiros, nega categoricamente qualquer possibilidade de suspender sua rotina para atendê-lo. A partir daí a cena será uma disputa verbal entre os dois personagens, Geminiano desfilando um rosário de motivos para Manuel aceitar o trabalho imposto, e Manuel, por seu lado, rechaçando todos eles numa irritação crescente devido à insistência do carroceiro.

Talvez não seja inadequada aqui a lembrança do que diz Sérgio Buarque de Holanda sobre a peculiar noção de trabalho na tradição ibérica em contrapartida à visão protestante ( $O$ trabalho manual e mecânico, inimigo da personalidade):

Efetivamente, as teorias negadoras do livre arbítrio foram sempre encaradas com desconfiança e antipatia pelos espanhóis e portugueses. Nunca eles se sentiram muito à vontade em um mundo onde o mérito e a responsabilidade individuais não encontrassem pleno reconhecimento. (...)

\footnotetext{
${ }^{63}$ Op. cit., p. 41.
}

${ }^{64}$ Op. cit., p. 42. 
A ação sobre as coisas, sobre o universo material, implica submissão a um objeto exterior, aceitação de uma lei estranha ao indivíduo. (...) $\mathrm{O}$ trabalho manual e mecânico visa a um fim exterior ao homem e pretende conseguir a perfeição de uma obra distinta dele. ${ }^{65}$

A mesma linha de reflexão o autor desenvolve nas suas notas sobre o romance:

Em realidade o trabalho serve para ancorar os homens, para acomodá-los a exigências da vida circunstante, nunca, porém, a exigências espirituais. Ele não tem por si só nenhuma função ordenadora, por conseguinte não se pode esperar que oriente e sublime decisivamente a vida humana. E sua exaltação há de corresponder por força a certa depreciação das atividades do espírito e da alma, precisamente das atividades que distinguem, discriminam e subordinam, como o conhecimento ou o amor. ${ }^{66}$

Resguardado pela possibilidade de negar o serviço a partir de uma decisão pessoal, Manuel justifica a impossibilidade argumentando ter excesso de trabalho, motivo que não denota ser verdadeiro, pois não se vê, ao longo da narrativa, Manuel Florêncio desenvolvendo sua atividade de marceneiro efetivamente.

O leitor também percebe sem muita dificuldade a alteração ocorrida em Geminiano Dias, pois se no início da narração o carroceiro aparece como alguém de trato fácil, respeitador dos direitos alheios, cordial, obediente, nesse momento seu comportamento se aproxima ao procedimento pouco simpático dos forasteiros, impositivo, intransigente e ameaçador (“- Seu Manuel, pense bem no que está fazendo para não se arrepender mais tarde.” ${ }^{67}$ ). Na mesma medida em que cresce a insistência de Geminiano, cresce também a resistência de Manuel num momento da narração em que predomina o modo dramático, recurso que parece imprimir maior tensão à cena por

\footnotetext{
${ }^{65}$ HOLANDA, Sérgio B. Raízes do Brasil. $7^{\mathrm{a}}$ ed., Rio de Janeiro, José Olympio, 1973, pp. 9-10. Cobra de vidro. $2^{\mathrm{a}}$ ed., São Paulo, Perspectiva, p. 60.

${ }^{67}$ VEIGA, J. J. Op. cit., p. 43.
} 
aproximar ao máximo o leitor do momento dos acontecimentos com um mínimo de mediação do narrador.

Após a recusa definitiva e enfática de Manuel, Geminiano recolhe-se vagaroso e desnorteado compondo uma imagem que provoca profunda sensação de melancolia no marceneiro, além da reflexão dolorosa sobre o estado em que se encontra Geminiano e a própria cidade de Manarairema, num momento de forte lirismo na narrativa. Consciência crítica da coletividade, Manuel Florêncio contempla já saudoso um Geminiano que é somente sombra daquele que existira. Paralelamente, o largo da cidade, tão familiar e tão íntimo, aparece agora tal como um lugar estranho, avesso à vida, tocado irremediavelmente pelas transformações que se anunciam:

(...) Manuel pensou no Geminiano antigo, tão senhor de si, correto, respeitador dos direitos alheios. Que força teria conseguido transformar aquele homem inteiriço nesse inútil feixe de medos? Olhando para cima, para baixo, para as casas em frente, Manuel sentiu que não estava vendo o largo familiar, mas um trecho de outra cidade, remota, inóspita, maligna. Manarairema estaria se acabando, se perdendo para sempre? Se estava, valeria a pena continuar vivendo ali? Não seria melhor vender a casa, juntar as ferramentas num caixote e sair estrada afora, trabalhando de fazenda em fazenda nos serviços que aparecessem? ${ }^{68}$ (p.44)

Reparando muito além da situação que ali acabara de se desenrolar, o olhar perspicaz de Manuel identifica no desatino do carroceiro a própria desestruturação e o desnorteamento que ameaça a cidade de Manarairema, projetando para ela e para si, de maneira totalmente desiludida e cética, a ruína e a desagregação, visto que seu o próprio futuro se encaminha para um provável trabalho marginalizado e nômade em face da nova ordem que se impõe. Ao visualizar sobre si os reflexos dessa força que ele já identifica tão prontamente em Geminiano, Manuel parece pressentir a inexorabilidade da situação que se impõe numa vidência baseada na sua capacidade de articular algum ${ }^{68}$ Op. cit., p. 44. 
sentido entre os fatos, costurando-os com a linha da experiência e do esforço que o levem a uma clareza de idéias.

A negativa de Manuel irá rapidamente chegar aos ouvidos de Amâncio Mendes através de um dos forasteiros com o qual Amâncio se mostra mais servil, referindo-se a ele como major e demonstrando uma deferência excessiva no trato, o que indica uma posição hierárquica de destaque por parte do estranho. $\mathrm{O}$ tal homem procura Amâncio para reclamar da conduta do marceneiro no tocante ao conserto da carroça, num diálogo não explicitado devido à distância do foco narrativo, mas cujo conteúdo se deduz pelo fato de se encaminharem à casa de Manuel, os dois discutindo e gesticulando muito. Amâncio impede que o estranho entre na residência do marceneiro numa atitude menos de discórdia que de contemporização. Como já se disse, porém, toda essa cena é apenas dedutível em função da distância da voz narrativa.

Dispensado o estranho, Amâncio e Manuel se encontrarão num diálogo que é um dos momentos mais felizes da trama. Colocados frente a frente, num ambiente privado e não público como o da mercearia, evitando olhares indiscretos e embaraçosos, os dois personagens travarão uma acirrada e áspera conversa com a explicitação das diferenças de cada um frente aos forasteiros e o questionamento das atitudes ambíguas do comerciante. Num primeiro momento, Amâncio se comporta em conformidade com sua índole voluntariosa e autoritária tentando se impor com a força e o tom de suas palavras ferinas, ao que é retrucado de maneira firme por Manuel, com a lembrança de que o vendeiro está em casa alheia, apesar de amiga, e que, portanto, a conversa deve se dar numa outra tonalidade. Como a intenção de Amâncio é persuadir o amigo, logo percebe que o embate não é a melhor estratégia, como havia sido no caso de Geminiano Dias.

O argumento do comerciante para sensibilizar o marceneiro deixa, então, de ser o do confronto de opiniões para transformar-se num apelo emocional que invade a 
esfera privada com a manifestação de um traço comum e permanente na cultura do país, a relação de favor, que surge em mais um contexto peculiar para disfarçar ou encobrir as verdadeiras tensões existentes nos interesses díspares dos tipos manarairenses:

Amâncio experimentou nova tática:

- Somos amigos de muito tempo, Manuel...

- Somos. E o que é que tem isso? Você por acaso...

- Deixe eu falar. Somos amigos de muito tempo. Eu vim aqui pedir um favor. Conserte a carroça para mim. ${ }^{69}$

Aqui, como se percebe, é bastante adequada a afirmação de Roberto Schwarz:

O favor é nossa mediação universal - e sendo mais simpático do que o nexo escravista, a outra relação que a colônia nos legara, é compreensível que os escritores tenham baseado nele a sua interpretação do Brasil, involuntariamente disfarçando a violência, que sempre reinou na esfera da produção. ${ }^{70}$

Num primeiro instante a atitude de Manuel permanece refratária ao pedido de Amâncio, mas aos poucos o carpinteiro se ressente da tonalidade amigável da fala de seu interlocutor, pois, como se viu, Manuel é um personagem de bom trato, sempre disposto à concórdia e ao equilíbrio das opiniões para o bem comum; a nova tática de Amâncio, assim, visa justamente tocar a sensibilidade do marceneiro através dessa sua característica específica e para isso o comerciante resgata através de lembranças um tempo que agora só vive na memória de ambos. A mesma contemplação do largo da cidade, ocorrida instantes antes com Manuel Florêncio, se repete agora com Amâncio Mendes como a demonstrar uma similaridade de sentimentos a unir os dois amigos distanciados pela posição de cada um frente aos estranhos e à nova realidade:

\footnotetext{
${ }^{69}$ Op. cit., p. 46.

${ }^{70}$ SCHWARZ, Roberto. “As idéias fora de lugar”. In Cultura e política. $2^{\mathrm{a}}$ ed., São Paulo, Paz e Terra, 2005, pp. 65-66
} 
Amâncio parou de falar, chegou à janela, olhou o largo com interesse, como quem se despede de um lugar antes de uma viagem demorada, com o cavalo arreado e o arrependimento de ir já doendo por dentro; e continuou falando para fora, indiferente à presença de Manuel Florêncio:

- Quem havia de dizer que Manarairema ia mudar em tão pouco tempo... Antigamente a gente vivia descansado, sossegado, dormia e acordava e achava tudo no lugar certo, não era preciso pensar em nada adiantado (...) O que foi que nós fizemos para acontecer isso?

Manuel olhou-o meio comovido, meio desconfiado. Aquele lado novo não esconderia alguma armadilha? ${ }^{71}$

A tonalidade afetiva do discurso de Amâncio surpreende Manuel Florêncio e o próprio leitor. Ainda assim a fala do vendeiro, em intervenções mais sugestivas do que explicativas, não é capaz de responder objetivamente às questões elaboradas pelo carpinteiro, motivo que faz crescer a curiosidade e expectativa sobre o que há de tão ameaçador nos forasteiros, capaz de alterar todo um modo de vida de maneira tão abrupta e totalizante. Quais são, enfim, as novidades tão terríveis que existem naquele acampamento?

Embora não queira, ou não consiga, verbalizar de maneira efetiva os motivos que o fazem agir daquela maneira, Amâncio Mendes demonstra estar ciente do papel que cumpre na medida em que propaga para toda cidade uma imagem positiva dos estranhos e agora, para persuadir Manuel, anuncia o que parece ser a verdadeira face de uma novidade que não é somente positiva ou que não é tão positiva assim:

- Precisamos ficar muito unidos, compadre. Vamos atravessar uma quadra de grande dificuldade (...). Não pensei que chegasse a esse ponto, mas chegou. Caímos na ratoeira e por enquanto não vejo saída (...) Quem me dera que fosse tudo brincadeira, (...) Mas eu estive lá. Antes não tivesse estado. $^{72}$

\footnotetext{
${ }^{71}$ VEIGA, J. J. Op. cit., p. 47.

${ }^{72}$ Op. cit., p. 47.
} 
Depois dessa fala de Amâncio o silêncio impõe-se entre os dois amigos e o leitor pressente o fim da discussão ainda em dúvida sobre a resposta do marceneiro. Nesse momento crítico, em que o silêncio pesa sobre o peito de Manuel acarretando para a voz narrativa, sintomaticamente, uma dificuldade maior de expressão, o olhar do narrador se volta para a quietude do largo da cidade que parece harmonizar-se com o silêncio do próprio Manuel, numa configuração em que se percebe de maneira evidente a profunda ligação entre o marceneiro e o lugar (“O silêncio do largo lembrava a tranqüilidade antiga mas vinha misturado com uma espécie de cheiro de perigo iminente." ${ }^{73}$ ). De repente, na ausência melancólica de palavras, surge a imagem que surpreende e parece sintetizar o que não se consegue articular através do discurso.

Uma borboleta grande azul-pomposa entrou tonta na oficina, esbarrou de raspão na parede, pousou no cabo de uma enxó. Os dois olharam para ela encantados, como se nunca tivessem visto uma borboleta igual, ou talvez estranhando que ainda pudesse haver borboleta no ar. Finalmente, ela se despregou da enxó, tateou pela sala e escapuliu para o largo como chupada pelo ar da tarde, e eles ficaram mais tristes e preocupados. ${ }^{74}$

Imediatamente após essa cena ocorre a resposta de Manuel. Constrangido e demonstrando ainda contrariedade, o marceneiro, chamado à realidade pelo vento da tarde tal qual a borboleta, aceita fazer o conserto da carroça.

A reação de Amâncio à resposta do amigo é abraçá-lo demoradamente em agradecimento. Pouco acostumado ao gesto, o vendeiro "apenas engrolou algumas palavras que não chegaram a ser entendidas." ${ }^{75}$ Encerra-se assim, o caso do conserto da carroça, com a anuência de Manuel e a sensação de que os estranhos obtiveram uma

\footnotetext{
${ }^{73}$ Op. cit., p. 48.

${ }^{74}$ Op. cit., p. 48.

75 Op. cit., p. 48.
} 
vitória considerável ao conseguir dobrar aquele que parecia ser o mais consistente opositor aos modos e desmandos que eles tentavam impingir à população.

A decisão do marceneiro causa um profundo sentimento de pesar no leitor na medida em que Manuel era sem dúvida o personagem de maior empatia por encarnar princípios que pareciam ser comuns a ambos. No entanto, é necessário perceber que ao fazer o personagem assumir as contradições estruturais do ambiente o narrador expõe a forma possível de existência desses princípios, ou seja, de maneira contraditória. Sem desmenti-los, a narrativa exige a paga em troca dessa possibilidade de existência: a convivência desses princípios numa situação empírica que, paradoxalmente, nega-os.

Isso porque, se no caso de Geminiano há um aproveitamento de certo nexo escravista enraizado e reforçado por um silencioso senso comum entre os manarairenses, agora o que se vê é um aproveitamento de um mecanismo insidioso que permeia até inconscientemente as relações do lugar como algo natural, o favor. A adesão dessa prática por Manuel Florêncio parece embaralhar todas as idéias positivas que se tinha a seu respeito. Segundo Schwarz,

O elemento de arbítrio, o jogo fluido de estima e auto-estima a que o favor submete o interesse material não podem ser integralmente racionalizados. [...] $\mathrm{O}$ favor, ponto por ponto, pratica a dependência da pessoa, a exceção à regra, a cultura interessada, remuneração e serviços pessoais. ${ }^{76}$

Portanto, o favor desorganiza até mesmo as idéias que o leitor fazia do personagem, assim como os princípios de bem-estar coletivo acabam por sofrer um duro golpe através da prática que privilegia o particular. E, parafraseando Schwarz, o favor é tão incompatível com as idéias de solidariedade e igualdade de Manuel Florêncio quanto o nexo escravista imposto explicitamente a Geminiano Dias e implicitamente a

\footnotetext{
${ }^{76}$ SCHWARZ, Roberto. Op. cit., p. 66.
} 
toda população. Porém, mais insidiosamente que essa lógica escravista, o favor absorve e desloca os princípios originando um padrão particular de interesses e intenções.

O comportamento do personagem no restante do enredo, mais especificamente no seu encontro com o ferreiro Apolinário demonstrará sua consciência trincada sobre as conseqüências da atitude ambígua que acabara de tomar. O recorte imediato da cena por parte do narrador oculta o desenvolvimento da ação de Manuel e o leitor não toma conhecimento do conserto propriamente dito.

O narrador mais uma vez desvia seu olhar de maneira objetiva para outro momento da narrativa e a mudança de foco recai para a presença cada vez mais constante dos estranhos pelas ruas e pelo largo de Manarairema, trazidos diariamente por Geminiano nas suas idas e vindas intermináveis. A presença desses forasteiros na cidade traz contrariedades aos moradores devido ao já referido comportamento agressivo e arrogante que acaba fazendo das crianças, segundo o narrador, as vítimas preferidas por causa mesmo de sua condição física mais frágil.

Entre essas crianças destaca-se Mandovi, única personagem infantil nomeada na história, garoto de 12 ou 13 anos, filho de Apolinário, o ferreiro, e de D. Serena. O garoto ajuda os pais vendendo os cigarros que a mãe prepara manualmente em casa, agrupando-os enrodilhados em pequenos feixes e acondicionando-os numa caixa. Certa tarde, o menino é importunado por dois dos forasteiros que, curiosos sobre a maneira de se preparar os maços de cigarro, causam a destruição de um deles, além de esparramarem as demais rodilhas pela rua sem arcar com os danos ao produto. $\mathrm{O}$ garoto, revoltado com a truculência dos estranhos e com o prejuízo que teria de ser explicado aos pais, "apanhou umas coisas no chão, pedras, paus, sabugos, e foi jogando a esmo, 
com raiva, os baques fofos, os gritos, os homens correndo, as pedras não alcançando mais." 77

Ao retornar para casa e antes que pudesse explicar qualquer coisa, o menino é surpreendido por uma quantidade pouco comum de visitas em sua residência: todos já sabiam do ocorrido e já o haviam transmitido a seus pais. A expectativa dos visitantes era de que o ferreiro fosse castigar o garoto, e eles estavam ali justamente para presenciar o castigo, ou, pelo menos escutar o choro do menino. Isso não ocorre, todavia. Apolinário, após escutar o depoimento do filho, acha justa sua atitude e não o castiga.

Dispensada a multidão, D. Serena expressa ao marido o temor de que os forasteiros, ao saberem que o garoto não havia sido castigado, achem algum meio de atingi-los. $\mathrm{O}$ ferreiro dilui o temor da mulher em algumas bravatas sobre a reação dele no caso de alguma atitude dos estranhos, o que acaba por aumentar a tensão de D. Serena. Apesar dos temores o tempo passa sem que nada referente ao caso ocorra. A rotina anterior ao episódio retorna e Mandovi pôde, inclusive, voltar à sua atividade de vender os cigarros.

Sobre a família de Apolinário é necessário que façamos duas notações. A primeira delas diz respeito às presenças, até então inéditas, de um personagem infantil e outro feminino na trama. A ausência de crianças e/ou jovens até esse momento é realmente um fato que chama a atenção na medida em que desde seus primeiros contos Veiga tem sido pródigo em povoar seus enredos com adolescentes e crianças, sempre de maneira sensível e sem véus de idealização, como demonstram a quase totalidade das narrativas dos dois livros de contos.

Essa característica, com uma ou outra exceção, também se manterá nos livros posteriores ao A hora dos ruminantes, e por este mesmo motivo, inclusive, até hoje

\footnotetext{
${ }^{77}$ VEIGA, José J. Op. cit. p. 49.
} 
alguns leitores pouco atentos às peculiaridades do escritor e de seus enredos, interpretam essa sua característica como a de um autor de literatura infanto-juvenil, como se essa categoria fosse suficiente para explicar todas as questões, todos os problemas de forma e conteúdo, todos os impasses que a produção ficcional de Veiga veio suscitar no meio literário dos anos 60 e que de certa maneira permanece causando curiosidade e interesse até hoje. Esse aspecto da recepção já fora citado, por exemplo, por Iza Quelhas, em artigo retirado de seu importante trabalho sobre o escritor:

Identifica-se dois "rótulos" que condicionaram, de certa forma, a recepção da obra de José J. Veiga: primeiro, o conceito então vigente de literatura juvenil, no qual a predominância do olhar de um narrador infantil definiria a idade de seu leitor. Essa classificação, por sua vez, restringe e ameniza a problematização da infância e os modos possíveis de recriar a narrativa, elaborados pelo autor. ${ }^{78}$

Já a ausência de personagens femininos não se pode dizer que seja algo raro na produção veiguiana; pelo contrário, é um traço comum nos três primeiros livros do autor, o que indica, evidentemente, o caráter patriarcal presente nessas narrativas. Não seria incorreto dizer, inclusive, que o personagem feminino de maior destaque na produção literária de Veiga só irá surgir no romance Sombras de reis barbudos, de 1972. Até lá, o comum será encontrar personagens femininos que representam bem a posição da mulher dentro dessas estruturas sociais mais arcaicas, posições hierarquicamente inferiorizadas às do marido e de obediência às determinações dele.

É esse o caso específico de D. Serena que mais parece uma figura utilizada para a composição de um quadro, na medida em que a família do ferreiro é a única estrutura

${ }^{78}$ QUELHAS, Iza. "No país do faz de conta: uma leitura da obra de José J. Veiga". In Recorte Revista de Linguagem, Cultura e Discurso, UNINCOR, Três Corações - MG, Ano 2, no 3, 2005, p. 2. O texto é uma condensação da dissertação de mestrado Hera, muros \& ruínas: a alegoria na obra de José J. Veiga. UFRJ, 1990. 
familiar visível na narrativa. Como foi dito, a família do ferreiro voltou a sua rotina após o incidente do menino com os estranhos. Já havia quase esquecido o assunto quando, um dia, Geminiano passou na oficina de Apolinário e o avisou que os homens da tapera queriam vê-lo. Apolinário, assim como fizera anteriormente Manuel Florêncio, observa Geminiano na boléia da carroça com um misto de compadecimento e aversão e sua resposta, polida, é a de que costuma combinar serviço somente na oficina, o que não indica, a priori, indisposição em atender os forasteiros.

A informação de Geminiano, no entanto, é a de que eles não querem combinar serviço e sim conversar com o ferreiro. A informação é suficiente para mudar a disposição de Apolinário que responde negativamente ao recado e permanece mal humorado pelo resto da manhã. Ao chegar para o almoço em sua casa, o assunto do recado já não era mais novidade, e da mesma forma que D. Serena já sabia do ocorrido, outras tantas pessoas também estavam ciente. A mulher, agora mais preocupada ainda com os estranhos, sugere uma pequena viagem para o sítio do irmão, proposta prontamente rechaçada por Apolinário.

À tarde, na oficina, o ferreiro recebe a visita de Manuel Florêncio que viera fazer encomenda de um instrumento de trabalho. Após a entrega das medidas do instrumento, Manuel entabula uma prosa com Apolinário e cita as contrariedades que tem passado nos últimos dias. Apolinário demonstra desconhecimento do que ocorrera dois dias antes com Manuel e esse fato indica um comportamento não afeito ao diz-que-diz da maioria dos manarairenses ou, pelo menos, indica que não é da índole do ferreiro participar das rodas de fofoca. Por outro lado, embora não fique evidente, o leitor percebe que Manuel Florêncio parece saber do ocorrido com Apolinário e esse mesmo sentimento é compartilhado pelo ferreiro que o olha desconfiado e sentencia: “-Comigo perdem tempo. Meu ofício é malhar ferro." 79

\footnotetext{
${ }^{79}$ VEIGA, José, J. Op. cit., p. 55.
} 
A frase mergulha Manuel Florêncio numa reflexão silenciosa e profunda sobre a possibilidade não só de cada pessoa assimilar as características da profissão escolhida, mas também na possibilidade de todo indivíduo ir ganhando propriedades do material específico com que trabalha. A reflexão do marceneiro parece retomar num nível mais reflexivo, dadas as características do personagem, um pouco da idéia do processo de reificação que se viu operar de maneira concreta e violenta em Geminiano.

Manuel pensou no seu ofício de cortar madeira, comparou os dois materiais. A diferença teria algum efeito na resistência das pessoas que lidam com um e outro? (...)

E será também que o costume de lidar sempre com o mesmo material entra ano sai ano não vai influindo na alma da pessoa, contagiando moleza ou dureza? Reparando bem, parece que cada um vai apanhando cara do ofício que desempenha. ${ }^{80}$

A observação do rosto de Apolinário, os gestos da sua atividade, a comparação com outros ofícios, tudo isso é matéria de reflexão de Manuel Florêncio em mais um momento de lirismo e consciência crítica do personagem. Se o leitor pressentia que Manuel viera ali a fim de influenciar Apolinário a ceder ao chamamento dos estranhos, agora tem a certeza de que não é essa a intenção do marceneiro. Além disso, a confiança demonstrada por Apolinário consola Manuel da sua própria fraqueza ao se submeter à vontade dos forasteiros. Ao sair da oficina de Apolinário Manuel tem a firme convicção de que o ferreiro será um páreo duro para os estranhos, impressão que será formulada mais adiante, quando convocado a opinar sobre o caso na mercearia de Amâncio Mendes.

Os dias passam sem que os estranhos procurem Apolinário, o que faz com que a atitude do ferreiro seja comentada por toda cidade e ele "apontado como um homem de

\footnotetext{
${ }^{80}$ Op. cit., pp. 55-56.
} 
brio, uma lição para todos, um exemplo para quem quisesse seguir" ${ }^{81}$. Apesar da fama, porém, um novo contato dos forasteiros não tarda. Num dia em que se encontra sozinho Apolinário terá outra visita de Geminiano, desta vez lhe trazendo um bilhete sem envelope cuja resposta, segundo o carroceiro, é aguardada pelos homens. O ferreiro, no entanto, tem preocupações mais urgentes, necessidades do dia a dia, outras atividades, uma sela para cavalo. Apolinário concentra-se na atividade prática e o narrador numa de suas mudanças peculiares, assume a posição do artesão que molda o ferro com o fogo, num movimento em que se mesclam força e delicadeza.

A idéia de Geminiano, porém, era a de recolher a resposta na volta à fazenda, ao que é surpreendido pela informação de que Apolinário sequer lera o bilhete. $\mathrm{O}$ carroceiro se irrita com o descaso do ferreiro, que por sua vez também demonstrará sua exasperação com a insistência por parte de Geminiano e, principalmente, pela atitude autoritária dos forasteiros de quererem voluntariosamente interromper seu trabalho.

- Importante para mim é o meu serviço. Quando me der na veneta eu abro o papel e leio. Serve assim? Se serve, muito bem. Se não serve, leve de volta. Aqui ele não faz falta. ${ }^{82}$

A insistência de Geminiano e a tonalidade imperativa da sua fala, adquirida do hábito de lidar com os estranhos exaspera de tal modo Apolinário que o bilhete será queimado sem que leitor e personagens fiquem sabendo de seu conteúdo. A reação estupefata de Geminiano é de alertar o ferreiro sobre um futuro atrito com os forasteiros por essa atitude e a expectativa tensa desse encontro irá se avolumando na narrativa a partir dessa cena.

Após a partida de Geminiano Dias para o acampamento, o foco narrativo permanece na oficina do ferreiro induzindo o leitor a perceber, além do objeto bem

\footnotetext{
${ }^{81}$ Op. cit., p. 58.
}

${ }^{82}$ Op. cit., p. 60. 
feito, a pouca preocupação do personagem com aquilo que não seja o seu trabalho. Embalado pela boa armação de sela que fizera após o caso do bilhete, Apolinário resolve aproveitar as medidas para confeccionar mais duas ou três peças. Mais tarde, enquanto lavava-se, recebe a visita de Amâncio Mendes, num prenúncio, para o leitor, de mais uma investida dos forasteiros. Depois de elogiar a peça que o ferreiro acabara de fazer, o vendeiro introduz sem muita cerimônia o assunto que o trazia ali: o bilhete queimado sem leitura e sem resposta.

Obviamente, a relação entre esses dois personagens não tem o mesmo grau de amizade que observáramos anteriormente entre Manuel e Amâncio. Ainda assim as frases são ditas de maneira objetiva e direta, numa franqueza que acaba desnudando comportamentos nada elogiáveis:

- Você agiu muito mal. Então os homens lhe mandam um bilhete, você pega e queima o bilhete sem ler? Onde é que você estava com a cabeça? Fazer uma desfeita dessa, e logo com quem!

- E você se queimou por quê? Até parece que você estava dentro do bilhete. (...)

- Você não precisa ter tanto medo deles. Até que eles ainda não fizeram mal a ninguém. São gente educada, sabem conversar sem ofender. Você ia lá, conversava, se explicava. (...)

- Amâncio, eu não quero the criticar porque não sei onde sua botina aperta. Mas eu cá não preciso sabucar ninguém e não tenho nada a explicar. Eles podem esperar até o Chico vir de baixo que eu lá não vou. Se vierem aqui e falarem direito, posso atender; mas se vierem com rompantes, viram nos cascos na mesma hora. ${ }^{83}$

A peleja verbal entre os dois personagens permanece, Amâncio arrolando os motivos para que Apolinário aceite o chamado dos forasteiros, e o ferreiro justificando sua atitude como a mais adequada ao comportamento arrogante e autoritário dos

\footnotetext{
${ }^{83}$ Op. cit., pp. 61-62.
} 
estranhos. Desse primeiro contato com Apolinário Amâncio sai derrotado, embora não totalmente insatisfeito, pois fizera o que os forasteiros esperavam dele, se esforçara para convencer o ferreiro a visitá-los.

Numa cidade acostumada a observar tudo e todos, a notícia da postura firme de Apolinário frente a Amâncio reforça ainda mais o alto conceito com que é referido por todos. A incógnita para a cidade fica não só por conta da falta de reação de Amâncio, mas também pelo seu interesse "em se intrometer na pendenga entre Apolinário e os homens" ${ }^{84}$, ainda mais por estar ao lado dos estrangeiros em um novo enfrentamento entre os dois grupos.

Naquele mesmo dia, ao cair da noite, enquanto os manarairenses ainda comentavam sobre a coragem do ferreiro em dizer algumas verdades a Amâncio, a mercearia recebe a visita de dois dos forasteiros. O vendeiro, após dispensar os freqüentadores habituais, fecha seu comércio mediante sugestão dos estranhos. Depois de alguns instantes de conversa em baixo tom, Amâncio sai apressadamente à procura de Apolinário.

O ferreiro "estava na esquina do pombal velho conversando com amigos" ${ }^{85}$; ao verem o comerciante passar, um deles chama Amâncio avisando-o da presença de Apolinário. O momento é de nova investida do comerciante e na sua concentrada intenção desconsidera até mesmo a presença das demais pessoas do grupo: "- Vem comigo. Tem gente na venda querendo conversar com você. Vamos depressa." ${ }^{86}$ A reação de Apolinário é igual à anterior: informando a Amâncio de que nada tinha a conversar com os estranhos, o ferreiro não se move do lugar.

Como deve ter sido incumbido da tarefa de levar Apolinário a qualquer custo, o vendeiro é ostensivamente insistente no seu objetivo, e para tanto lança mão de diversos

\footnotetext{
${ }^{84}$ Op. cit., p. 63.

${ }^{85}$ Op. cit., p. 64.

${ }^{86}$ Op. cit., p. 65.
} 
recursos, o que chega, inclusive, a provocar a reação de um dos que presenciavam o diálogo. Esgotadas as opções de argumentos para convencer o ferreiro a se deslocar até a mercearia, Amâncio Mendes irá recorrer ao mesmo recurso que utilizara no caso de Manuel Florêncio, ou seja, trará a discussão para o nível pessoal utilizando mais uma vez como mecanismo de persuasão a relação de favor, agora vista pelo seu reverso; ou seja, se no caso de Manuel o vendeiro pedira um favor, agora no caso de Apolinário, Amâncio irá cobrar um favor:

- Me admiro você, Apolinário. Sempre fomos amigos. Lembra quando você esteve de cama com pneumonia e eu lhe forneci de tudo fiado? Agora que preciso de você, você tira o corpo fora. Você pensa que a barriga dói é uma vez só? ${ }^{87}$

A cobrança é contundente para um caráter como o de Apolinário. Reconhecendo a dívida pessoal que tinha com o comerciante, o ferreiro concorda em ir à mercearia, mas deixando claro que fazia aquilo como pagamento do favor recebido. Embora Amâncio ainda procure consertar a situação colocando-se como aquele que necessita da colaboração alheia, a frase já fora dita causando mesmo um grande desconforto no vendeiro, num dos poucos momentos em que o leitor percebe alguma insatisfação de Amâncio com o papel que escolheu desempenhar:

Amâncio já sentia que não tinha ganhado uma vitória; pelo contrário, estava arrependido do papel que fizera na frente de outras pessoas. Tudo por causa daqueles homens, mal de seus pecados. Por que não fizera como Apolinário vinha fazendo? Agora era responsável também pela derrota de Apolinário. ${ }^{88}$

\footnotetext{
${ }^{87}$ Op. cit., p. 66.
}

${ }^{88}$ Op. cit., p. 67. 
Momento de grande tensão na história, Apolinário caminha com desenvoltura e segurança ao encontro dos estranhos em simétrica oposição a Amâncio que parece ter perdido toda a pressa e ânimo que antes demonstrava. Os dois chegam à mercearia e encontram os estranhos numa cena incomum: sentados lado a lado no balcão, balançando as pernas, um deles ocupado com uma pequena caixa de marmelada e o outro fatiando uma peça de queijo, se deliciavam com a combinação gastronômica. Mesmo com a chegada de Apolinário e Amâncio, os dois estranhos não alteram o comportamento nem cessam a comilança, o que traz certo ar patético à cena.

Enquanto eles encerram a merenda, Apolinário se acomoda num canto da mercearia ao mesmo tempo em que Amâncio retoma seu comportamento servil. A demora para que os forasteiros comecem a falar ainda se prolonga após o lanche e é necessário que Amâncio, já incomodado com a situação, introduza o assunto e apresente Apolinário aos forasteiros que parecem menos empenhados em discutir o caso que fazer a digestão.

Há, inclusive, uma pequena discussão entre os dois estranhos para ver quem é que começa o diálogo com Apolinário, cada um deles parecendo não querer se envolver com o assunto. Após isso, o ferreiro ainda espera um momento até que alguém tome a iniciativa propriamente dita. Fora da mercearia o burburinho é constante, as pessoas querendo saber o que se passa naquela reunião incomum e demasiadamente silenciosa. A sensação de todos é de um atrito iminente.

A conversa, enfim, tem início e pela primeira vez na história o leitor saberá dos estranhos com informações ditas por eles mesmos, embora essas informações não sejam mais do que aquilo que o leitor já conhece. Quem dá as informações, ao mesmo tempo em que esboça um interrogatório para Apolinário, é o estranho identificado pelo sobrenome de Neiva. 
A certa altura de seu discurso, o colega que permanecera calado critica Neiva por estar demorando demais nas perguntas, ao que é retrucado com uma provocação em nível pessoal. O interrogatório de Apolinário é, então, interrompido para que os estranhos resolvam suas diferenças num pequeno bate-boca em mais uma representação das relações de alteridade desorganizadas e desrespeitosas.

A retomada das perguntas ocorre rapidamente, mas ainda assim o depoimento de Apolinário terá pouco desenvolvimento: interrompido novamente pelo colega que insiste na afirmação de que o depoimento está sendo mal conduzido, com perguntas muito extensas e desnecessárias, Neiva anuncia o final do interrogatório:

— Está tudo errado - disse o Chaves. - Essa pergunta vem no fim. Olhe aí, seu Amâncio. Eu não disse que ele não podia fazer esse serviço? (...)

- É? Então agora eu não pergunto mais nada. Acabou-se o interrogatório, pronto. Sr. Apolinário, o senhor está livre. Pode ir embora. Pode ir por minha conta. ${ }^{89}$

Toda a tensão crescente ao longo de várias páginas e cenas elaboradas parece se esvair no ridículo desse momento inusitado da narrativa. $\mathrm{O}$ ferreiro Apolinário contém com esforço o riso ("Rir a gente ri só com amigos") e mesmo Amâncio Mendes se mostra vexado com o sem sentido do comportamento dos forasteiros.

Realmente há um forte sentimento de ludibrio com o fecho do encontro na mercearia, na medida em que ele não repete certo movimento de cooptação dos personagens, estruturalmente presente desde o início da trama. O riso parece destruir toda essa provável estrutura de cooptação além de evidenciar o verdadeiro caráter estranho que envolve os homens da tapera: a estranheza não decorre propriamente dos forasteiros nem de suas atitudes, mas sim da posição distanciada do narrador em relação ao seu objeto de representação, o que imprimia um aspecto insólito e de super potência

\footnotetext{
${ }^{89}$ Op. cit., p. 70.
} 
a esse objeto quando na verdade tratava-se de pessoas quase tão toscas como a média dos cidadãos manarairenses.

Portanto, a transformação que acontece não se dá no objeto em si, mas sim devido à aproximação da voz narrativa que desta vez acompanha o personagem. Observados de longe, desfocados, a mercê de julgamentos e interferências subjetivas, interesseiras ou não, os forasteiros se mostravam como aquilo que efetivamente não eram; a aproximação de Apolinário, acompanhado pelo narrador, retira o véu de estranheza e insólito que cobria o olhar manarairense e que impedia de ver a real natureza dos forasteiros: homens comuns, cumpridores de tarefas, burocratas desorganizados, arrogantes e ridículos, presos a picuinhas e acostumados a aterrorizar pessoas humildes com posturas autoritárias de quem é a lei num lugar em que esta lei parece não existir.

O movimento do foco narrativo, além de desnudar o verdadeiro caráter dos invasores, evidencia a construção técnica da matéria e seu caráter ficcional. Ao fazê-lo acaba também expondo as limitações das possibilidades de representação dessa matéria dada à precariedade do meio e das relações sociais aí presentes. Nesse sentido é que a situação de um narrador com uma onisciência parcial e uma visão limitada aos espaços do coletivo garante um nível particular de representação da realidade que talvez não fosse possível alcançar caso o narrador se mantivesse numa posição tradicional de onisciência plena. Como afirma Anatol Rosenfeld:

Uma época com todos os valores em transição e por isso incoerentes, uma realidade que deixou de ser "um mundo explicado", exigem adaptações estéticas capazes de incorporar o estado de fluxo e insegurança dentro da própria estrutura da obra. ${ }^{90}$

${ }^{90}$ ROSENFELD, Anatol. "Reflexões sobre o romance moderno". In Texto/Contexto I. $5^{\text {a }}$ ed., São Paulo, Perspectiva, 199, p. 86. 
Se optasse por uma representação mais tradicional desse meio, com o narrador posicionado por cima ou por dentro, mas com uma onisciência total, mediadora entre os personagens e o mundo, a obra poderia cair no clichê regionalista de caráter documental e particularista sem conseguir mimetizar a particularidade da visão de mundo dessas comunidades perdidas no Centro-Oeste antes da chegada da ideologia desenvolvimentista na região.

O escritor, ao tratar de um assunto recorrente em nossa literatura, a configuração da cor local, obedece não só a um impulso subjetivo, dada sua origem e formação de leitor e intelectual, mas também ao impulso inato de nossa produção literária. No entanto, ao que parece, não era sua intenção apenas descrever essa cor local, o que seria a mera reprodução da fórmula já gasta do regionalismo. Além disso, esse retrato já fora feito anteriormente de maneira satisfatória, através de uma configuração às vezes mais naturalista, às vezes mais social.

Aceitar essa matéria é ao mesmo tempo aceitar o desafio de uma evolução formal para ela. A voz narrativa ao se descentralizar, tornando sua visão móvel, mas limitada, igualando-a a visão daqueles que quer representar, avança no sentido de tentar uma configuração menos idealizada e mais veraz dessa matéria, mesmo que para isso opere um processo que se caracteriza pela desrealização. Segundo Rosenfeld,

(...) tradicionalmente coube ao narrador, como eixo em torno do qual revolve a narração, garantir a ordem significativa da obra e do mundo narrado. No entanto, se esta ordem é posta em dúvida, a ausência do organizador e a supressa de uma ordem ilusória certamente se justificam. ${ }^{91}$

O narrador, portanto, passa a contar a estória do ponto de vista da coletividade configurando os forasteiros como um enigma devido à visão tacanha e amedrontada dos manarairenses; o leitor, por sua vez, se sente incomodado com o que lhe parece

\footnotetext{
${ }^{91}$ Op. cit., p. 84.
} 
estranho, ou seja, a limitação da voz narrativa que em nenhum momento se eleva para descrever objetivamente os forasteiros. Esses, portanto, aparecem na narrativa para o leitor da mesma maneira que surgem aos olhos dos manarairenses: incompreensíveis.

Embora não se possa falar propriamente em vitória de Apolinário, na medida em que ele está inserido, assim como a coletividade num movimento maior de mudança do qual, aliás, têm pouca ciência - pode-se falar legitimamente de um movimento de resistência. Não de uma resistência teórica e cheias de boas intenções, atrelada a procedimentos concretos que a denunciam como logro, mas de uma resistência concreta que se baseie num ajustamento da perspectiva e num bom manuseio da palavra e do silêncio. A resistência de Apolinário aos mecanismos de cooptação que se reproduziam parece jogar luzes sobre a real natureza dos estranhos, expondo-os, ao olhar espantado do leitor, em toda sua inteireza de embuste.

Mas o segundo capítulo ainda não se encerra nesse instante e esse fato também acaba por trazer uma diferença significativa no que diz respeito à extensão das três partes do livro e o equilíbrio delas. Ao término da ocorrência com o ferreiro, o narrador introduz um grupo a mais de personagens que não havia, até então, tido qualquer participação na trama, nem mesmo sendo citados nominalmente. A introdução deles nesse momento da estória é ainda curiosa porque são personagens distintos daqueles apresentados ao leitor até esse instante, personagens revestidos de certa tipificação a compor o retrato de cidade do interior como os tipos do caçador, comerciante, carroceiro, padre, marceneiro, ferreiro, etc.

Ao mesmo tempo, o leitor tem a impressão que esses personagens recém introduzidos se encaixariam sem muitos problemas no universo de caracteres dos contos do escritor, de Os cavalinhos de Platiplanto ou de A estranha máquina extraviada, 
povoados de jovens, alguns órfãos, enfrentando os desafios de um mundo adulto que deteriora os sentimentos infantis e imprime uma crueldade incompreensível a esses pequenos anti-heróis.

Os personagens nesse caso atendem pelos nomes de D. Bita, Nazaré e Pedrinho. D. Bita vive com sua afilhada, ou filha adotiva, Nazaré que começa um namoro com Pedrinho, jovem órfão de pai e mãe que trabalha na loja de miudezas de seu Quinel. O narrador conta o início do namoro pueril dos jovens e as primeiras dificuldades e empecilhos criados pelos olhares curiosos da cidade e pelo próprio sentimento exclusivista daquela paixão. No intuito de escaparem dessa observação atenta e moralizadora, os jovens procuram lugares cada vez mais ermos e discretos nas redondezas da cidade. É assim que, certo dia, estando de namoro "na sombra de um bambuzal no caminho do Poço do Gado" ${ }^{92}$, o casal vê dois homens passando numa caleche, uma carruagem comum de quatro rodas. Os estranhos interrompem a viagem e abordam os jovens que ficam surpresos com a atitude. De maneira imperativa um dos estranhos convoca Pedrinho a aproximar-se; depois de alertar o jovem que o lugar onde o casal estava não era o mais adequado "para esse gênero de atividade", o forasteiro faz o convite:

- Por que vocês não vão namorar lá na tapera? Lá é ótimo. Tem bancos, tem rede, vocês ficam à vontade; ninguém incomoda. ${ }^{93}$

Apesar do incomum da situação e da surpresa do convite, os adolescentes aceitam a oferta. Um dos forasteiros improvisa assento para os jovens e eles são vistos, aparentando satisfação, por toda cidade no momento em que o veículo passa no largo central.

\footnotetext{
${ }^{92}$ Op. cit., p. 79.
}

${ }^{93}$ Op. cit., p. 80. 
O leitor, portanto, se vê inserido num outro ponto de vista do enredo - com personagens estreantes nas últimas trinta páginas da narrativa - e incerto do significado da aparente vitória de Apolinário. Além disso, de maneira pouco usual dentro da narrativa até o presente momento, o próprio desfecho da visita dos jovens ao acampamento fica suspenso.

A alteração do sentimento amoroso de Nazaré no momento em que adentra o território dos estranhos é a mesma alteração que ocorre em tudo aquilo em que os forasteiros colocam sua sombra, imprimindo a marca do desajuste, da estranheza e do desacordo entre os homens e o mundo. No terceiro capítulo, a degeneração do sentimento de Nazaré é uma degeneração interna àquela ocorrida em toda a Natureza no surgimento inexplicável dos ruminantes;

\subsection{Perdas e ruínas: a reconfiguração do mundo}

É de se reparar com certa facilidade que o derradeiro capítulo do livro é estruturalmente e figurativamente distinto dos anteriores. A ação dos personagens é mínima e, não fosse a necessidade de se dar um fecho cabal à ocorrência com o casal Nazaré-Pedrinho, essa ação seria ainda mais reduzida.

Isso acontece, é claro, devido à dedicação do narrador em construir uma grande imagem fúnebre envolvendo toda Manarairema e que num primeiro momento parece 
conotar o fim da coletividade que, oprimida fisicamente, emparedada de maneira literal, possui, de fato, poucas possibilidades de ação. Isso acaba também sendo determinante para que este capítulo seja o mais breve da história, já que é o mais descritivo e predominantemente estático. A imagem de morte é elaborada a partir da operação multiplicadora de um animal vital ao homem, o boi, que também é, há décadas, símbolo da região que, supõe-se, serve de cenário geral não só dessa narrativa, mas basicamente de quase toda a obra do escritor

Diferentemente do que ocorrera com os cachorros, que chegaram de uma vez, num derrame, a presença dos bois se dá de maneira paulatina "aparecendo aqui, ali, nas encostas, nas serras, nas várzeas, na beira das estradas." ${ }^{94}$ Outro dado distintivo diz respeito à origem dos bichos, pois no caso dos cães tanto o leitor quantos os personagens estão cientes de onde eles vêm, o acampamento dos forasteiros, ao passo que as "marcas que [os bois] mostravam nada esclareciam, ou eram desconhecidas na região ou muito apagadas, difíceis de serem recompostas." ${ }^{95}$ Pensando se tratar de animais desgarrados de seus rebanhos, a população não atenta devidamente à presença cada vez maior dos bovinos. Eles enchem as estradas, atravessam o rio, chegam às ruas, ao largo da cidade

e quando o povo percebeu o que estava acontecendo já não era possível fazer nada: bois deitados nos caminhos, atrapalhando a passagem, assustando senhoras; as entradas do largo entupidas e mais bois chegando como convocados por uma buzina que só eles ouviam; os que não cabiam mais no largo iam sobrando para as ruas de perto, para os becos e terrenos vazios. ${ }^{96}$

\footnotetext{
${ }^{94}$ Op. cit., p. 83.

${ }^{95}$ Op. cit., p. 83.

${ }^{96}$ Op. cit., pp. 83-84.
} 
A partir dessa introdução e ao longo das páginas seguintes, ocupando praticamente metade deste capítulo final, o narrador constrói gradativamente essa imagem de opressão e horror que é o emparedamento das pessoas numa perspectiva de esmagamento iminente. Os bois vão se multiplicando até formar uma massa compacta que ocupa todos os espaços pressionando muros e destroçando paredes.

Acuados e isolados em suas casas, os manarairenses só conseguem se contatar através de um artifício criativo e perigoso praticado pelos garotos da cidade:

Descalços e munidos de uma vara tendo numa ponta uma plaquinha acolchoada, os meninos subiam numa janela, daí passavam para o lombo de um boi, e utilizando a vara como escora iam navegando por cima deles, transmitindo e recebendo recados e encomendas, apostando corridas uns com os outros. ${ }^{97}$

Aproveitando o expediente "o agente do correio organizou um serviço de recados para toda a cidade", dividindo os garotos em atividades específicas de entrega e recolhimento de mensagens e encomendas, estabelecendo certa ordem na desordem num recorte meio cômico, meio amargo; a improvisação dos garotos traz o perigo da morte, alguns se desequilibram e acabam escorregando por entre os animais "sujando-se nas bozerras, molhando-se nas poças de urina, sangrando as mãos e os joelhos nas pedrinhas do chão até alcançarem um abrigo." 98 Outros, no entanto, se desorientam, assustam os animais e acabam sendo "esmagados por aquelas mãos-de-pilão de muitas arrobas de peso." 99

Os cheiros misturados de pêlos, chifres, suor, urina e estrume vão se intensificando e empesteando o ar, causando tonturas, enjôos e vômitos nas pessoas:

\footnotetext{
${ }^{97}$ Op. cit., p. 85.

${ }^{98}$ Op. cit., p. 85.

${ }^{99}$ Op. cit., p. 85.
} 
"Tudo o que se comia ou bebia, até aguardente, vinha com aquele cheiro azedo que o povo foi associando ao cheiro da morte." 100

A intervenção religiosa é reclamada em forma de apelos por orações e ladainhas, mas o representante divino se mostra incapaz de agir dada toda aquela inversão da ordem natural das coisas. Por conceber ainda uma explicação mítica para todo o horror sofrido pela cidade (“- Força maior, Balduíno. Vontade de Deus.” 101), padre Prudente volta a atenção para sua coleção de selos, numa forte conotação de impotência e desorientação.

Em meio a toda desordem e ao desânimo geral, o narrador insere a conclusão do caso Nazaré-Pedrinho. Na verdade, essa inserção se dá em dois momentos do capítulo com os retornos gradativos do rapaz e da moça. O leitor ficará sabendo, então, o que ocorrera após o rapto consentido e insensato dos jovens, e esse será o primeiro depoimento de alguém que esteve no acampamento. Segundo Pedrinho, depois que lá chegou, o casal de namorados foi separado; os estranhos levaram Nazaré para dentro da casa enquanto ele se debatia na tentativa de reagir aos que o amarravam e amordaçavam:

- Eles tomaram ela de mim. Levaram lá para dentro. Eu reagi. Muitos me seguraram. Eu gritei, xinguei, mordi. Eles me amarraram. Ela ajudou. Nazaré ajudou. Entupiram minha boca com panos. Ela ajudou. Me jogaram numa grota no quintal. Olhe as marcas das cordas. Me davam comida numa gamela no chão. Eu tinha de comer enfiando a cara, como cachorro. Ela ficava perto olhando, de vez em quando empurrava a gamela para longe com o pé, só para me ver me arrastar no chão. ${ }^{102}$

Mais uma vez, e agora de maneira contundente, o espaço ocupado pelos forasteiros se mostra portador de uma malignidade deformadora que neste caso agirá

\footnotetext{
${ }^{100}$ Op. cit., p. 94.

${ }^{101}$ Op. cit., p. 85.

${ }^{102}$ Op. cit., p. 90.
} 
sobre as emoções e o comportamento de Nazaré, transformando um sentimento amoroso juvenil e ingênuo numa sensualidade exacerbada com pitadas de sadismo:

- E ela?

- Lá com eles. [...]

- Pedrinho, diga a verdade. O que foi que você fez com aminha menina?

- Eu não. Eles.

- Eles? Fizeram o quê?

- Fizeram. A senhora sabe. ${ }^{103}$

Dentro de um arruinamento maior, o da natureza, com as invasões dos cachorros e, principalmente, a dos bois, o narrador figura de maneira explícita na transformação corruptora que se opera no comportamento e personalidade de Nazaré, a perversão sexual como ruína do sentimento amoroso.

Porém, apesar desse momento da estória acabar confirmando o que até agora era especulação, o fato de explicitar, de deixar evidente o espaço cheio de negatividade dos forasteiros, parece enfraquecer o enredo na medida em que uma das qualidades dele era justamente o poder de sugestão dos eventos sem a necessidade (ou devido à impossibilidade) de uma exposição minuciosa dos fatos e do ambiente, como ocorre agora na caracterização dos estranhos como pervertidos.

Esse aspecto, aliado à observação da distinção estrutural que existe entre o caso dos jovens e as experiências conflituosas dos demais personagens para com os estranhos, nos dá a impressão de que a ocorrência envolvendo D. Bita, Nazaré e Pedrinho funciona mais como uma narrativa independente desse conflito central e coletivo. Um pouco ao sabor das narrativas curtas do primeiro livro do escritor, que enfocam as experiências infantis e juvenis numa ambientação hostil, a história do amor de Nazaré e Pedrinho dá a impressão de uma história menor que se agrega à outra por

${ }^{103}$ Op. cit., p. 90. 
apresentar alguns pontos de contatos que nem sempre dão solidez ou garantem a continuidade adequada à estória das invasões em Manarairema.

Os dois momentos de retorno dos jovens são, no entanto, rápidos, pois a principal preocupação do narrador nesta última parte é a construção de uma imagem quase completa do que parece ser o fim da coletividade manarairense. Num capítulo, como se disse, sem ação, estático, a figura dominante é a da morte, estampada no relógio que desacelera e cessa seu ritmo, numa demonstração angustiante do fim dos tempos (“O relógio da igreja não batia mais (...) dentro de pouco tempo não haveria mais nem horas para marcar." ${ }^{104}$ )

Fisicamente exauridos (“Enfraquecidos pela fome e pelos vômitos freqüentes”), abalados psicologicamente ("Na Rua da Pedra um homem enlouqueceu, saiu de casa agredindo bois a murros"), os habitantes da cidade não possuem meios de reação e sobrevivem como emparedados vivos ("sobrevivências inúteis de uma época já distante e irrecuperável" ${ }^{105}$ ).

A escassez de alimentos e água potável, o cheiro nauseabundo, a pressão emocional e psicológica, tudo parece indicar o definhamento da cidade ("Manarairema já estava no limiar da morte") e a imagem da dissolução avança sobre todos até se concretizar na grande noite com seu manto acolhedor anunciada pelo narrador (“A noite baixou solene, afinal. Quase ninguém acendeu as luzes [...] Também se a noite única não ia tardar, pouca diferença podiam fazer algumas velas e candeeiros" ${ }^{106}$ ).

O leitor mais atento há de lembrar que a idéia e imagem da noite como momento de provação já havia sido anunciada e construída nos dois primeiros parágrafos da

\footnotetext{
${ }^{104}$ Op. cit., p. 93.

${ }^{105}$ Op. cit., p. 94.

${ }^{106}$ Op. cit., p. 94.
} 
estória, inclusive se valendo de um procedimento na elaboração dessa imagem que faz recordar certo poema bastante conhecido:

(...) Manarairema ao cair da noite - anúncios, prenúncios, bulícios.

(...) morcegos costurando a esmo, estendendo panos pretos, enfeitando o largo para alguma festa soturna. Manarairema vai sofrer a noite. ${ }^{107}$

Ao invés de cantos de galos tecendo a luz da manhã e trazendo a claridade do dia, ocorre aqui a imagem inversa de animais noturnos encobrindo tudo com suas asas negras, anunciando um porvir de dificuldades.

É eloqüente a imagem da morte no final da narrativa, elaborado pelo amálgama da escuridão e da massa compacta de milhares de bois, animal milenarmente indissociável da vida e do trabalho humano e carregado de significação tanto da relação do homem com a terra, quanto da relação de domínio humano sobre os elementos naturais. Essa multiplicação extraordinária e mortífera parece querer dizer da dissolução total dessas relações na medida em que avulta a perda de controle de tudo o que se achava natural.

Fica aí evidente, de uma vez por todas, aquilo que o leitor já havia percebido desde o início do livro com a chegada e a instalação gradativa dos forasteiros na cidade: a decomposição das relações sociais dos manarairenses e, de modo mais abrangente, das relações de homem e natureza, fato sentido por toda a população em vários aspectos do cotidiano e cujos exemplos mais contundentes são configurados nas ocorrências com os personagens postos em destaque, com a perda do mando de suas próprias ações, numa representação individualizada do descontrole que iria se generalizar.

O aparecimento dos ruminantes surge, então, como indício do arruinamento da natureza que envolve a coletividade manarairense. O boi, que ligado à vida do ser humano prefigura o caráter domesticado da natureza, a relação de domínio humano, ${ }^{107}$ Op. cit., p. 1. 
racional, sobre o meio natural acaba por representar a destruição do homem e da própria natureza, o boi portador da morte, numa inversão das coisas que beira o insuportável:

O mundo era dos bois, não havia espaço para outros bichos, coitados dos tatus e preás, perdizes e seriemas, até as formigas, até os peixes, esses incapazes de nadar nos rios entupidos. ${ }^{108}$

No percurso dessa presente leitura de $A$ hora dos ruminantes percebe-se que o termo fantástico foi poucas vezes utilizado, justamente na tentativa de fortalecer o tratamento de caráter realista que predomina na obra, pelo menos até o surgimento dos bovinos e apesar do estranhamento que pontua o enredo desde a chegada dos forasteiros, estranhamento, como se viu, causado em grande parte pela limitação proposital do olhar do narrador que causa um embaralhamento no enfoque do objeto..

É, com efeito, o surgimento dos bois que motiva algumas leituras da narrativa como um possível exemplo de literatura fantástica na medida em que o surgimento dos animais parece desafiar e exigir do leitor uma explicação coerente e minimamente articulada ao percurso narrativo precedente, uma explicação que, apesar das dificuldades, o leitor conseguira nos momentos insólitos anteriores, mas que parece agora de improvável alcance devido à opacidade da imagem dos bois feito uma massa uniforme que parece embotar os níveis de compreensão utilizados até então para a interpretação da estória.

O próprio escritor comentou em vários momentos da sua vida a questão da recepção da sua obra como literatura fantástica. Num seminário em 1987, Veiga expressou o seguinte:

(...) veja esses escritores chamados latino-americanos. Eles estavam ai perto, escrevendo. E nós, os brasileiros, leitores, criticos, etc., não sabíamos, não é? Depois que eles foram descobertos e divulgados pelos

${ }^{108}$ Op. cit., p. 88. 
europeus, principalmente pelos franceses, é que eles passaram a ser lidos no Brasil. Então foi uma espécie de um espelho que se refletiu para cá (...) todo mundo passou a falar neles, as editores traduziram, etc. De maneira que essa conceituação, também é ela muito européia. Eu acho que isso foi herdado, não foi uma criação brasileira. ${ }^{109}$

A consciência do escritor sobre a questão do ponto de vista para um entendimento adequado da obra se mostra um dado fundamental para quem busca compreender os eventos insólitos de sua fícção.

Como informa Antônio Candido, o boom editorial ocorrido no Brasil em fins da década de 60 e durante a década de 70 acarretou efeitos diversos tanto em nossa produção literária como também na nossa forma de recepção da literatura. Fortemente vinculado ao meio jornalístico e às suas técnicas de escrita, esse momento de expansão editorial não só manteve uma convivência harmoniosa entre os gêneros literários, mas possibilitou experiências extremas dentro dessas formas:

Não se trata mais de coexistência pacífica das diversas modalidades de romance e de conto, mas do desdobramento destes gêneros, que na verdade deixam de ser gêneros, incorporando técnicas e linguagens nunca dantes imaginados dentro de suas fronteiras. Resultam textos indefiníveis: romances que mais parecem reportagens; contos que não se distinguem de poemas ou crônicas, semeados de sinais e fotomontagens; autobiografias com tonalidade e técnica de romance; narrativas que são cenas de teatro; textos feitos coma justaposição de recortes, documentos, lembranças, reflexões de toda sorte. A ficção recebe na carne mais sensível o impacto do boom jornalístico moderno (...) ${ }^{110}$

Como informa Candido, a voga entre nós, influenciada também pela crítica internacional, da prosa hispano-americana foi outro efeito desse momento editorial, pois

109 PRADO, Antonio Arnoni. Atrás do mágico relance: uma conversa com José J. Veiga. Campinas, Editora da Unicamp, 1989. Coleção Viagens da Voz, p. 33.

110 CANDIDO, Antonio. "A nova narrativa". In: A educação pela noite \& outros ensaios. São Paulo, Ática, 1987, p. 209. 
escritores como Jorge Luís Borges, Julio Cortázar, Gabriel Garcia Marquez, Bioy Casares, Juan Rulfo, Carlos Fuentes, etc., foram conhecidos pelo público brasileiro ou tiveram esse público aumentado significativamente a partir das várias traduções de seus livros no Brasil, algumas delas já em meados da década de 60. Concomitante à chegada das obras, é claro, chegaram até nós também as interpretações que estrangeiros faziam dessa produção literária.

É, então, somente a partir do conhecimento da literatura, classificada genericamente de realismo fantástico ou realismo maravilhoso, que a crítica brasileira, em maior número, vai atentar para muitos escritores. Veja-se o que diz Candido sobre Murilo Rubião:

Com segurança meticulosa e absoluta parcialidade pelo gênero (pois nada escreve fora dele), Murilo Rubião elaborou os seus contos absurdos num momento de predomínio do realismo social, propondo um caminho que poucos identificaram e só mais tarde outros seguiram. Na meia penumbra ficou ele até a reedição modificada e aumentada daquele livro em 1966 (Os dragões e outros contos). Já então a voga de Borges e o começo da de Cortázar, logo seguida pela divulgação no Brasil de livros como Cien años de soledad, de García Márquez, fizeram a crítica e os leitores atentaram para esse local discreto precursor local, que todavia precisou esperar os anos 70 para atingir plenamente o público e ver reconhecida a sua importância." 111

É nesse momento editorial também que se insere a publicação regular das obras de Veiga, o que de certa forma esclarece a sua filiação apressada por parte da crítica e público nas colunas da literatura fantástica, então na moda. O escritor, no entanto, sempre se esquivou dessa classificação argumentando que sua obra se propunha apenas a ser uma

${ }^{111}$ CANDIDO, Antonio. Ob.. Cit., p. 208. 
literatura indagativa, que se perguntasse sobre o mundo, as pessoas, as crises, discutisse o sentido da vida e do mundo, sobretudo dessa parte dele que nos coube habitar. ${ }^{112}$

Ao mesmo tempo em que negava praticar um fantástico segundo uma concepção européia, o escritor admitia a possibilidade de ser visto dessa perspectiva estrangeira como um escritor fantástico, pois

para eles esse nosso lado do mundo é uma surpresa porque eles já se esqueceram o que se passou por lá em outras épocas. Aqui temos leprosos e leprosários, lá isso só existe nas histórias do passado (...) Por isso eles nos olham e pensam que vivemos em um mundo fantástico. ${ }^{113}$

A percepção de que são as diferenças de perspectiva que causam a impressão do fantástico, respalda a afirmação de que, à consciência do escritor, "os conceitos de realidade e de fantástico são relativos, pois depende do lugar (não apenas físico) de que são apreendidos" ${ }^{114}$. Essa noção parece ser transposta integralmente à sua ficção, pois o insólito na literatura de Veiga nasce quase sempre da impotência do sujeito frente a um objeto a que não se tem acesso, um objeto distante da visão e da compreensão do sujeito. As limitações impostas pelo mundo real empurram os personagens dessas estórias para limites oscilantes nos quais o elemento de fantasia procura dar vazão ao impulso de conhecimento das coisas antes represado. Mas quase sempre esse elemento não consegue se desvincular totalmente daquelas limitações impostas pelo mundo real, sendo elas, ao final das contas reproduzidas de maneira quase inexorável no plano da fantasia.

Nesse sentido é que se pode constatar a maciça presença de instantes de vigília, sonho, devaneio, fantasia inventiva e até mesmo loucura nos contos de Os cavalinhos

112 DANTAS, Gregório. José J. Veiga e o romance brasileiro pós-64. Falla dos Pinhaes, Espírito Santo do Pinhal, SP, v.1, n.1, 2004, p. 6.

113 Op. cit., p. 6.

${ }^{114}$ Op. cit., p. 6. 
de Platiplanto e A estranha máquina extraviada, e não só nos contos que possuem como narrador, ou protagonista, personagens infantis ou juvenis, como se pode constatar, por exemplo, num conto instigante como Acidente em Sumaúma. Ao analisar com acuidade esses limites oscilantes do insólito nas narrativas dos dois primeiros livros de contos de Veiga, Agostinho de Souza afirma que "no jogo do espaço e do tempo, as fronteiras entre real/sonho/vigília se transpassam, num processo de interlocução social análogo ao do discurso literário" ${ }^{115}$.

Nesses enredos, portanto, o insólito provém, na maior parte das vezes, do elemento onírico por meio de mecanismos narrativos tradicionais, com se pode perceber em rápidos exemplos: "Uma noite eu acordei cuidando ter ouvido o bater de cascos...", de Invernada do desassossego; "Quando ele abriu os olhos estranhou o tamanho do quarto.”, de Acidente em Sumaúma; "Devo ter caído no sono em algum lugar...”, de Os cavalinhos de Platiplanto; "Quando viu que ia dormir ele pôs a caixa no chão...", de $\mathrm{Na}$ estrada do amanhece. Esses mecanismos narrativos tão comuns na tradição literária são, porém, operados com tal perícia que se elimina as linhas divisórias entre o real e o irreal numa transposição fluida que causa a impressão de uma continuidade insólita ou fantástica para algo que se estava contando de maneira verossímil.

Além desses motivos há um último que também parece ser consistente para justificar a opção de uma leitura de $A$ hora dos ruminantes que não enverede pela natureza do fantástico. É que o surgimento dos bois como um elemento de tal natureza carece de certa ligação orgânica com todo percurso narrativo anterior, ou seja, carece de um significado que impeça a configuração dos animais como um evento abstrato e desvinculado de tudo o que foi antes representado. A impressão que se tem, porém, é que ao buscar um sentido para essa aparição, fatalmente esse movimento leva ao alegórico.

\footnotetext{
${ }^{115}$ SOUZA, A. P. de. Op., cit., pp. 99-100.
} 
Sendo assim, a presente leitura opta por deixar de lado uma interpretação do surgimento dos animais que se baseie no seu provável aspecto fantástico para atentar no caráter alegórico que se julga estar por trás do insólito praticado ali. Obviamente, como a leitura até agora tem se baseado nas características realistas da narrativa, a interpretação do evento dos bois como uma representação alegórica pode soar contraditória, pois como diz Davi Arrigucci Jr., ao tratar dos aspectos alegóricos na literatura brasileira da década de 70 , “O recurso à alegoria é um problema para a fícção que se quer realista”. Essa afirmação é relativizada no decorrer de sua fala, embora o crítico mantenha a formulação lukácsiana sobre alegoria como paradigma da discussão:

A idéia central do Lukács, a respeito da alegoria, é a de que ela corresponde ainda a um impulso religioso na arte. Ao longo da história da arte a alegoria esteve sempre ligada às formas de arte religiosa. E na luta libertadora da arte com relação à religião, na perspectiva do Lukács, a volta à alegoria representa ainda a volta àquele impulso religioso. Só que, na sociedade atual este impulso não se preenche por nenhuma religião institucionalizada. Ou seja, a alegoria moderna corresponde a um a posição niilista, no fundo a um individualismo anárquico e niilista. É um sentimento religioso que não se preenche, então há uma espécie de transcendência vazia na alegoria. O verdadeiro conteúdo alegórico é o nada, na visão lukácsiana. Como tudo alude a tudo o objeto dessa coisa é um fundo perdido, que não se preenche nunca. Não creio que o fato de ser alegórico condene qualquer arte. O que eu noto é o seguinte: no impulso realista, o procedimento alegórico é problemático. Se eu construo de acordo com a ficção realista, eu tenho dificuldades para tratar de forma alegórica. A não ser passagens alegóricas. ${ }^{116}$ (itálico meu)

Diferente conceito tem Walter Benjamin para quem "a alegoria não é frívola técnica de ilustração por imagens, mas expressão, como a linguagem, e como a

116 ARRIGUCCI JR., Davi. "Jornal, realismo e alegoria: romance brasileiro recente". In Ficção em debate e outros temas. São Paulo, Duas Cidades; Unicamp, 1979, p. 31. 
escrita." "117 Salvo engano, o que Lukács supõe uma forma vazia e estéril é vista pelo filósofo alemão como a construção de uma figura, concentrada de significado, capaz de expor a face de morte da História "como proto-paisagem petrificada".

Ao passo que no símbolo, com a transfiguração do declínio, o rosto metamorfoseado da natureza se revela fugazmente à luz da salvação, a alegoria mostra ao observador a facies hippocratica [face de morte] da história como proto-paisagem petrificada. A história em tudo o que nela desde o início é prematuro, sofrido e malogrado, se exprime num rosto - não numa caveira. E porque não existe, nela, nenhuma harmonia clássica da forma, em suma, nada de humano, essa figura, de todas a mais sujeita à natureza, exprime, não somente a existência humana em geral, mas, de modo altamente expressivo, e sob a forma de um enigma, a história biográfica de um indivíduo. Nisso consiste o cerne da visão alegórica: a exposição (...) mundana da história como história mundial do sofrimento, significativa apenas nos episódios do declínio. Quanto maior a significação, tanto maior a sujeição à morte, porque é a morte que grava mais profundamente a tortuosa linha de demarcação entre a physis [natureza física] e a significação. ${ }^{118}$

A pertinência de uma leitura da obra de Veiga que considera o caráter alegórico segundo uma conceituação benjaminiana já foi identificada, por exemplo, num estudo de 1990 da Universidade Federal do Rio de Janeiro, elogiado pelo próprio Veiga. Em ensaio retirado desse estudo Iza Quelhas afirma que Benjamin identifica

a alegoria moderna na ruptura entre a experiência e a tradição, o que sinaliza as relações sociais fragmentadas num mundo hostil, que impossibilita o estabelecimento de elos entre o fazer e o pensar, entre a ação e a reflexão, a tradição e a mudança. Assim a alegoria como constituinte do texto literário, produz na literatura veiguiana uma ambiência de encantamento, de um conto de fadas às avessas. ${ }^{119}$

117 BENJAMIN, W. Origem do drama barroco alemão. Tradução, apresentação e notas de Sérgio Paulo Rouanet. São Paulo, Brasiliense, 1984, p.

118 Op. cit., p. 188.

${ }^{119}$ QUELHAS, I. T. G. "No país do faz de contas: uma leitura da obra de José J. Veiga". In: Recorte - Revista de Linguagem, Cultura e Discurso, Três Corações - MG, UNINCOR, nº 3, p. 4, 2005. 
A hora dos ruminantes é aqui interpretada como uma narrativa realista que se utiliza, principalmente na última parte, do recurso alegórico, dentro das possibilidades que a ficção contemporânea oferece, para a configuração de um momento histórico particular que para ser dito da maneira como de fato ocorreu carece, como disse Adorno, "renunciar a um realismo que na medida em que reproduz a fachada, apenas a auxilia na produção do engodo." ${ }^{120}$ Isso porque a representação de uma realidade local, precária e ambígua mediante tratamento realista convencional estaria sobre um fio de navalha, sobre uma linha tênue cujo outro lado seria a reprodução de clichês, de estereótipos, de esquematismos e exotismos.

Além disso, a opção pelo alegórico e não pelo fantástico acabaria, talvez, justificando a possibilidade de perceber a escrita de Veiga inserida naquele terceiro momento do regionalismo que Antonio Candido reclama com o nome de superregionalismo (ou supra-regionalismo), tendo como exemplo maior a obra singular de Guimarães Rosa; essa fase, para o crítico, corresponderia ao momento de "consciência dilacerada do subdesenvolvimento":

O que vemos agora (...) é uma florada novelística marcada pelo refinamento técnico, graças ao qual as regiões se transfiguram e os seus contornos humanos se subvertem, levando os traços antes pitorescos a se descarnarem e adquirirem universalidade.

Descartando o sentimentalismo e a retórica; nutrida de elementos não-realistas (...) ou de técnicas antinaturalistas (...) ela implica não obstante em aproveitamento do que antes era a própria substância do nativismo, do exotismo e do documento social. Isso levaria a propor a distinção de uma terceira fase, que se poderia (pensando em surrealismo, ou super-realismo) chamar de super-regionalista. Ela corresponde à consciência dilacerada do subdesenvolvimento e opera uma explosão do tipo de naturalismo que foi a

${ }^{120}$ ADORNO, Theodor. W. "A posição do narrador no romance contemporâneo". In Notas de Literatura I. Tradução e apresentação de Jorge de Almeida. São Paulo, Duas Cidades; Ed. 34, 2003, p. 57. 
tendência estética peculiar a uma época onde triunfava a mentalidade burguesa e correspondia à consolidação das nossas literaturas. ${ }^{121}$

O aparecimento incompreensível dos bois, dentro desse nexo, seria a representação da dissociação entre homem e natureza, os animais multiplicados numa mancha compacta como arruinamento dessa relação. Eles seriam a representação da perda de correspondência com o meio natural, perda de uma ordem até então percebida como a ordem natural das coisas e que agora é revirada e representada através de uma imagem que torna ambíguo o que antes era certo - o boi animal vital como animal mortal - e que em função dessa ambigüidade realiza uma justa aproximação desse sentimento de descompasso e hostilidade do mundo natural.

É possível, no entanto, que a partida dos bois no final da estória leve a pensar numa contradição entre essa leitura e a permanência do povoado de Manarairema, mas essa possível contradição pode ser desfeita a partir da interpretação da invasão dos bois como um divisor de épocas na evolução daquela comunidade. Os bois prenunciam uma reconfiguração do mundo, são, portanto, um aviso, uma mensagem, uma escrita, morte e renascimento simultaneamente.

Após a partida dos bois, a cidade amanhece com uma camada espessa de esterco sob uma "chuva paulina":

O dia seguinte amanheceu chuvoso, uma chuvinha de peneira fina (...) dando à paisagem uma feição de mundo nascente, bezerro, recémlambido, ainda molhado da língua materna. ${ }^{122}$

O mundo continua, assim como continua a incapacidade dos manarairenses e, talvez, do narrador de perceber amplamente a ocorrência do movimento de mudança.

${ }^{121}$ CANDIDO, Antonio. "Literatura e subdesenvolvimento". In: A educação pela noite \& outros ensaios. São Paulo, Ática, 1987, p. 161.

${ }_{122}$ VEIGA, J. J. Op. cit., p. 97. 
Após o susto do emparedamento, os personagens todos (à exceção de Apolinário) comemoram com alegria e alívio, é claro, a partida dos animais. No entanto, não há indícios de qualquer busca de compreensão do que ocorrera, nenhuma ação de procura de respostas, as pessoas parecem retornar à vida cotidiana sem reparar a sombra maior que chegara sobre as ruínas de Manarairema.

Uma vez mais o ponto de vista do narrador, compartilhando a limitação do horizonte dos manarairenses, e com isso interferindo na relação de causalidade dos eventos, incomoda o leitor cuja posição privilegiada já possibilitara a percepção do movimento de transformação que atinge o lugar. No entanto, apesar do incômodo do leitor, o procedimento atenta à lógica interna da composição, ao mesmo tempo em que continua contemplando uma verdade histórica, a falta de compreensão, por parte do povo, dos movimentos de uma macro realidade em que está inserido inconscientemente e no qual possui papel de espectador ou de coisa a ser usada.

Antes de finalizar é necessário comentar um aspecto da trama que nem sempre é devidamente percebido nas abordagens da obra, ou quando é percebido nem sempre o é com o significado que parece ter. Na cena final da estória Geminiano Dias aparece vindo do acampamento com a carroça cheia de utensílios. Tendo readquirido sua espontaneidade anterior o carroceiro tenta entabular uma conversa com seus interlocutores ressabiados. Fica-se, então, sabendo que os forasteiros partiram, notícia surpreendente para os moradores que procuram saber o motivo:

- (...) Andavam muito assustados.

- Medo de quê?

- Sei lá. De tudo. De nós. Quero dizer, de vocês.

A informação de Geminiano parece dizer algo significativo: pela resposta percebe-se que enquanto se pensava que os bois eram regulados pelas intenções dos 
forasteiros - como ocorre no caso dos cachorros -, os forasteiros por sua vez acreditavam serem os manarairenses os responsáveis por tal desatino, demonstrando com isso, mais uma vez, seu caráter tacanho e limitado frente ao mundo que se descortina. Portanto, os animais surgem e se vão à revelia dos forasteiros, embora estes, com sua presença alterando todas as relações daquele mundo, sejam em última instância os responsáveis pelo descontrole das coisas.

Essa limitação dos estranhos, inclusive, se mostra até maior do que a dos manarairenses na medida em que sugere uma forte dose de alienação ocupando o espaço entre suas ações e o que elas ocasionam. Ao dizer que os homens haviam fugido com medo da população, Geminiano explicita para todos aquilo que antes só Apolinário soubera: que os forasteiros eram pessoas tão comuns quanto a gente de Manarairema, possuíam a mesma dificuldade de entendimento, a mesma dificuldade com a palavra, o mesmo pensamento procurando respostas invisíveis.

Ainda um detalhe: no diálogo com os conterrâneos Geminiano tenta reatar os antigos códigos sociais de relacionamento e para isso instiga os interlocutores a irem ao acampamento resgatar galinhas e porcos que lá ficaram. Ironicamente o único que se anima é Amâncio Mendes, mas logo contém o entusiasmo através de uma frase cheia de significados, com referências evidentes às invasões sofridas, mas possível de ser lida como um desmascaramento irônico por parte do narrador, do jogo convencional da literatura: “- Vamos deixar os bichos em paz (...) Galinha no mato tem muita defesa. E porco vira catetu." 123

O parágrafo final aponta para um reinício do tempo e a narrativa encerra-se na perspectiva da história como natureza onde reina o destino indecifrável:

${ }^{123}$ Op. cit., p. 102. 
$\mathrm{O}$ relógio da igreja rangeu as engrenagens, bateu horas, lerdo desregulado. Já estavam erguendo o peso, acertando os ponteiros. As horas voltavam, todas elas, as boas, as más, como deve ser. ${ }^{124}$

Apesar das prováveis falhas do livro, a obra é significativa na medida em que procura com perspicácia e senso estético figurar um momento muito particular no desenvolvimento social do país: o contato de distantes comunidades sertanejas do Centro-Oeste com uma forma de vida que iria em pouco tempo suplantá-las. Na mesma proporção em que essa nova forma de vida se mostra de maneira estranha, desfocada, ininteligível àqueles povos, a narrativa traz para a própria forma a percepção desse insólito.

Nesse sentido é possível dizer que as obras principais de Veiga, os três primeiros livros do escritor, são as produções mais emblemáticas na representação desse momento significativo na história do país, a ocupação do Centro-Oeste a partir do início do projeto Brasília, na medida em que autores como Mário Palmério ou Bernardo Élis, já na década de 50 mantinham-se atrelados a um tratamento realista/naturalista nos moldes do romance social de 30 , enquanto que Veiga percebe a necessidade, principalmente após o evento Guimarães Rosa, de quem era amigo e leitor privilegiado, de se dar um passo adiante na configuração dessa mudança social. Por trás dessa necessidade sentida pelo autor, percebe-se nitidamente e mais uma vez - como característica pulsante de nossa produção literária - a utilização da literatura como um instrumento de descoberta e interpretação contínua do país. 
BIBLIOGRAFIA

Obras de José J. Veiga 
Os Cavalinhos de Platiplanto. $15^{\mathrm{a}}$ ed., São Paulo, DIFEL, 1985. (1ª edição: Rio de Janeiro, Nítida, 1959.)

A hora dos ruminantes. 28 ${ }^{\mathrm{a}}$ ed., Rio de Janeiro, Bertrand Brasil, 1993. (1 edição: Rio de Janeiro, Civilização Brasileira, 1966.)

A estranha máquina extraviada. $4^{\mathrm{a}}$ ed., Rio de Janeiro, Civilização Brasileira, 1981. (1 $1^{a}$ edição: A máquina extraviada. Rio de Janeiro, Prelo, 1968.)

Sombra de reis barbudos. $13^{\mathrm{a}}$ ed., São Paulo, Bertrand Brasil, 1987. (1ª edição:

Rio de Janeiro, Civilização Brasileira, 1972.)

Os pecados da tribo. Rio de Janeiro, Civilização Brasileira, 1976.

De jogos e festas. Rio de Janeiro, Civilização Brasileira, 1980.

O professor Burrim e as quatro calamidades. Belo Horizonte, Comunicação, 1980. (infanto-juvenil)

Aquele mundo de Vasabarros. São Paulo, DIFEL, 1982.

Torvelinho dia e noite. São Paulo, DIFEL, 1985.

Tajá e sua gente. Rio de Janeiro, Salamandra, 1986. (infanto-juvenil)

O almanach de Piumhy. Rio de Janeiro, Record, 1988.

A casca da serpente. Rio de Janeiro, Bertrand Brasil, 1989.

O risonho cavalo do príncipe. Rio de Janeiro, Bertrand Brasil, 1994.

O relógio Belisário. Rio de Janeiro, Bertrand Brasil, 1995.

Objetos turbulentos. Rio de Janeiro, Bertrand Brasil, 1997.

\section{Obras sobre José J. Veiga}

CASTELO, José. “José J. Veiga trabalha nos limites da fantasia”. In O Estado de São Paulo, 04/10/97.

CAMPEDELLI, Samira Y. José J. Veiga. São Paulo, Abril Cultural, 1982.

LABOISSIÈRE, $\mathrm{M}^{\mathrm{a}}$ Luiza Ferreira. A transfiguração da realidade em José J. Veiga e Miguel Jorge. Goiânia, Secretaria de Cultura do Estado, 1989.

MIYAZAKI, Tieko Y. José J. Veiga: de Platiplanto a Torvelinho. São Paulo, Atual, 1988.

PRADO, Antonio Arnoni. Atrás do mágico relance: uma conversa com José J. Veiga. Campinas, Editora da Unicamp, 1989.

PÓLVORA, Hélio. “A arte da levitação no mágico José J. Veiga”. In: Jornal do Brasil, Rio de Janeiro, 27/05/72. 
RANGEL, Carlos. "José J. Veiga, escritor brasileiro". In: Revista Escrita, nº 1, São Paulo, Vertente, 1975.

RIBEIRO, Leo Gilson. “E nós seremos uma tribo. De selvagens.” In: Jornal da Tarde, São Paulo, 18/09/72.

SOUZA, Agostinho Potenciano de. Um olhar crítico sobre o nosso tempo: uma leitura da obra de José J. Veiga. Campinas, Editora da Unicamp, 1990.

QUELHAS, I. T. G. "No país do faz de contas: uma leitura da obra de José J. Veiga". In: Recorte - Revista de Linguagem, Cultura e Discurso, UNINCOR, Três Corações - Minas Gerais, v. 3, p. 1-8, 2005. www.weblivros.com.br (site com a última entrevista de José J. Veiga)

\section{Obras sobre narrativa brasileira contemporânea}

ARRIGUCCI JR., Davi. "Jornal, realismo e alegoria: romance brasileiro recente". In: Ficção em debate e outros temas. São Paulo, Duas Cidades; Unicamp, 1979.

BOSI, Alfredo. "Situação e formas do conto brasileiro contemporâneo". In: (org.) O conto brasileiro contemporâneo. $3^{\mathrm{a}}$ ed., São Paulo, Cultrix, 1978.

CANDIDO, Antonio. "A nova narrativa". A educação pela noite \& outros ensaios. São Paulo, Ática, 1987.

. "Pretensão sem surpresa”. In: Livros na mesa: estudos de crítica. Rio de Janeiro, São José, 1960.

HOHLFELDT, Antonio. O conto brasileiro contemporâneo. Porto Alegre, Mercado Aberto, 1981.

LIDMILOVÁ, Pavla. Alguns temas da literatura brasileira. Rio de Janeiro, Nórdica/INL, 1984.

LINHARES, Temístocles. 22 diálogos sobre o conto brasileiro atual. Rio de Janeiro, José Olympio, 1973.

LUCAS, Fábio. Razão e emoção literária. São Paulo, Duas Cidades, 1982. . Vanguarda, história e ideologia da literatura. São Paulo, Ícone, 1985.

OTSUKA, Edu Teruki. Marcas da catástrofe: experiência urbana e indústria cultural em Rubem Fonseca, João G. Nöll e Chico Buarque. São Paulo, Nankin, 2001. 
SCHWARZ, Roberto. "Um romance de Chico Buarque". In: Seqüências Brasileiras. São Paulo, Companhia das Letras, 1999.

VIDAL, Ariovaldo José. Roteiro para um narrador. Uma leitura dos contos de Rubem Fonseca. Cotia, Ateliê Editorial, 2000.

SILVERMAN, Malcolm. Moderna Ficção Brasileira. Rio de Janeiro, Civilização Brasileira/MEC, 1978.

\section{Bibliografia Geral}

ALMEIDA, Jorge. "Hermetismo \& Alienação. Considerações sobre 'Uma visita à mina' de Franz Kafka”. In: Revista Magma, no 1, São Paulo, DTLLC/FFLCH/USP, 1994.

ADORNO, Theodor. W. Notas de Literatura I. Tradução e apresentação de Jorge de Almeida. São Paulo, Duas Cidades; Ed. 34, 2003. . Prismas: crítica cultural e sociedade. Trad. Augustin Wernet e Jorge de Almeida. São Paulo, Ática, 2001.

e outros. Textos escolhidos. Trad. Modesto Carone e outros. $2^{\mathrm{a}}$ ed., São Paulo, Abril Cultural, 1983, col. Os Pensadores.

ARRIGUCCI JR., Davi. “Achados e perdidos. São Paulo, Polis, 1979.

BENJAMIN, Walter. Obras escolhidas I: Magia e técnica, arte e politica. Trad. Sérgio Paulo Rouanet. São Paulo, Brasiliense, 1985. . Origem do drama barroco alemão. Tradução, apresentação e notas de Sérgio Paulo Rouanet. São Paulo, Brasiliense, 1984. e outros. Textos escolhidos. Trad. Modesto Carone e outros. $2^{\mathrm{a}}$ ed., São Paulo, Abril Cultural, 1983, col. Os Pensadores.

BOSI, Alfredo. Céu, inferno: ensaios de crítica literária e ideológica. São Paulo, Ática, 1988. . Reflexões sobre a arte. $2^{\mathrm{a}}$ ed., São Paulo, Ática, 1986.

BRAIT, Beth. A personagem. $3^{\text {a }}$ ed., São Paulo, Ática, 1987.

CANDIDO, Antonio. A educação pela noite \& outros ensaios. São Paulo, Ática, 1987. e outros. A personagem de ficção. $7^{\mathrm{a}}$ ed., São Paulo, Perspectiva, 1985. . Formação da Literatura Brasileira (momentos decisivos). $2^{\mathrm{a}}$ ed., 2 v., . Literatura e sociedade. $4^{\mathrm{a}}$ ed., São Paulo, Nacional, 1975.

São Paulo, Martins, 1964 
CARPEAUX, Otto Maria. História da Literatura Ocidental. $2^{\mathrm{a}}$ ed., Rio de Janeiro, Alhambra, 1982, vol. 6.

COUTINHO, Carlos Nelson. Lukács, Proust e Kafka: literatura e sociedade no século XX. Rio de Janeiro, Civilização Brasileira, 2005.

. Literatura e Humanismo. Ensaios de crítica marxista. Rio de Janeiro, Paz e Terra, 1967.

DIMAS, Antonio. Espaço e romance. $2^{\mathrm{a}}$ ed., São Paulo, Ática, 1987.

HANSEN, João Adolfo. Alegoria: construção e interpretação da metáfora. São Paulo, Atual, 1986.

HOLANDA, Sérgio Buarque de. Raízes do Brasil. $7^{\text {a }}$ ed., Rio de Janeiro, José Olympio, 1973.

LUKÁCS, Georg. Introdução a uma estética marxista. Rio de Janeiro, Civilização Brasileira, 1970. . Marxismo e teoria da literatura. Rio de Janeiro, Civilização Brasileira, 1968.

. Teoria do Romance. Trad. Alfredo Margarido. Lisboa, Presença, s.d.

MEYER, Augusto. À sombra da estante. Rio de Janeiro, José Olympio, 1947.

PAES, José Paulo (Org., trad. e introdução). Os buracos da máscara: antologia de contos fantásticos. São Paulo, Brasiliense, 1985.

POE, Edgar A. Poesia e prosa. Trad. Oscar Mendes. Rio de Janeiro, Ediouro, s.d.

REUTER, Yves. Introdução à análise do romance. Trad. Ângela Bergamini e outros. São Paulo, Martins Fontes, 1996.

RIBON, Michael. A arte e a natureza. Trad. Tânia Pellegrini. São Paulo, Papirus, 1991.

ROSENFELD, Anatol. Texto/Contexto I. $5^{\text {a }}$ ed., São Paulo, Perspectiva, 1996.

SCHWARZ, Roberto. Cultura e política. $2^{\mathrm{a}}$ ed., São Paulo, Paz e Terra, 2005.

TOLEDO, Dionísio de Oliveira (org). Teoria da Literatura: Formalistas Russos. Trad. Ana Mariza Ribeiro e outros. Porto Alegre, Globo, 1971.

VIDAL, Ariovaldo José. "Sobre um conto de Kafka". In Revista Magma, nº1, São Paulo, DTLLC/FFLCH/USP, 1994.

WATT, Ian. A ascensão do Romance. Trad. Hildegard Feist. São Paulo, Companhia das Letras, 1990. 
